CHAPTER 14

\title{
'Ex Musaeo et Impensis Jacobi Stradae, S.C.M. Antiquarius, Civis Romani': Strada's Frustrated Ambitions as a Publisher
}

\subsection{Is There Life Beyond the Court?}

One of the principal purposes of this study is better to understand the nature of Strada's function at court, as an indispensable condition to appreciate the significance of his presence for Imperial intellectual and artistic patronage and, more in general, for the cultural history in the Habsburg territories and Southern Germany. For that reason the greater part of the preceding chapters has been devoted to Strada's coming to the Vienna court and his subsequent employment in Imperial service. Even within the context of his career as a whole, such ample attention is warranted by the length of Strada's employment, the importance of his patrons, and the value he himself attached to his status as an Imperial servant and courtier. Nevertheless neither Strada's usefulness for Ferdinand I and Maximilian II and the character of the return they expected from his presence at court, nor Strada's view of his chosen profession can be explained without reference to the activities he engaged in independently from his work at court. His occupations before he came to Vienna have been described in my earlier chapters. Before discussing the activities he undertook simultaneously but quite separately from his tasks at court and after his resignation, it is useful briefly to sketch his private circumstances, with a view of the role his family played in his professional life.

\subsection{Strada's Family}

Shortly after his first contacts with Ferdinand I Strada came to Vienna, apparently ready to settle at court, because he had brought his wife and household. ${ }^{1}$ By that time his family consisted of his wife, Ottilie Schenk von Rossberg, his sons Paolo (Nuremberg 1548) and Ottavio (Nuremberg 1550) and doubtless also at least the daughter on the occasion of whose wedding in 1569 Maximilian I I accorded Strada a gift of $5^{0}$ Gulden. Apart from her name we know hardly

1 Doc 1558-06-11, cited in Ch. 4.2.2. 
anything about Strada's wife, but she must have had certain talents, if Strada could leave his house and affairs in her hands during his frequent and long absences. ${ }^{2}$ Strada's consciously stoic report to his old friend Jacopo Dani of her death in September 1574 suggests a basically happy marriage:

\begin{abstract}
Last week I had a most welcome letter from Your Honour, to which I have not responded at once as was my intention, because my wife suffered from such a grave illness of the chest, that in the five days that she was in bed the doctors have never been able to help her; and thus she has passed to a better life. May the Lord have her soul. We have been together for thirty years; there has never been a quarrel between us, nor even an impatient word. ${ }^{3}$
\end{abstract}

From Strada's letter to Adam von Dietrichstein of March 1566 we know that by that time the couple had seven children living. ${ }^{4}$ Strada's will of July 1584 shows that four of these reached maturity, the two sons Paolo and Ottavio mentioned, and two daughters, Anna and Lavina. Anna had married Steffan Präussen and had had two daughters, but she herself had died by the time Strada dictated his will, and her two girls both had already taken monastic vows. Doubtless she had been given a dowry of 400 Gulden, as had her sister Lavina (or Lavia), who in 1584 was the widow of Ferdinand Luzenburger or Lützelburger. ${ }^{5}$ The existence of a daughter Katharina who would have been Rudolf II's

2 On Ottilie Schenk von Rossberg's family, see above, Ch. 2.4.

3 Doc 1574-09-09: 'La settimana passata hebbi una della Signoria Vostra gratissima, et non gli rispose al'hora come era l'animo mio, per causa di una gravissima infirmità della punta che travagliava mia moglie, che in cinque giorni ch'è stata nel letto mai li medici l'anno potuto aiutare, et cossì è passata a meglior vitta. Il Signor Iddio habbi l'anima sua. Siamo stati 30 anni insieme, mai ci fu querella fra di noi, ne una mala parola hor patienza'. Both Maximilian and Rudolf sent their gentlemen of the chamber to attend her funeral, 'et vi era un monte di signori', confirming both her own status and that of her husband (Doc 1576-09-28).

4 Doc 1566-03-01: 'Vostra Signoria Illustrissima sappia che adesso son più povero che mai sia per lo avanti stato, e più carico di spesa che prima, perchè mi truovo vii figlioli vivi....'

5 Doc 1584-07-01. The Lützelburger were probably close associates of the Stradas: it seems likely that the 'Barbara von Luxemburg', widow of one 'dr Adam', whom Ottavio married in 1583, was a relative of Ferdinand Lützelburger, perhaps his sister. In the eighteenth century this name made their French descendants boast of two Imperial Bohemian connections: not only with Rudolf, but also with the house of Luxemburg. Possibly the Lützelburger were Nuremberg patricians, business relations of the elder Strada with whom he had remained in contact; perhaps they were descendants of the Basle wood engraver Hans (Franck) Lützelburger $(\dagger 1526)$, responsible for the blocks of Holbein's Dance of Death. On the other hand it cannot be excluded that they were members of the noble family resident in Saxony and Lusatia, which furnished officials to several Austrian Archdukes (Kneschke 1865, pp. 52-53). 
mistress is a misapprehension of Svátek which needs to be corrected again and again. ${ }^{6}$

Some years after his wife's death, perhaps on his trip to the Elector August of Saxony in the autumn of 1576, Strada began a liaison with Margaretha Hummer or Himmer, from Marienberg in the Margraviate of Meissen, whom he describes in his will both as his 'Dienerin' - his servant—and his 'concubine'. In 1582 Rudolf II had legitimized the two sons she gave him, Tobia, born in 1578, and Martino, born in 1580. Martino appears to have died soon after, since he is not mentioned in Strada's will, but his sister Sicilia survived and was promised a legacy of hundred Gulden. Whereas their mother had to be content with her outstanding wages, a third of the revenue of Strada's various houses and gardens was assigned to Tobia's maintenance and education, and he was allotted a decent share in his father's inheritance. Moreover his father appointed curators expected to manage his patrimony until his majority and 'to raise him to diligent study, gravity and the fear of God. ${ }^{7}$

Strada doubtless had taken equal care of the education of his legitimate male offspring, who were taught in the Vienna Jesuit College, founded by Peter Canisius in $155^{2}$ in response to Ferdinand I's request to Ignatius of Loyola. ${ }^{8}$

6 Svatek 1883; Svatek 1891-1892; cf. Ch. 0.1. In fact Rudolf II's mistress was Anna Maria Strada (1579-1629), the natural daughter of Ottavio Strada and one Mariana Hofmaisterin, according to his testament of 26 February 1606 [HHStA, Obersthofmarschallamt, Karton 624, Konvolut 1606/1]. She was the mother of two of Rudolf's illegitimate but recognized sons, Mathias and Carolus Faustus (but not of his favourite son Julius, who would become insane and is the subject of many legends and romantic tales). This is clear from the documents relating to Don Mathias of Austria in the Vienna Hofkammerarchiv, Hoffinanz, r., nr. 185, '1622, Jan. 18' ('Konvolut Don Mathias'). I am grateful to Hofrat Dr Christian Sapper who discovered and shared these documents with me at the time; see now his exhaustive study on Rudolf's children, which includes brief essays on the Strada family and Anna Maria's husband, Christoph Ranfft von Wiesenthal (Sapper 1999, pp. 30-44). They are corroborated by Ottavio Strada himself in the entry of Rudolf II in his ms. Chronica thesauri antiquitatum (Prague, University Library, cod. XI.D.20), p. lviii), which gives a survey of Rudolf's children from various mothers, of whom only Anna Maria Strada is mentioned by name. Her marriage to Christoph Ranfft is evident both from the 'Konvolut Don Mathias' and from Ottavio's will (cf. Jansen 1988, p. 132 and 143, n. 5). Much later, when already resident in France for many years, Ottavio Strada the Younger still kept in touch with his half-sister and her family, witness a letter by Ranfft to his brother-in-law of 1629 (Vienna, HHStA, RHR, Privilegia Varii Generis 1/10, fol. 80-87).

7 Doc 1584-07-01; Lietzmann 1997, pp. 391-392 suggests that Strada met Margaretha in Meissen on his way back to Vienna from Dresden; Doc 1582-00-oo. Tobia was perhaps still alive when his brother Ottavio made his testament on 25 February 1605, though he had not kept in touch: 'Meinem unehlichen Bruder Tobiam verschaf ich 30 L. wan er noch lebt'. [HHStA, Obersthofmarschallamt, Karton 624, Konvolut 1606/1].

8 'In casa delli Jesuiti ò tenuto in donzina alle spese in compagnia d'altri gentilhuomini gli miei figliuoli'. (Strada to Jacopo Dani, Doc 1576-09-28). 

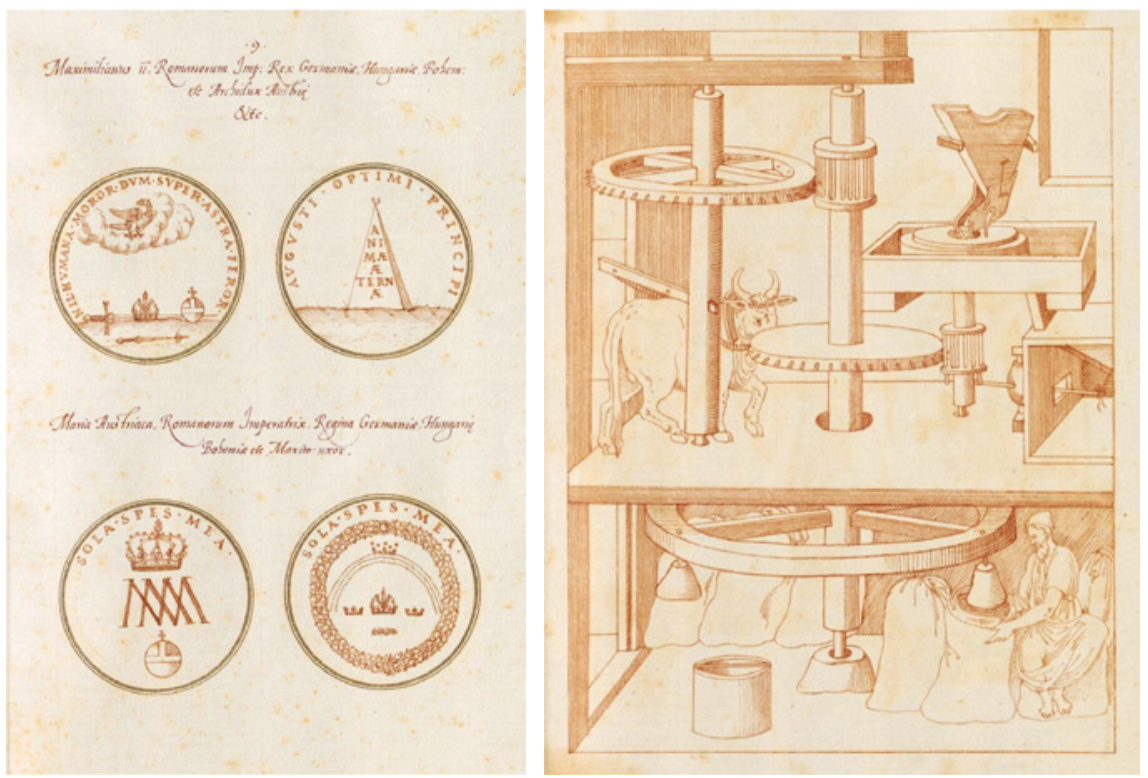

FIGURE 14.1 Ottavio Strada, Emblems of Emperor Maximilian II and Empress Maria, drawings in pen and coloured inks in his ms. Simbola Romanorum imperatorum, Cambridge (Mass.), Houghton Library.

FIGURE 14.2 Ottavio Strada, Design for a treadmill for grinding corn, drawing in pen and ink in his ms. Variae ac faciles molendina construendi inventiones; Munich, Bayerische Staatsbibliothek.

By the time they were adolescents their father took great pains to obtain some secure basic income for them, in the form of an ecclesiastical benefice or a secular sinecure. Thanks to Maximilian's explicit recommendation to Duke Guglielmo Gonzaga, the eldest, Paolo, was elected a canon of Mantua Cathedral. ${ }^{9}$ When their education was complete both Paolo and Ottavio served as gentlemen of the chamber to Archduke Ernest and to King Rudolf respectively. ${ }^{10}$ But both sons were also trained by their father himself, who

9 The success of Strada's attempt to obtain a benefice in Mantua cathedral for his son Paolo was doubtless due to Maximilian II's strong support (Docs. 1565-05-12,1565-05-15; 1565-10-15; 1565-10-23; 1567-03-19; 1567-03-24; 1567-03-25; 1567-06-11; 1568-12-05; 1568-12-28). About the same time Strada attempted to obtain a benefice in Antwerp for one of his sons from Philip II, probably in return for the numismatic manuscript he had presented to the king; but when this turned out to be impossible he opted for a 'pensione' in Milan, and showing a quite pragmatic attitude: 'Io non domando più cosa di chiesa, ma una pensione; io non dessidero già cosa grande, perchè domandandola mi fosse negata, ne anche tanto basso che non meritasse la spesa di averla domandata'. (Strada to Dietrichstein, Doc. 1566-03-01). 'Et alla Signoria Vostra io con li mei figliuoli salutiamo Vostra Signoria per sempre. Ottavio sta con Sua Maestà Cesarea et Pauolo con l'Arciducha Hernest, si che tutti doi sono 
coached them in developing the humanist handwriting so important in his profession. True to the convictions he had expressed in his letter to Adam von Dietrichstein discussed in the preceding chapter, he also carefully taught them to draw: in Ottavio's case with conspicuous success, witness the many elegant illustrated manuscripts he later presented to his many patrons [Figs. 14.1-14.2].11

Having obtained his benefice in Mantua cathedral Paolo Strada appears to have taken holy orders, and to have led a simple, withdrawn life in Vienna. To finish his education and to extend his accomplishments his father sent him with the Imperial embassy led by Karel Rijm to Constantinople, where he was expected to learn Turkish and Arabic, as well as to obtain materials relating to his father's various projects. ${ }^{12}$ On his return in 1573 Strada applied to Maximilian II to have him employed at court, giving a succinct account of his character and accomplishments:

He is inclined to travel, and particularly in Turkey, of which he has some beginning of the language, and in practising it in the future he could completely master it. He is a spirited young man, who will go to the end of the earth if Your Majesty would order him to; he is twenty-five years old, born of a German mother at Nuremberg. He speaks Italian and

ancora servidori della Signoria Vostra, et io insieme'. (Strada to Jacopo Dani, Doc. 157710-04); 'Hora, Signor mio Carissimo, il gentilhuomo, il Signor Riccardo Riccardi io non l'ò visto, ma bene io ne feci cercare per Pauolo mio figliuolo (che hora egli serve qui l'Altezza del Arciducha Hernest con doi cavalli per gentill' huomo), et lui in mio nome lo invitò a vedere il mio studio'. (Strada to Jacopo Dani, Doc. 1582-11-02).

11 Drawings certainly attributable to Paolo Strada have not (yet) been identified.

12 Doc. 1569-11-05, Strada to Guglielmo, Duke of Mantua, Vienna, 5 November 1569: 'Il mio figliolo maggiore mando in Turchia con il Signor ambassador di Sua Maestà, dove starà qualche anno. Se in detto loco potra servire Vostra Excellenzia, lo faro con tutto il cuore et a me sarra summo favore che li comandi. Sua Maestà lo à pigliato in protetione, che come suo creado li sia raccomandato.'; Doc. 1571-11-20, Strada to Guglielmo, Duke of Mantua, Vienna, 20 November 1571: 'Mio figliolo il Canonico Sua Maestà Cesarea lo mantiene in Constantinopoli a imparare la lingua turca et araba; et quelli che vengono di là fanno fede a Sua Maestà Cesarea che fara bonissima riesita, e di già parla turcho comodamente. A mandato di qua la prima parte di Terentio scritto di sua mane-che à studiato in lingua turcha-scritto; et per quest'altra posta mandara il resto; io lo voglio poi presentare a Sua Maestà Cesarea. Esso mi scrive che dessidera servire in detto loco l'Excellenza Vostra Illustrissima in qualche cosa se gli'è buono. Me à anche mandato tutti gl'inventarii del<li> libri graeci che sonno in tutte quelle librarie graeche di Constantinopoli; delli quali creddo se ne averia bonissima conditione quando si volessero comprare, e quando fossero in queste bande saria un thesoro.'; Doc. 1573-06-17, Strada to Jacopo Dani, Vienna, 17 June 1573: 'In Constantinopoli da Pauolo mio figliuolo me ò fatto portare tutti gli Imperatori orientali, o in medaglie o in pittura che à pottuti trovare; et in spatio di 3 anni che vi è stato ne à fatto buona diligenza'. 
Latin; he is a youth ready to bear fatigue and will readily exert himself, if he is asked to. ${ }^{13}$

The latter phrase seems to indicate some lack of initiative on Paolo's part, something of which Ottavio certainly cannot be accused. It is clear that Strada's younger surviving son was a most promising youngster, who shared his father's interests, and like him was endowed with both intellectual and artistic talents. It was Ottavio who was carefully trained by his father as his successor and who at an early age accompanied him as his assistant. Swelling his father's suite of personal servants and local brokers and appraisers, his presence in Venice attracted the invidious attention of Strada's rival, Niccolò Stopio:

[Strada] went around here in Venice $<$... $>$ with scarlet hose, with his son as a page and three or four of these brokers as followers so that he seemed a great lord, but I assure your Lordship that people here don't appreciate such conduct ... ${ }^{14}$

Stopio also refers to what must have been an important function of both Paolo and Ottavio, that is to translate and write their father's letters in German: born of a German mother and bred in Nuremberg and Vienna, their command of the written language was obviously far superior to that of their father and, once old enough, one or both of them habitually functioned as their father's German secretary. ${ }^{15}$

13 Doc. 1573-00-oo: Strada to Maximilian II, without place and date: 'Mi trovo mio figliuolo Pauolo Strada, il quale è sta[to] in Turchia tre anni, nel qual luogo à patito del male assai, come è noto a molti. Io con esso lui suplichiamo la Maestà Vostra Cesarea che li voglia esser raccomandato di un picciol servicio da gentilhuomo, o apresso alla Maestà Vostra, o vero a le Maestà delli Serenissimi suoi figliuoli. Esso è inclinato a far viaggi e massime in Turchia, dove à qualche principio della lingua, et nel praticarvi per lo avenire la potria finire de imparare. E giovine animoso, andara in capo del mondo se la Maestà Vostra cello comandara; è di eta di venticinque anni e di madre tedescha, nato a Nurimbergo. Parla italiano e latino; è giovine da durar fattica, et si affaticara voluntieri, ma che li sia comandato'.

14 Stopio to Fugger, 16 January 1568: '[Strada] < .. >andava qui per la terra $<\ldots$.. con le calze di scarlato, col figliuolo per paggio et 3. o 4 di questi suoi sanzali appresso che pareva un conte et cavalliere, ma prometto a V.S. che questa terra non vuol tal procedere $<. . .>$ ' (BHStS, Kurbayern, Äusseres Archiv 4852, fol. 122).

15 Ibidem, 31 August 1567 , fol. 56: 'Et così si pratica di longo, come penso haveria scritto a Sua Eccellenza, per la lettera che hora mando, la sop[ra]scrittion è di man sua, secondo la sua grammatica 'obsserv.mo', con 'b' et 'ss', non so se per di dentro havera anche detto secondo la sua rara dottrina 'efitt.mo', ò che l'havera fatto scrivere Thodesco dal figliuolo'. Various documents and letters preserved among Strada's files are in Ottavio or Paolo's hands. 


\subsection{Ottavio Strada's Role}

Stopio's letters to Fugger afford other occasional vignettes of Ottavio's role: for instance when in the late summer of 1567 Strada had to flee Mantua in fear of the Inquisition, Ottavio was to remain in the lodgings they had rented to oversee the execution of Strada's commissions, among which the manufacture of an ebony chest. At seventeen Ottavio in his innocence was no match for the dishonest joiner who made it, who sent him out of the house on some errand, and then broke open Strada's treasure chest and decamped with the considerable sum of three hundred scudi. ${ }^{16}$ In later life Ottavio would be regularly employed as an agent in his father's business affairs, concluding deals, collecting payments, and supervising commissions. Thus in March 1574 Strada told Hans Jakob Fugger that he intended to send Ottavio to Venice 'for some business affairs of mine', offering to have him act on Fugger's behalf in the acquisition of some collections of antiquities, and from a letter to Jacopo Dani of the same year it transpires that Ottavio had recently travelled to the Southern Netherlands, from which he had brought numismatic materials-doubtless among other things. ${ }^{17}$ When a year earlier Ottavio had visited Augsburg, he had shown Hans Fugger, Hans Jakob's cousin, several books of drawings. One of these particularly interested Fugger, a volume containing only 'Citata oder

16 BHStA, Kurbayern, Äusseres Archiv 4852, fol. 69, Stopio to Fugger, Venice 5 October 1567: 'Il Strada era per comprare qui assai medaglie da uno che me le ha gia offerte, ma li furono robbati da 300 [scu]di in Mantua, da uno che li faceva una cassetta d'Ebano in casa, essendo esso Strada partito per Verona, per paura della Inquisitione $<\ldots>$ per il che se ne ando subito via, per Verona, lasciando il suo puto in Mantua, con collui che fece la cassetta, il quale mando poi fuori il figlio in un servizio, et in quel mezzo ruppe la serratura ad una cassetta ove erano li danari, et scampo via, et il puto ando poi con quello haveva trovato avanzare in casa a trovare il padre a Verona, et non fidandosi ne anche ivi venne poi di longo a Ven[eti]a, over per rispetto de l'Imp[erato]re non li haveriano lasciato dare molestia<...>'.

17 Strada to Hans Jakob Fugger (Doc. 1574-03-01): 'a Dio piacendo voglio mandar Ottavio mio figliolo a Vinetia per alcuni mei negotij, e se pole servire la Signoria Vostra in qualche cosa lo farà voluntieri. Anche se Sua Excellenza vole che faccia praticha con li Vendramini di quel suo studio delle antiquità, o vero con quello del Cavaliero Mozenigo, qual sia il più bello che ora in Vinetia si trovi, del quale intendo se ne vole desfare, io farò che ne cavarà li inventarij, e si mandaranno a Sua Excellenza, si che Vostra Signoria me potrà avisar del tutto quello vorà che si faccia.'; Strada to Jacopo Dani (Doc. 1574-07-11): 'Del favore che Vostra Signoria mi dice che Sua Altezza mi farra per la mia Series, ritrovandosene ne molte doppie, la ringratio con tutto il cuore, et gliene basio le mani; ma creddo che poche or mai me ne manchi, et poche se ne truovi che io non l'habbi; perchè in tanti anni ch'io vi sonno a torno, et in tante parti dove son stato, et doppo Ottavio mio figliuolo che ultimamente è stato in Fiandra, creddo che habbiamo ragunato tutto quello che si truova'. 
hirnhauben'-ornamented helmets-which was doubtless similar or identical to the album Galearum antiquarum discussed above [Ch. 4.3.5, Figs. 4.26-4.31]. The commercial nature of such contacts is clear: Fugger subsequently wrote to an agent in Vienna to enquire, but cautioned him to dissimulate his interest, fearing that 'should he know that I would like to have it, he would make me pay dearly for it'. 18

By that time the affairs in which Jacopo employed Ottavio were mostly related to his publishing project, as is evident from a long report Ottavio wrote in the late autumn of 1574, in response to a lost letter from his father, detailing his activities in Frankfurt and Nuremberg. This interesting document provides some information about Ottavio's character, showing him in a not very favourable light, for instance in his description of the treatment he meted out to a drunken servant and in his comment on the engraver Martino Rota's waywardness. ${ }^{19}$ But it also provides some more general idea of the Stradas' business interests, and of Ottavio's role in his father's concerns.
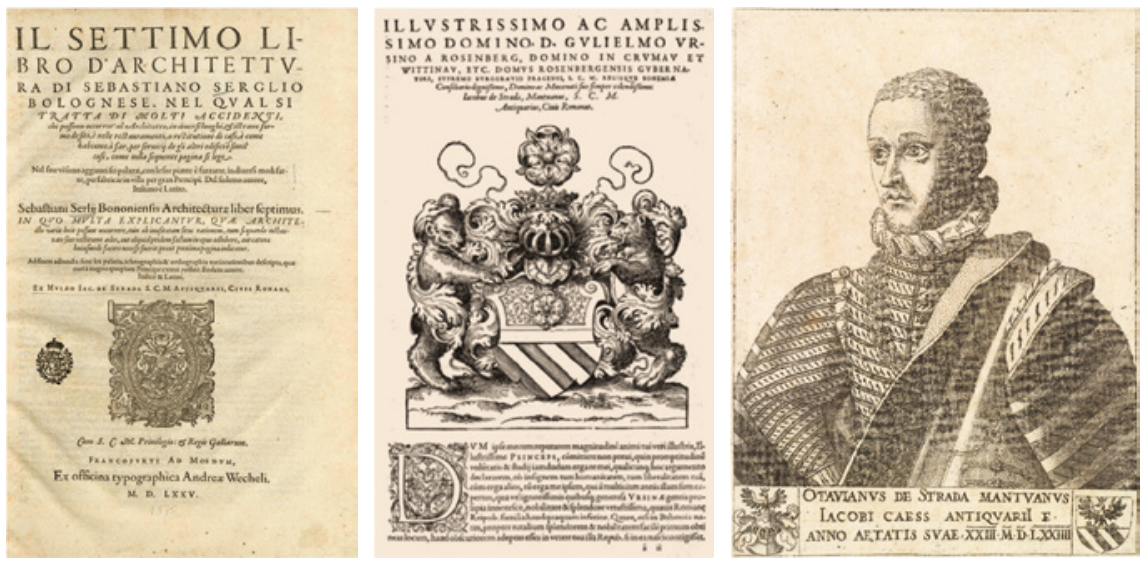

FIGURES 14.3-14.4 Titlepage and dedication to Vilém z Rožmberka of Strada's edition of Sebastiano Serlio, Settimo libro d'Architettura, Frankfurt 1575.

FIGURE 14.5

Martino Rota, portrait of Ottavio Strada at the time he was overseeing the printing of the Settimo Libro, engraving, 1574; Windsor, Royal Library.

18 Hans Fugger to Hans Gärtner in Vienna, 29 April 1573: 'Unnder ander gemalten büechern, so obgemelter Octavian Strada mir gezaigt, ist ainer, darin lautter Citata oder hirnhauben gemacht. Da ichs khündt umb ain billiges bekhummen, wollt ich mich mit im einlassen, ir müget mit geschicklichkhait solliches bei im anbringen. Er ist gar ein heelkonz, und da er merckhen solte, das ich das buech gern hett, wuerd er mirs theuer salzen'; quoted in Lehmann 1956-196o, I, pp. 264-265.

19 'Del mio servidor, lo caciarò al bordello, perchè non val nulla; io li ò basimato pareche volte, ma non iova niente. Io ne scrissi in Augusta per un ragazo fidato; costui non lasserebe se l'Imperatore lo vietasse di imbriecarsi, et quando lo imbriaco, vole bravar; in Francoforte ero sforzato di rumperli la testa in 3 lochi. Quando mi partirò de qui lo cac- 
Ottavio's principal task was overseeing the printing of Sebastiano Serlio's Settimo libro d'Architettura. This implied preparing the definitive manuscript of the text for the typesetters, and included dealing with an anonymous 'Dotor Mantuano'-according to Ottavio the only learned Italian present in Frankfurt - who was to correct the Italian text, and with the printer-publisher, Andreas Wechel, who had agreed to print the book. It also implied the acquisition of the paper, which involved him in negotiations with the other notable Frankfurt printer, Sigmund Feyerabend, who reassured him about the quality of the paper he had acquired. Feyerabend also was instrumental in finding a translator for a planned German edition of the book. For the Settimo Libro Ottavio did not need to commission the illustrations, which the elder Strada had had engraved in Venice, though a part of the woodblocks unfortunately had been damaged in the transport to Frankfurt. ${ }^{20}$ Ottavio did, however, commission a new woodcut with the coat of arms of Vilém z Rožmberk, to whom his father had decided to dedicate the edition. Moreover he was engaged in the preparation of several other projects, likewise trying to find a translator for the texts and commissioning the designs and overseeing the execution of the woodcuts or engravings for these. He also bought a quantity of books from Feyerabend, a few of which he thought to retain for the Musaeum, but most of which he intended to use to pay the engravers in kind, or which he suggests his father could use to barter against other books. At the same time he was expected to maintain the network his father had built up

ciarò via' and 'Del Martino non è pacato, se ben è povero homo e superbo; Voi vedrete che Dio lo castigar Et se lui non vi vole render quelli danari che li prestai bisogno far conto che li abbia per 'I mio ritratto. Quando havera fame 'l vera a lavorare, et fate lavorare in la Series se'l vora lavorar; più presto ci daria di più quache [sic] coseta per rame, acciò che andasi inanti'. His profiting from Sigmund Feyeraend's discomfiture by acquiring at half its value a fur-lined chamber cloak, which the printer was not allowed to wear because of the Frankfurt sumptuary laws, shows that he knew how to drive a hard bargain: 'Io comprai una veste di notte di lui per $20 \mathrm{Fl}$.; sapiate che li è costato a lui più che 40, quella di tomascho fodrata davanti con mar[tora?] largo un palmo, et l`è bella nova; lui non la pole portare perchè li signori li anno vietato, et lui non à portato 3 volte. S'avesse fatto far una solum di Mochardo [? a type of fabric?] me havera costato quel danaro, et li pago in due Fiera, hogni Fiera $10 \mathrm{Fl}$., et se non havesse trovato questa ventura, saria stato sforzato di farmene una. Perchè la notte mi levo et lavoro, et la stufa è freda, mi bisogno provedere d'una, se non havessi havuta questa<...>' (Doc. 1574-12-05, Appendix A); the letter is discussed in detail in Jansen 2004, pp. 192-193).

20 In the published book the defects in the illustrations Strada signalled ('per conto che sonno mal stampate, et che non venghino ben negri' are not really noticeable; though the black fields filling the window frames are not always black through and through, I find it difficult to imagine how this could have been the result of the damage caused by faulty packing mentioned by Ottavio. Perhaps Strada had the damaged ones recut? 
over the years, visiting or corresponding with business relations, patrons and potential collaborators. ${ }^{21}$

For many of these activities Ottavio needed ready money to pay his various contributors, and his letter includes much information about his expenses and a repeated request to send further funds as soon as possible: 'Try hard, father, to send me as much money as you can, for when I can do little here, my staying is not worth the expense.. ${ }^{22}$ Ottavio was sufficiently in his father's confidence to counsel him about the feasibility of various projects, and to be entrusted with these negotiations and with large amounts of money. Nevertheless Jacopo followed Ottavio's activities quite closely and critically: thus he appears to have objected to his departure from Frankfurt to Nuremberg, which Ottavio justified by an outbreak of the plague. Referring to testimony of his father's business associate Paolino Nieri, Paolo stressed that it claimed over two hundred victims a week, and that Feyerabend himself had decided to flee to Nuremberg in Ottavio's company. Yet Ottavio's letter, business-like but at the same time chatty and intimate, as yet gives no inkling of the clamorous breach in the relations between father and son which took place a few years later, which led to Strada largely disinheriting his once favourite son, citing no less than sixteen alleged 'crimes'. At least some of these related to a less than honest stewardship in the printing business, an allegation to which I will return later in this chapter.

\subsection{The Publishing Project: Strada Ambitions as a Publisher}

\subsubsection{The Epitome Thesauri Antiquitatum}

Ottavio's letter is a fascinating introduction to Strada's ambitions as a publisher. These were probably at least in part the result of his intimacy with the great book-lover and collector Hans Jakob Fugger and the many scholars in his

21 Ottavio mentions contacts with Paolino and Francesco Nieri or Neri, merchants from Lucca, his father's business partners, and with the Werdeman, bankers in Nuremberg; Mino Celsi and Giovanni Bernardino Bonifacio, marquis of Oria, the two famous evangelical exiles from Italy who were involved in establishing the texts of the Serlio volumes; and the humanist Giovanni Battista Fonteo, employed to provide texts for another project; he promises to visit Vilém z Rožmberk in his father's name. The level of Ottavio's contacts at the Imperial court are indicated by his request that his father greet 'Messer Martin', doubtless Strada's old acquaintance, Maximilian's chamberlain Martín de Guzmán, and Alfonso II del Carretto, marquis of Finale, at the time at court to plead the restitution of his territories.

22 DOC 1574-12-05: 'Circate, Signor Padre, di mandarmi più denari che potiate $<\ldots$,. perchè facendo poco qui non merita la spesa'. 


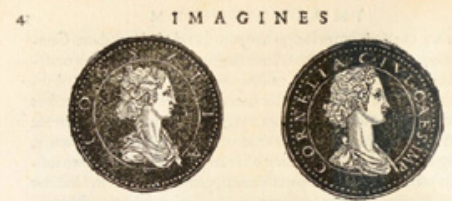

coss $v$ i $t$ A diucs admodum, fed e familia equef ri, puero pene adhuc $\mathrm{C} x$ fari defponfara fuit , quam L patre amiffoper renuntiationem in fponfalibus dimific.

cos N E L. IA Cinne quater confolis filia fuit, ex qua Iuliam fiLum genuit. Hanc Corneliam vxoré Cxfar mirìm amxuit, veţ́, eam repudiarce, nulla re a Sylla Dietatore perfiaderi potuit, aut compelli, imo $\&$ definctam pro roftris laudauic oratione cultifsima : magnam hine popularem bencwolentiam affecutus, Eius etizm fratrem L. Cinnam, qui in ciull difcordia Lepidum featus, cxulaucrat,peduxit.
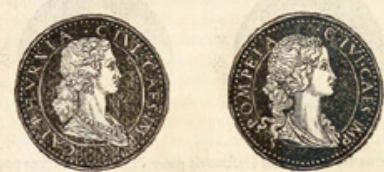

ro m r x rA Q. Pompei filia LSylle neptis,quam Cxfar in lo-

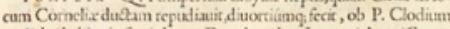
mulicbrihsbitu in facris bon. . Dex dep̧echenfum, ģui deperifle eam ferbatur, atcue adulterifle.

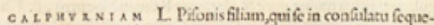
batre, $C$ ffir in vxorem duxit, Vitrimum hocipfius fut matrino. num, in eo crim oceifis eft. Hac multum C.erarem amauic, pluri. múmque co dic,quo in Scustu occifus cft, fomnio territa ( Nam ma-

$1 \mathrm{MAGINE}$

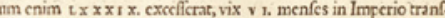
cgit. Brumix oppido Moratix mortuts, 8 in Monafterio S.Tho mx, cum patre fwo,qui id conftruxerat, fcpultus.

IO Do cv s Imperator vxorem habuit Reginam Hungarix ex cua nullam prolem genuit.

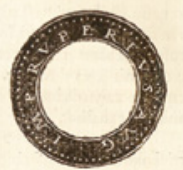

R V P E R T V S Dux Bumarix \& Comes Palatinus Rheni, flius Rupcru Adolphi \& Bcatricis, vir armis cxercitatifsimus, ingeniq; acerrimi, ac infignis iuftitix cultor. Poft Fridcricum Duecm Brunfuicenfem Cxfarem cuidem elcctum, fed a Moguntino Anti. ftute impic occifum, ac propter illius mortem diu multimese in Germanis tumulruatum, lmperator à Princivibus decharatus eft, Bonifa. co $1 x$. ą̧robante, \& Colonix ab Archicpifcopo Colonicnfi Rcgio diadcmate infignitus. A Florentinis ad comprimendam Galea. cionzm potentiam, in Italiam defcendit : Prxídio autem Ducis Auftriaci,s Epifcopı Colonicnfis deftitutus, congreffus cí Vicecomitc fuccubuit, fugague faluti confuluit. Vnde ad Tridentinos \& Venetos delarus,cuim honorificcntifsimè acceptus eft. Ac cimm Pontefici, Venetis \& Horentinis crarrata clade fua, furdis fabulam cancret, re infeota in Germuniam per Alpes cum equitatu rcuerfus, res Imperii cum diligentia traalauit, de Italia nilil ampliès folcitus, quam permifit fuis fe vulncribus conficere. Poft pleraque autem in Impcrio honorficè gefta,infererà in Oppenhein diem fium obiit, ac $\mathrm{Hey}$ dellberg $x$ f́pultus anno Imperia $\mathrm{x}$.

Vxorem habuit Rupertus, cuius nomen, genus \& familia inco. gnitacft, ex qua genut Rupcrtum cognomine Pịam Palatinum,
I M PERATOR V M.

ritum in gremio fuo confodi fomniabat) hortari cappit, nc Curiam ingredcretur. Poft Cxfanis uxrò cxcifonemad xdec M Antonife conculy, Pothes conalit,

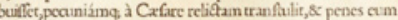
depofint.
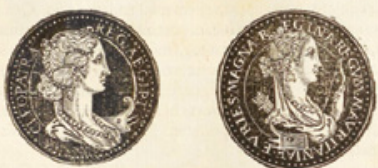

CL r op A r a s Acgypti Regina, a Pothino rogno cieta, Cxfarem ad fe amandum allexit : qui fplendore formx, \& g gudam fermonis gratia viftus, pamnon niti maximis honoribus, peramiliç, auxit, ac ita fratri neconcliauit, vt pariter regai gubernacula teneret. Mox M.Antonuan guoguc Impcrium Acgypti occupantem, ob/ccuio corporis dcuinxit, In beilo cum Augufto \& Antonio, cùm cfrent fiverari, Alexandriam confugerunz: whi fe Antonius interfe-

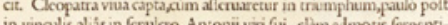
in vinculs, al..sin ki fulco An bus vberibus fuis,concidit, Anno xtatis fixx trigefmonono.

Ev ru Es Marz, Bogudis Regis Mauritanix vxor, a Cafare ad-

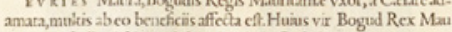
ritanix, in bello Africo crixè iunit partes $\mathrm{Cxfaris}$.
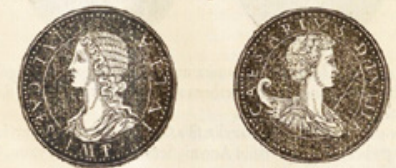

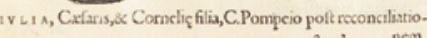
a 3 nem,

I M PER A T OR V M.

329

qui cum loanne Duce Burgundix à Turca captus, poft liberationem fine vxore \& liberis Ambergx moritur, atque ibilicpelitur.

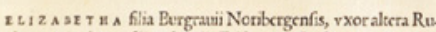
perti,cx çua quinque filios fuftulit, Fridcrioum, Ledouicum, Steplu. num,lounnem, \&x Othenem, ac tres flins.

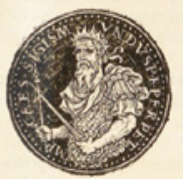

S I G I S M V N D V S Caroli n11. Imperatoris ex Ioanna filius, princeps fapicntia,cruditionc, probitatc, \& meltarum linguaum cognitione darifsimus, flatura talis, qualistantum prind. pemdecebac. Hic adlux puer Mariam filí, Ludouici Regis Hungarix yxorem duxit, ac Rex Hungrix deinde Romanonum faftus ucrfis Tercas maximum parauit cxercitum, címque ad Adrianopolim vfque perduxit. Verum perturbatis ordin bus à Gallis, prinum locum in acie debcri fbi contendentibus, ab Amurathe graui prxlio vietus, caff rifque cxutus eft, cafis magna ex parte ducibus, sx Burgundionum Rege casto. Triennjo magnam Europ $x$ partem publi.

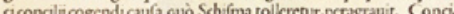
jonclo annem $x \times 11$. Gregorium \& Bencdithm Pontificia dignitate annem $x \times 11$. Gregortum \& Benctichim Pontifita dignitatc
dqpofwit, \& in Pentifictu Othonem de Colimna, Mattunum cuin. tum poftea dictum, fiffecit, ac ferniciofo fduifmate inter Pontifices fublato,concordiam \& trancenlitatem Ecciff $x$ reftisuir.In co eciam concilio Friderico Burgravio Nor bergenfi ob excellentes eius virtutes, ius electiuum Impcrii donauit. Deinde in Italiam r roficetus, Mediolanum venit,acceptáque de merc Impratorio, ferrea cerona, Parmam, Scnas, Rominquc profectus à Pontifice, Cardinalibus, po

FIGURES 14.6-14.9 Strada's Epitome thesauri antiquitatum, Lyon 1553: pages 4-5 (coins and vitae of women related to Julius Caesar) and 328-329: coins and vitae of Rupert, Elector Palatine and King of the Romans, and Emperor Sigismund iv. Note that when no 'authentic' image was available, an empty ring afforded space for a later manuscript addition. 
circle, including one of the first systematic bibliographers, the famous natural historian Conrad Gesner. Practical experience of the printing house Strada obtained at the latest in 1553, when he supervised the printing of the Latin and French editions of his numismatic treatise in Lyon, but it seems likely that through his sojourn in Germany he had a long-standing acquaintance with the trade as practiced in Nuremberg, where he had settled in the early 1540 , and in Frankfurt and Augsburg.

That Strada intended to set up as a publisher himself, rather than just as an author, is already evident on the title page of his Lyon Epitome thesauri antiquitatum: though the colophon gives the name of the printer, Jean de Tournes, the title page gives as publisher's address 'Lugduni: Apud Jacobum de Strada et Thomam Guerinum', and shows a printer's mark which is Strada's own [cf. above, Fig. 3.18]. The book, the printing of which was finished on the sixth of November 1553, was provided with a copyright privilege conceded by the French King Henry II to 'nos bien aymez Iacques de Strada Mantouan et Thomas Guerin Marchand Libraire demourant à Lyon'.

That Guerin is mentioned as a marchand-libraire suggests that he was the partner who contributed the practical know-how and contacts; yet in view of the use of Strada's device on the title page there can be little doubt that he must be considered the senior partner, who not only contributed the content of the book, but also provided the major investment for its production. That he could do so doubtless was due to financial support accorded by Hans Jakob Fugger, to whom both editions of the book were dedicated [cf. above, Fig. 3.19]. In the following a chronological review will be given of Strada's largely unsuccessful attempts to set up as a publisher on a grand scale.

That this was a serious ambition and that Strada had prepared it well is already clear from his first production. The Epitome thesauri antiquitatum was a beautiful book, printed with large margins on high-quality paper and illustrated by a huge number of specially prepared woodcut illustrations of which Strada, according to his preface, was quite proud [Figs. 14.6-14.9]. Even more significantly, the book was simultaneously printed in a Latin and a French edition: Strada must have gone to some lengths to find and to remunerate a sufficiently learned translator. He spotted the talent of the Orléans humanist Jean Louveau, who after having translated the Epitome du Thrésor, would build up a modest reputation as a translator of various Greek (Eustathius), Latin (Apuleius, Erasmus) and Italian texts published by Lyon printers such as De Tournes, Granjon and Rouillé. ${ }^{23}$ The book was a success, doubtless

23 Rigoley de Juvigny, Les Bibliothèques françoises de La Croix du Maine et de Du Verdier, sieur de Vauprivas, Nouvelle édition, IV, Paris 1773, p. 453. 
534

Oo baber von beasen erfetiffiget / oic bano vnno den ftums pen bef

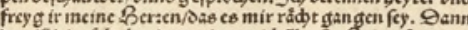

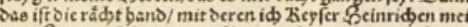

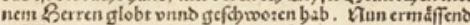

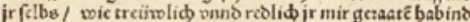
Sas id von im abfallen fotre. Oarumb id ice meinesmein cyos biinh

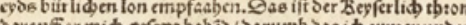
otrauff cr midg gefice weyfing vano leer gefolget bab. 2̇s måace beffer groefen i申

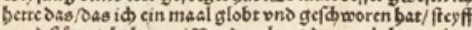

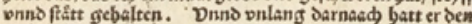
gett: auffgeben,

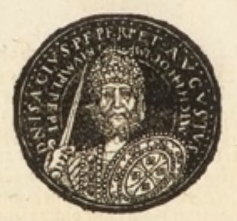

Sefor

Sacills Comuenus/ ift surd bilff se $\beta$ patriardyen in Conftantinopel zum Zey fertbumb fommen / $\mathbf{v}$ at sú regieren angbept/als man alt von Der mít anfang fer 7 ef

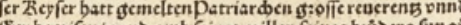
Eer bcwifen/vnno pumb fsinet willen feincs batúbers fun zŭ boden fürtreffecenliden wiroinen vnnঠ ecren ámpteren ers bept. Jber dife freënorfdalfit batt nir lang gewćret. Oann

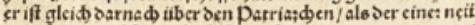

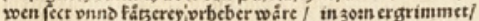

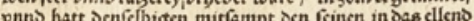

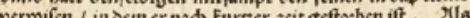

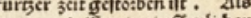

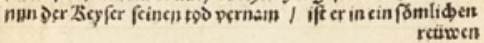

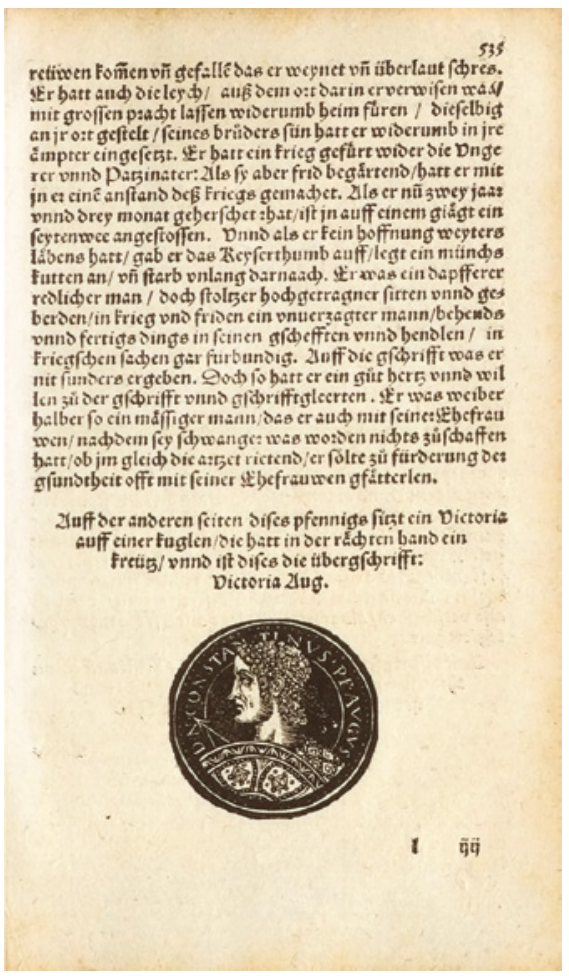

FIGURES 14.10-14.11 Copies after Jacopo Strada, images of Isaac I Komnenus and

Constantine X Doukas in Diethelm Keller, Kunstliche und aigendtliche Bildtnussen der rhomischen Keyseren, ihrer Weybern und Kindern, Zürich 1558 , which is a reworking of Strada's 1553 Epitome thesauri antiquitatum, for which new woodcuts were made, copied from Strada's illustrations.

partly thanks to the large quantity of woodcut illustrations, attributed to Bernard Salomon, that Strada had commissioned for it. It filled a niche in the demand for easily digestible information about the history of Imperial Rome, and about its coins: because of their relative accessibility, their (often) relatively low cost, and their small bulk, these had become the most widely coveted collector's items both among scholars and aristocratic and bourgeois amateurs. ${ }^{24}$

24 The Epitome thesauri antiquitatum is one of the earliest of a host of similar illustrated numismatic treatises published in the mid-sixteenth century: cf. Cartier 1937, pp. 357-359; Rave 1959; Jansen 1991, pp. 59 and 66; Haskell 1993, 'The Early Numismatists', pp. 11-25; 

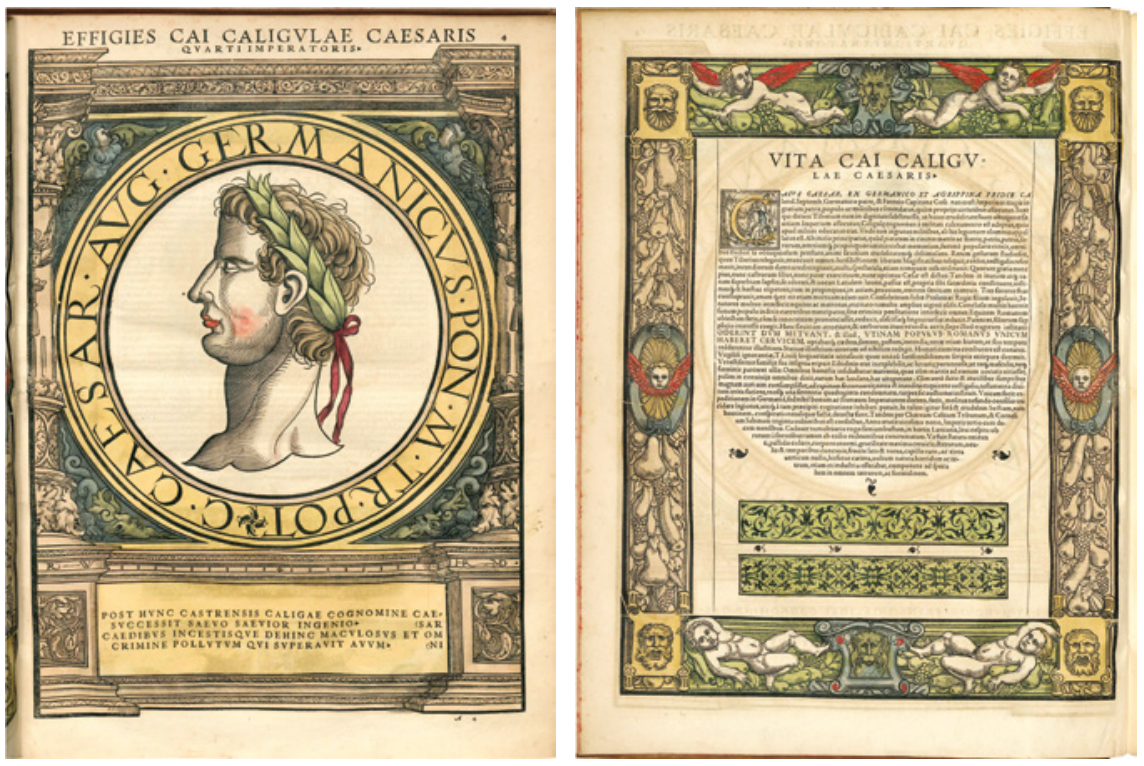

FIGURES $14.12-14.13$

Portrait of The Emperor Caligula, from Jacopo Strada, Imperatorum Romanorum omnium orientalium et occidentalium verissimae imagines, Zürich 1559; this reuses a selection of Strada's texts to accompany a reissue of a set of earlier woodcuts woodcuts by Rudolf Wyssenbach (the portraits), Hans Rudolf Manuel Deutsch the Younger (ornamental frames) and Peter Flötner (ornamental vignettes).

It was even such a success that the volume was reprinted repeatedly within the next five years, both in a Latin and a German edition illustrated by exact copies of Strada's woodcut illustrations - the expense this involved indicates that its publisher, Andreas Gessner at Zürich, expected quite substantial sales [Figs. 14.10-14.11]. Gessner also published a splendid folio edition in which Strada's biographies were used as textual complement to a series of rather splendid Imperial portrait heads, earlier woodcuts by Rudolf Wyssenbach dating back to 1547 , which were set in full-page decorative frames newly-cut by Hans Rudolf Manuel Deutsch the Younger [Fig. 14.12-14.13]. That these editions do not reuse Strada's original woodblocks indicate that they were pirated editions, in which Strada himself had not been involved: a supposition strengthened by

Jansen 1993, pp. 212-213; Dekesel 1997, pp. 871-875; Cunnally 1999, pp. 26-33, 208-209; Pelc 2002, cat. nrs. 96 (pp. 207-208) and 142, 143, 144 (pp. 253-255); Heenes 2003, pp. 18-20. 
Ottavio's advice in his 1574 letter to his father not to publish a German edition of the Epitome, because a German edition already existed, 'with the same medals as ours.'. 25

\subsubsection{The Copyright Privilege of January 1556}

The many copies preserved are another indication that the Epitome thesauri antiquitatum was a success. Certainly it also will have increased Strada's prestige, so it is not surprising that he intended to continue the experiment. So once returned to Nuremberg in late 1555 , he prepared a request to the Emperor Charles $\mathrm{v}$ for a copyright privilege pertaining to a number of books he was preparing and intended to publish at short notice. The privilege was granted on 8 January 1556. It describes five quite substantial encyclopaedic historical works. The first of these is a complete edition of the Fasti consulari et triumphali, a huge inscription listing the names of the annually elected magistrates of the Roman Republic. ${ }^{26}$ As mentioned in Chapter 3.6, the fragments of this had been found in the Forum Romanum in 1546, and on the initiative of Cardinal Alessandro Farnese had been collected and set up in a room in Michelangelo's Palazzo dei Conservatori on the Capitol. Known since then as the Fasti capitolini, this serial inscription was of great value in establishing the chronology of the Roman Republic and the Empire, and had already given rise to several publications and controversies. It had been transcribed and edited by Onofrio

25 Doc. 1574-12-05: 'Della Epitome l'è ben vero che sarebe un bella cosa se fusse stampato in totesco, ma l de già vi è stampato in todesco, con le medeme medaglie come le nostre; però se volesse far quella spesa bisognerei far le roversi apresso, et costarebe troppo'. Strada 1557 was an exact copy of Strada's own edition, printed by Andreas Gessner in Zürich. Diethelm Keller's Kunstliche und aigendtliche Bildtnussen der rhomischen Keyseren, ihrer Weybern und Kindern, Zürich 1558, is a reworking of Strada's Epitome thesauri antiquitatum and Guillaume Rouille's Promptuaire des médailles, using woodcuts carefully copied from Strada's book; Imperatorum Romanorum omnium orientalium et occidentalium verissimae imagines, Zürich 1559, uses a selection of Strada's biographies to explain Rudolf Wyssenbach's earlier series of woodcuts. Both books were again published by Andreas Gessner in Zürich. Surveys of all editions in Dekesel 1997, pp. 871-875, cat. nr 5/ S70-S74 (Cat. 5), and Pelc 2002, cat. nrs. 96 (pp. 207-208) and 142, 143, 144 (pp. 253-255).

26 Doc 1556-01-08: 'Fasti in Romana historia ab urbe condita, hoc est regum, consulum, dictatorum, magistrorum equitum, tribunorum militum consularis potestatis, censorum, imperatorum et aliorum quorundam magistratuum Romanorum, una cum ovationibus eorum et triumphis, a Romulo rege primo usque ad imperatorum Carolum Quintum augustum, tum ex Capitolio tum reliquis antiquissimis monumentis desumptos Onophrio Panvinio, Veronensi, auctore, tomus primus, ex museo Jacobi de Strada, Mantuani antiquarii'. 
Panvinio, a prodigiously learned young Dominican working in the orbit of Cardinal Farnese and a good friend and protégé of Antonio Agustín. Doubtless it was through Agustín that Panvinio and Strada met; in any case he was involved in drawing up the contract which gave Strada the right to publish Panvinio's efforts. ${ }^{27}$

Since the copyright privilege indicates Panvinio's Fasti as 'Tomus Primus', Strada appears to have conceived it as a companion volume of his own numismatic compendium of the Roman Empire, which follows it in the copyright privilege and is indicated as Tomus Secundus. This was a 'universal description' of all the coins issued by the Roman Emperors and their successors from Julius Caesar up to the ruling Emperor, Charles v. ${ }^{28}$ It is in fact the numismatic corpus announced in the preface to the Epitome thesauri antiquitatum, which, as its title indicates, is a resumé of this more ambitious work. It was based on the collections of sketches, casts, descriptions of Roman coins Strada had brought together: the same material on which he drew for the Magnum ac novum opus, the corpus of numismatic drawings commissioned by Hans Jakob Fugger, and the accompanying volumes of detailed descriptions of obverses and reverses of each individual coin-type. ${ }^{29}$ In the following years it would grow in ambition and size, but it would never be printed, though it doubtless provided the basis for Ottavio Strada's De vitis imperatorum et caesarum Romanorum, posthumously published in three volumes in Frankfurt in 1615-1618 [below, Figs. 14.47-14.48].30 That Strada conceived Panvinio's Fasti et triumphi and his own numismatic corpus as complementary volumes is not illogical: the huge epigraphic state calendar, listing all the magistrates of the Roman Republic and the Empire, and the coins issued by the Emperors, together provide the principal authentic, contemporary sources on the chronology and the political history of the Roman Empire.

The ecclesiastical history of the Empire was to be served by the publication of another work that Strada had obtained from Onofrio Panvinio, a 'brief description' of the Popes from St Peter up to the ruling pontiff, Paul IV Carafa, giving a summary survey of the election, the principal acts and death of each Pope, and a list of the cardinals they created. It is a work of reference

27 Doc. 1557-11-27; cf. above, chs. 3.6.2 and 4.2.

28 Doc 1556-01-08: 'Universalis descriptio numismatum omnium imperatorum ex aere, argento et auro a Julio Caesare usque ad Carolum Quintum imperatorem augustum, que quidem hodie in Italia, Gallia, Germania variisque hinc inde locis inveniri potuerunt, Jacobo de Strada, Mantuano antiquario, aucthore, tomus secundus'.

29 Described above, Ch. 3.3.

3o Cf. below, Ch. 14.5.4. 

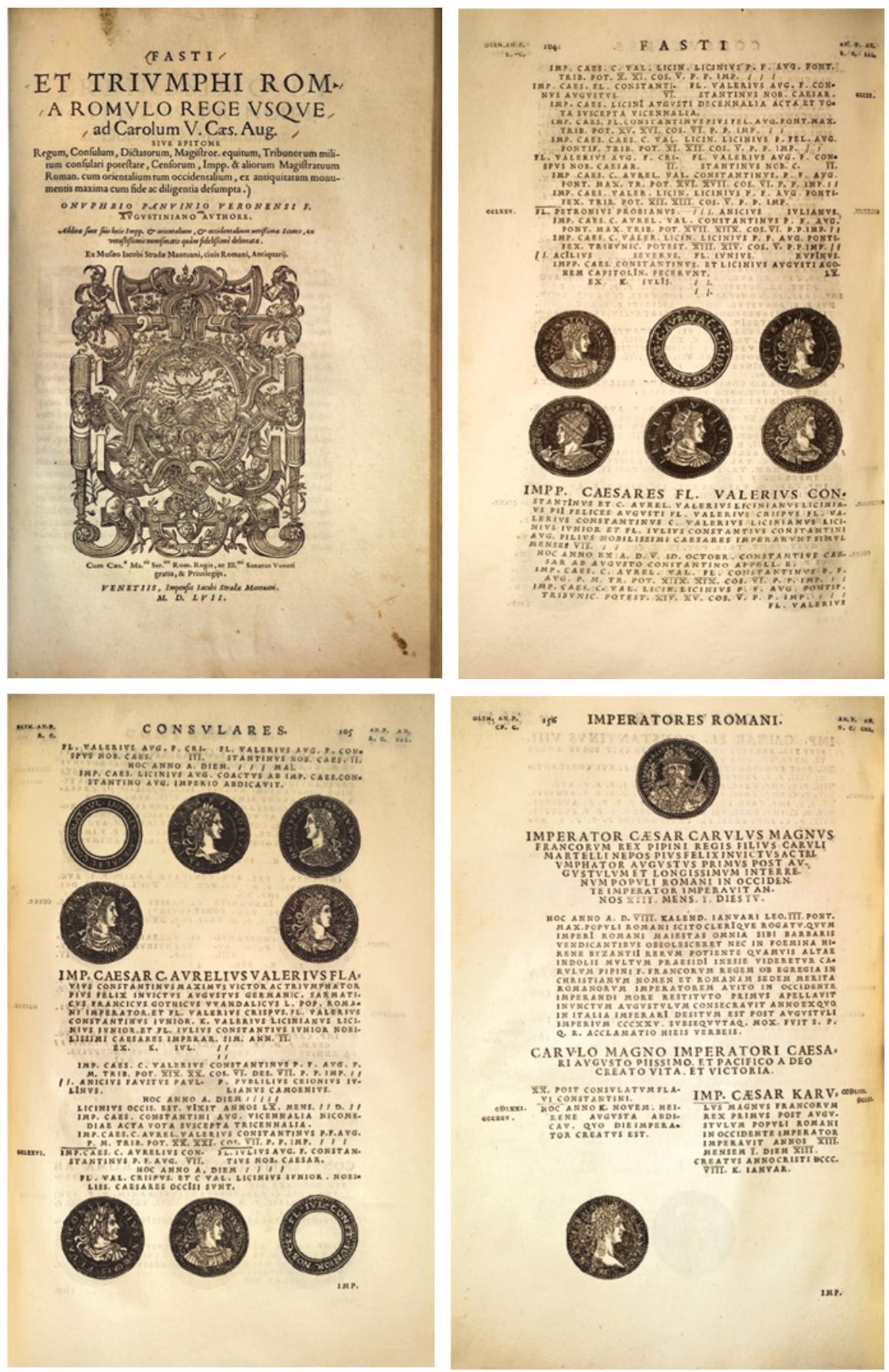

FIGURES 14.14-14.17

Title page and pages 104-105 of Strada's edition of Onofrio Panvinio's Fasti et triumphi Rom. a Romulo Rege usque ad Carolum v. Caes. Aug., Venice 1557: coins of the successors of Constantine II and of Charlemagne. 
that mirrors and complements Strada's Epitome thesauri antiquitatum, which presented similar abridged lives of the Emperors. ${ }^{31}$ So it is doubtless no coincidence that Strada published Panvinio's book under the title Epitome pontificum romanorum.

The copyright privilege mentions two other works which were never published, but which in future would loom ever larger in Strada's publishing projects. In fact it was Strada's increasing ambition for these projects and the megalomaniac size they assumed over the course of the years that prevented their realization. The first is a 'universal' dictionary in the three classical languages, Greek, Latin and Hebrew, explaining all words and concepts, both ancient and contemporary, in these three languages. ${ }^{32}$ This was something which had been attempted before. What was exceptional was Strada's intention to illustrate the entries not only with text passages, but also with 'figures' (here: tables and schemes) and 'images' drawn from his collection of ancient and modern sources. The use of appropriate images to illustrate the argument was also intended in the last book mentioned in the privilege, a corrected Latin translation of Leandro Alberti's $155^{\circ}$ Descrittione di tutta Italia. ${ }^{33}$

\subsubsection{The Two Books Actually Published:The Fasti et Triumphi and Epitome Pontificum}

Of the five titles mentioned in the copyright privilege of January 1556 only two, the books compiled by Onofrio Panvinio, were ever published. These were printed in Venice at Strada's expense, as is explicitly stated on the title pages and confirmed by the bookplate, which is a variant of that used for the Lyon Epitome thesauri antiquitatum [Figs. 14.14 and 14.18]. Perhaps Strada may have been aware that the Lyon Epitome was being pirated by a Swiss printer at this very time, which may have been the reason why he took the trouble to obtain additional copyright privileges from Ferdinand I, King of the Romans, and from Lorenzo Priuli, Doge of Venice, included with that obtained from Charles

31 Doc. 1556-01-08: 'Brevis pontificum Romanorum descriptio a sancto Petro apostolo usque ad Paulum IIII. Caraffa Neapolitanum, cum singulorum conclavi et electione, item cardinalium creationes, tituli, legationes, patria, insignia et obitus, Onophrio Panvino, Veronense, Augustiniano authore, ex museo Jacobi de Strada, Mantuani antiquarii'.

32 Doc. 1556-01-08: 'Ingens thesaurus seu universale dictionarium rerum et verborum omniumque tam antiquitatum quam novitatum, non solum Latine, Grece et Hebraice explicatis, verum etiam figuris et imaginibus tam ex vetustis monumentis quam novis excerptis expressarum ex museo Jacobi de Strada, Mantuani antiquarii'.

33 Doc. 1556-01-08: 'Descriptio totius Italiae, antehac a F. Leandro Alberto, Bononiense, in Italo sermone scripta, nunc vero in Latinum sermonem conversa et a multis erroribus vindicata, preterea iconibus aliisque rebus scitu dignis expolita, ex museo ut supra $<\ldots>$ '. 
V in the book itself. ${ }^{34}$ The Venetian privilege, dated 27 April 1557 , is a terminus post quem for the actual printing of the book, the first sheets of which came off the press in October or November of that year. ${ }^{35}$

Strada paid much attention to the appearance of the books: both are set in beautiful type; the Fasti et triumphi is printed in two colours and was illustrated with imperial portraits, for which the woodblocks of the Lyon Epitome were reused [Figs. 14.15-14.17]; the Epitome pontificum was illustrated with woodcuts representing the coats of arms of each Pope and of the principal cardinals created during their reign [Figs. 14.19-14.20]. Unfortunately Strada paid less attention to the actual typesetting of the Fasti et triumphi, which resulted in an ill-corrected volume with typographical errors which made the book unreliable as a work of chronological reference. ${ }^{36}$ Understandably this infuriated Panvinio, who was in Venice at the time and decided to disavow
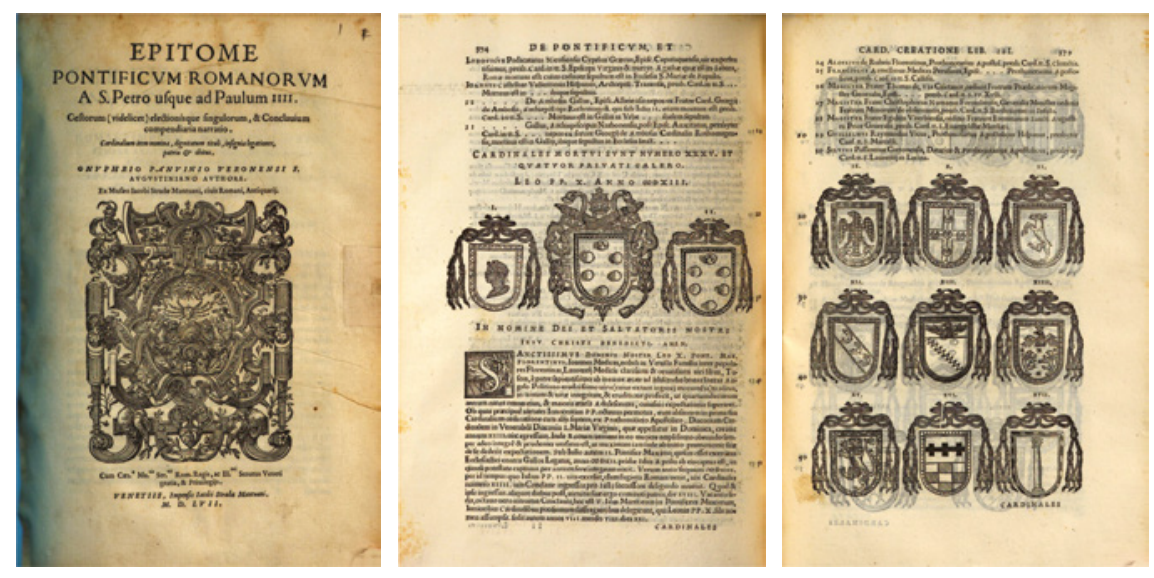

FIGURES 14.18-14.20 Strada's edition of Onofrio Panvinio's Epitome pontificum Romanorum, Venice 1557: title page; page 374: beginning of the entry of Leo X de' Medici, and p.379, part of the list and relevant illustrations of the fifth creation of cardinals during Leo's pontificate.

34 Docs. 1556-09-18 and 1557-04-27.

35 Doc. 1557-11-27.

36 Since Panvinio's chronological tables were based on the Fasti Capitolini, it would have been logical to number the Capitoline years on the left hand side, as they actually appear on the marbles, and the years according to the Varronian system on the right; yet in Strada's edition the headings to the columns on the first page indicate the opposite, and initially the years are in fact numbered as indicated in these headings. It appears, however, that this inconsistency was discovered after a few pages had been printed, and on page 5 the columns are tacitly shifted about: that is, from the year 250 ab urbe condita the Capitoline and Varronian calendars appear as they were presumably intended by Panvinio. But Strada, or his printer, neglected to correct the first five pages, which ought 
Strada's editions of his works: he almost immediately brought out his own, more correct editions of both: Romani pontifices et cardinales S.R.E. ab eisdam a Leone IX ad Paulum papam IV per quingentos annos posteriores a Christi natali annos creati (Venice, M. Tremezzino, 1557) and Fastorum libri V a Romulo rege usque ad Imp. Caes. Carolum V Austrium (Venice, V. Valgrisi, 1558).

As on his own Epitome thesauri antiquitatum, on the title page of his editions of Panvinio's works Strada proudly marks their provenance 'Ex Musaeo Jacobi Stradae, Mantuanae, Civis Romani, Antiquarij'. This probably implies that he had acquired the manuscript copies, but it is clear that his purchase had been made with the express intent to publish them. This is clear from Agustín's advising Panvinio that he was allowed to have his own versions printed if he wished, but that he ought to wait with actually selling copies of the titles he had sold to Strada until a decent time span had passed, say three to four years. ${ }^{37}$ So Panvinio had actually been paid for his work, which then as now was not always the case with authors of scholarly works. Moreover Strada had attempted to do Panvinio proud: the splendid execution of the Fasti et triumphi must have required a quite considerable investment. Panvinio understandably was more concerned with scholarly correctness than with splendid type and unnecessary imperial portraits, and certainly Strada's carelessness in not correcting the mistake in the Fasti cannot be condoned. Yet Panvinio's subsequent discrediting of Strada's editions - he actually accused Strada of having printed the Epitome pontificum without his consent-probably caused Strada the loss of almost the whole of his investment. Strada sold his volumes of both titles to Pietro Perna, the well-known Italian printer and bookseller from Basle, who was to market them, and would pay Strada in instalments, but even in 1564 Strada had not yet received anything at all. ${ }^{38}$ So it is not surprising

of course to have been reprinted entirely; even worse, he did not indicate what had happened, so that unsuspecting users would never notice the discrepancy. I am grateful to William McCuaig for having explained the nature of the mistake to me, published in his discussion of the Fasti editions (McCuaig 1991, pp. 153-154).

37 Doc. 1557-11-27, Agustín to Panvinio: 'Quanto alle cose del Strada mi rincresce assai che la sua stampa riesca così male come ditte; et essendo tanto differenza, potrete stampar il Vostro libro senza pericolo, presertim con tante altre cose che fanno non esser il medesimo libro; et fatte prima sopra questo diligenza con quelli che costì se ne intendono, perchè mi par cosa chiara poter Voi provar non esser quel libro suo questo Vostro. Quanto al patto farò io fede di quanto mi ricordo; di privilegi non potro farla, ma si bene che Vi fossi lecito stampar Voi i Vostri libri, ma non vender quello che vendesti a lui infra un certo tempo, mi par di tre o quatro anni. Poi che ogni sabbato mi potete scriver, et io rispondervi avisateme di quanto accade et occorre'.

38 In 1564 Strada asked Maximilian II for a letter of recommendation to the City Council of Frankfurt, to help him obtain his outstanding dues from Perna. One suspects that Perna's unwillingness to pay may have been partly or wholly due to a failure to actually sell the volumes (Doc 1564-00-0o). On Perna, see Perini 2002, who does not mention Strada. 
that in April 1558 Agustín reported to Panvinio: 'In Frankfurt I spoke to Strada, who appeared not to be very friendly disposed towards you. ${ }^{39}$

\subsection{The Musaeum as an Editorial Office?}

\subsubsection{The Copyright Privileges}

As we have seen in Chapter 4.2, Strada used the dedications of the Panvinio volumes as a ploy to gain access to the Imperial court, dedicating the Epitome pontificum to Emperor Ferdinand I, and the Fasti et triumphi to his son and heir presumptive, Maximilian, King of Bohemia. This strategy was successful, leading to Strada's appointment as architect and later also as antiquary to Ferdinand I and Maximilian II. One assumes that his new tasks left him less time to spend on his editorial ambitions. And it is true that the first concrete bit of evidence relating to a planned publication dates only from December of 1572, when Strada obtained a copyright privilege from King Charles IX of France for an edition of Julius Caesar's Commentaries.$^{40}$ Yet it would be a mistake to conclude that Strada had shelved his plans for the time being: there are several indications that even during the second half of the 1560 s, when he was strenuously occupied with his commissions from the Duke of Bavaria and-presumably-Maximilian II, while at the same time building his own house in Vienna, he regularly paid attention to his editorial projects. Certainly

39 Doc. 1558-04-11: 'In Francafort parlai col Strada, mostra non vi esser tropo amico .... Probably with some good will on both sides the problem might have been solved in a more elegant way, perhaps with a separately printed erratum; but Panvinio appears to have been as much a hothead as Strada himself, managing even to exasperate Agustín, the most sympathetic and friendly of men, and Panvinio' s most assiduous friend and patron: cf. Doc. 1558-07-09, Antonio Agustín to Onofrio Panvinio, Rome, 9 juli 1558: 'Non so qual furia vi faccia dir quel tanto male di quel amico, ne manco per qual demerito mio ditte di me due cose ladre et peggio!, che io habbia dato al Strada le arme di Cardinali, et che voglia scoprir a Mr. Paolo [= Manuzio] tutti i vostri secreti di iure Latii $<\ldots>$ La Cosa del Strada sta come sempre vi ho detto; che non vide, ne hebbe da me quelle arme, et che me importava, ne importa confessarlo?' There is no substance to Panvinio's suspicion that Strada was plagiarizing his collection of ecclesiastical coats of arms, since Strada had been collecting these himself for many years on behalf of Fugger, for whom he prepared no less than fifteen huge folio volumes with splendidly illuminated coats of arms of the Popes and of the princes, prelates and noble families of Italy; cf. above, Ch. 3.3. Though after the Fasti et triumphi debacle Strada was not 'very friendly' with Panvinio, he seems not to have discredited him with Fugger, who employed Panvinio in the 1560 as an informant in Rome and commissioned various manuscript works from him; cf. Hartig 1917(b); Maasen 1922, pp. 75, 76, 77; a selection of Fugger's letters to Panvinio published ibidem, pp. vi-viii and appendices 4 and 6-51, pp. 96-126.

Doc. 1572-12-25, printed in Strada's edition, Frankfurt 1575, discussed below. 
he remained involved in the book trade, as is clear from his trip to Frankfurt to collect his dues from Pietro Perna, and from the fact that in 1570 his was the address in Vienna where to buy copies of Castelvetro's translation of Aristotle's Poetics, published by the Vienna printer Kaspar Stainhofer, which suggest that Strada may have been instrumental in organizing and perhaps also financing the edition. ${ }^{41}$

Another indication is Niccolò Stopio's remark in his letter to Hans Jakob Fugger of 15 June 1567, reporting on Strada's activities in Venice: 'Strada does not consort with sculptors here, but only with goldsmiths or engravers, or miniaturists, which is his business ('mestiere')'42 Clearly Strada profited from his trips to Venice to commission the desired woodcuts and engravings for the voluminous illustrated books he projected. The quantity and quality of the illustrations he envisaged presuppose a considerable time for their realization, both because good engravers may have been rare, and because Strada would not have the capital to pay for all of them at once. We know that the illustrations for Serlio's Settimo Libro Book were engraved in Venice, as were those for the Sesto Libro, which would never be actually published. It is conceivable that images for some of his other projects were likewise commissioned during his visits to Venice.

Such commissions of course involved a lot of preparation. Strada had to provide a carefully drawn exemplar of each illustration for the engravers. This he cannot all have done himself during his short and busy sojourns in Venice, so these were probably prepared beforehand, both by himself and by assistants he employed in his studio, among whom his two elder sons Paolo and Ottavio. Since he presented these illustrations as scientific documents, such assistants must have worked from Strada's own sketches, and in any case under his close supervision.

The same holds for the texts of the various books. These were not all written or even edited by Strada himself, but of course a definitive reading of the texts needed to be provided: Ottavio's 1574 letter, discussed above, documents the care taken with the texts and the translations of the Serlio volumes. For

41 Lodovico Castelvetro, Poetica d'Aristotele vulgarizzata, et sposta per Lodouico Casteluetro, in Vienna d'Austria, per Gaspar Stainhofer, 1570. Reputedly Maximilian II himself had supported its publication (Marchetti/ Patrizi 1979), and he may have appointed Strada to help Castelvetro realize it (even if only as an interpreter between author and printer). It is quite possible that Strada himself may have invested in the edition, which proved to be a bestseller, but in view of Castelvetro's heretical reputation he would not have wished that fact to be advertised. A subsequent, posthumous treatise by Castelvetro, the presentation of which by Castelvetro's brother Giovanni Maria is dated Vienna 15 January 1572, was printed by Strada's old associate Pietro Perna, as was the second edition of the Poetica itself (both under Perna's pseudonym Pietro de Sedabonis).

BHStA- $L A 4852$, fols. $35-36 f$.: 'Il Strada non pratica qui con scultori, se non con orefici o disegnatori di stampe in rame, o miniatori, che è il suo mestiere'. 
his other projects he likewise must have employed learned men to provide and correct the content for each book, and professional scribes to provide the fair copy for the typesetters. Strada's request to the Reichsvizekanzler, Johann Baptist Weber, for Imperial letters of recommendation for his printing projects includes an offer to have the book titles in each letter inserted by his own servant, which confirms his employment of at least one professional scribe. ${ }^{43}$ It is further corroborated by a request to Hans Jakob Fugger from Carolus Stephanus, one of his librarians, for a rise or, failing that, for some help or a recommendation to find a better job. Fugger was quite prepared to help him, and asked his other librarian, Wolfgang Prommer, for his comment and suggestions. Prommer explained that Stephanus hoped that Fugger would recommend him for a place as a clerk in the chancery of the Augsburg City Council; but if that was no option, at least 'to be recommended to Jacobo de Strada, where he intends to maintain himself with his wife and child by assiduous writing. ${ }^{4} 4$ Stephanus should not be confused with the well-known French physician Charles Estienne, though he may likewise have been a relative of the famous French printers Henri and Robert Estienne, who maintained contacts with the Fuggers. Certainly he was a learned man, who wrote good Latin. It is not known whether he did any work for Strada, but his request again confirms that Strada did indeed employ professional scribes and scholars such as Stephanus, and that these were sufficiently well paid to make such employment desirable. ${ }^{45}$

\subsubsection{The Polyglot Dictionary}

Strada himself explicitly speaks of the people he employed in at least one of his projects, the polyglot dictionary, in his letter of 28 December 1568 thanking Duke Guglielmo Gonzaga of Mantua for the patronage extended to his son Paolo. From this it appears that from a simple polyglot dictionary in the three classical languages it had developed into something much bigger:

43 Doc. 1573-06-oo (shortly before 6 June 1573): 'Se'l paresse alla Signoria Vostra che a cadauna lettera vi si metesse dentro questi titoli di questi libri, io li faria coppiare dal mio huomo, per non dar tanta fattica a quello che scrivera le lettere'.

44 'Mit einer Condition, vermaint er durch E.G. furbitt bey dem Herrn Stattpfleger Relingen zu promovirt werden, ob er mitterzeit In der Herren von Augspurg Canntzelley mechte gebraucht werden. Wa er dort nit vnder mechte Khumen, begert er auf das wenigist durch E.G. hülff bey dem Jacobo de Strada zu Commendirt werden, daselbs vermaint er sich mit stetigem schreiben kinde mit sampt seim weib vnd Kindt aufenthallten'. Hartig 1917(a), pp. 317-318 (Stephanus' request to Fugger, in Latin, undated, 1566); 318-319: Fugger's request for more information to Prommer); 319-320 (Prommer's point by point reply).

Ibid., pp. 229-230; doubtless thanks to Fugger's support Stephanus later was appointed an official notary, who was occasionally employed by the Fugger: thus he drafted the inventory of the library and collection of Raymund Fugger the Younger in 1576; ibid. p. 38, n. 1 . 
At present in my house is being written a Dictionary of 11 languages; that is an effort of mine that I have begun eighteen years ago, and for which I have always kept people in my service to write it. The languages are these: Latin, Greek, Hebrew, Chaldean, Turkish, Arabic, Persian, Spanish, French, German, and Italian; in which at the appropriate places I will insert the medals, marble statues, tombs, in short everything which can be shown in images. ${ }^{46}$

Already two years earlier he had described the project in detail to Adam von Dietrichstein, hoping that he would use his influence as Imperial ambassador in Spain to move Philip II to provide some financial support:

Since your departure here from Vienna, I have put together all the indices of this Dictionary, which take up eighteen volumes, similar to that of the letter A which Your Honour once saw in my studio. Now the first volume, the letter A, is being written; it is certainly quite delightful to see, both because of the many languages presented together, which are all written in their own characters, and for the images of the coins, the ancient statues, the funerary monuments in sculptured marble, the antique inscriptions and tablets, and everything whatever which can be shown by figures, and other things that I have brought together from all over the world, not without great expense. Every individual thing will have its explanation, which will be written in all of the languages mentioned $<\ldots . .>47$

Apart from demonstrating one of the uses to which Strada intended to put the material he had brought together in his Musaeum, these passages also show that he functioned as the editor-in-chief or the publisher, rather than as the author, of the Dictionary: he had worked out its concept, and had taken care to bring together in his library the sources necessary for the work, and the images that were to illustrate it, and now was carefully coordinating the production of the texts. Some of these he may have written himself, but most of the actual work was probably done by scholars and scribes he employed to this end. Some of these may actually have worked on a daily basis in Strada's Musaeum, but there is a good chance that many of the texts were requested and delivered by mail, especially when more recondite expertise was demanded. The work was actively supported by Maximilian II, who in the 1570 os would recommend Strada's efforts to raise funds for the completion of the project, and facilitated

$46 \quad$ Doc. 1568-12-28.

47 Doc. $1566-03-01$. 
Strada's work in other ways. When Strada requested the Emperor sometime in 1571 to instruct the ambassador in Constantinople to have a bundle of his texts translated into Turkish, Arabic and Persian, he was confident that this would be granted ${ }^{48}$ In a similar way Strada may have sent around the texts of his entries to various scholars contracted to provide correct translations.

\subsubsection{Caesar's Complete Works, Annotated and Illustrated}

It may be assumed that Strada occasionally or regularly employed scholars and artists in a similar way for his many other projects, for instance in translating Leandro Alberti's Description of Italy into Latin and in providing the supplements he planned to add to it. As we shall see below, the number and the character of the encyclopaedic compilations which Strada had available for publication by the mid-1570s indicate that work on these had steadily continued during the $1560 \mathrm{os}$. The first concrete piece of evidence of these is a copyright privilege from the French King Charles IX, which was granted to Strada on Christmas Day of 1572 . This apparently extended to a list of several planned publications, but it is known only through the text as included in Strada's 1575 edition of Caesar's Commentaries, and therefore only gives title and description of that one book. ${ }^{49}$

From this document it appears that the work as planned differed from the one eventually printed [Fig. 14.21-14.27]. In the first place, Strada intended the book to be bilingual, presenting the complete Latin text next to an Italian translation: the exact reverse of what he planned for Serlio's Settimo $\mathrm{Li}$ bro, where Serlio's Italian was complemented by a Latin translation. That he thus wished to cover a European, rather than a local market is evidence for

48 Doc. 1571-00-00.

49 Caesar 1575: 'Iaques de Strada Mantuan, antiquaire de l'Empereur nostre tres cher et tres amé beaupere et cousin, nous a fait entendrè qu'il desireroit volontiers faire mettre en lumiere les livres contenus en une feuille de papier à nous praesentee, et attachee sous le contreseel de nostre chancellerie. Desquels le premier est, un livre en langue italienne, ensemble avec la version Latine, intitulé en Italien, C. Iulij Caesaris rerum gestarum Commentarij XIv. Nempe: C. Iul. Ces. De Bello Gallico, Comm. viı. A. Hirtij. De eodem, Liber I.C. Iul. Caes. De Bello Civili Pompeiano, Comm. III. A. Hirtij De Bello Alexandrino, Liber I. De Bello Africano, Liber I. De Bello Hispanico, Liber I. Omnia collatis antiquis manuscriptis exemplaribus, quae passim in Italia, Gallia, et Germania invenir potuimus, doctè, accuratè, et emendatè restituta. Eutropij Epitome Belli Gallici, ex Suetonij Tranquilli monumentis, quae desiderantur. Cum doctiss. Annotationibus Henrici Glareani, Fulvij Ursini Romani, Francisci Hotomani, I.C. Aldi Manutij, P.F. <...>Donné à Paris le xxv. iour de Decembre, l'an de grace 1572 et en notre regne le xiii'. A cursory investigation of the relevant indices of the Archives Nationales in Paris suggests that both Strada's request and the original of the privilege were probably destroyed. I am grateful to Odile Bordaz to have guided me in this quick search. 
the scope of his aspirations as a publisher, and it indicates a wish to render his material accessible to as wide an audience as possible, or in any case to extend its audience beyond the humanist scholar to the educated reader whose Latin was weak or nonexistent. In the second place the published book, though lacking the Italian translation, was enriched by a set of woodcut illustrations and by a quantity of transcriptions of Spanish inscriptions not mentioned in the French privilege.

What is particularly interesting is that Strada's copyright privilege closely conforms to a book that was in fact published in Lyon a year before his own edition: this was likewise a complete edition of all of Caesar's Commentaries, supplemented by Hirtius' continuations and by comments by the contemporary scholars François Hotman, Fulvio Orsini and Aldo Manuzio the Younger, and lacking only the scholia to the Bellum Gallicum and the Bellum Civile by Henricus Glareanus. This volume does include a copyright privilege which is dated earlier than Strada's, but this only refers to Hotman's Scholia in
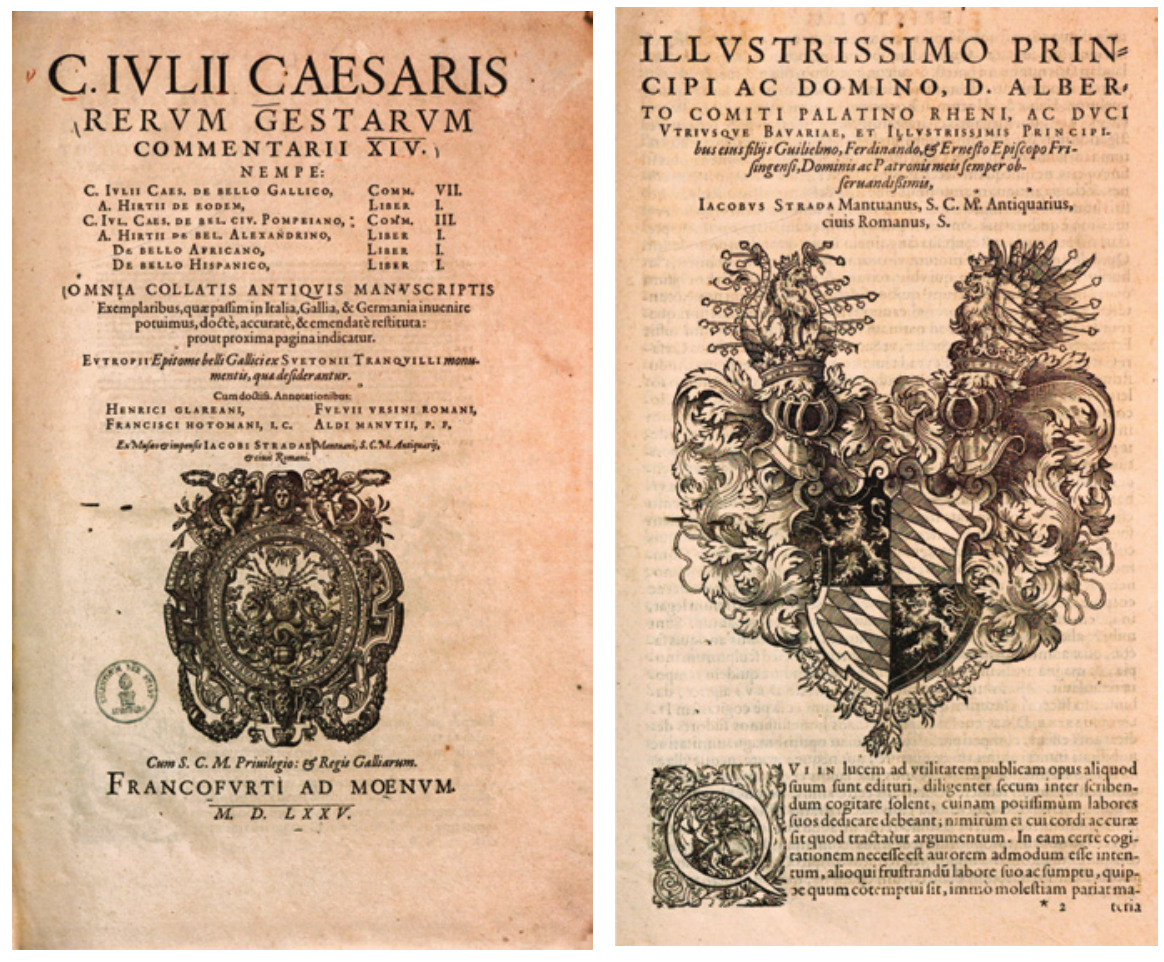

FIGURES 14.21-14.22

Strada's edition of Caesar's Commentaries, printed by Georg Rab in Frankfurt in 1575: titlepage and dedication to Duke Albrecht v of Bavaria. 

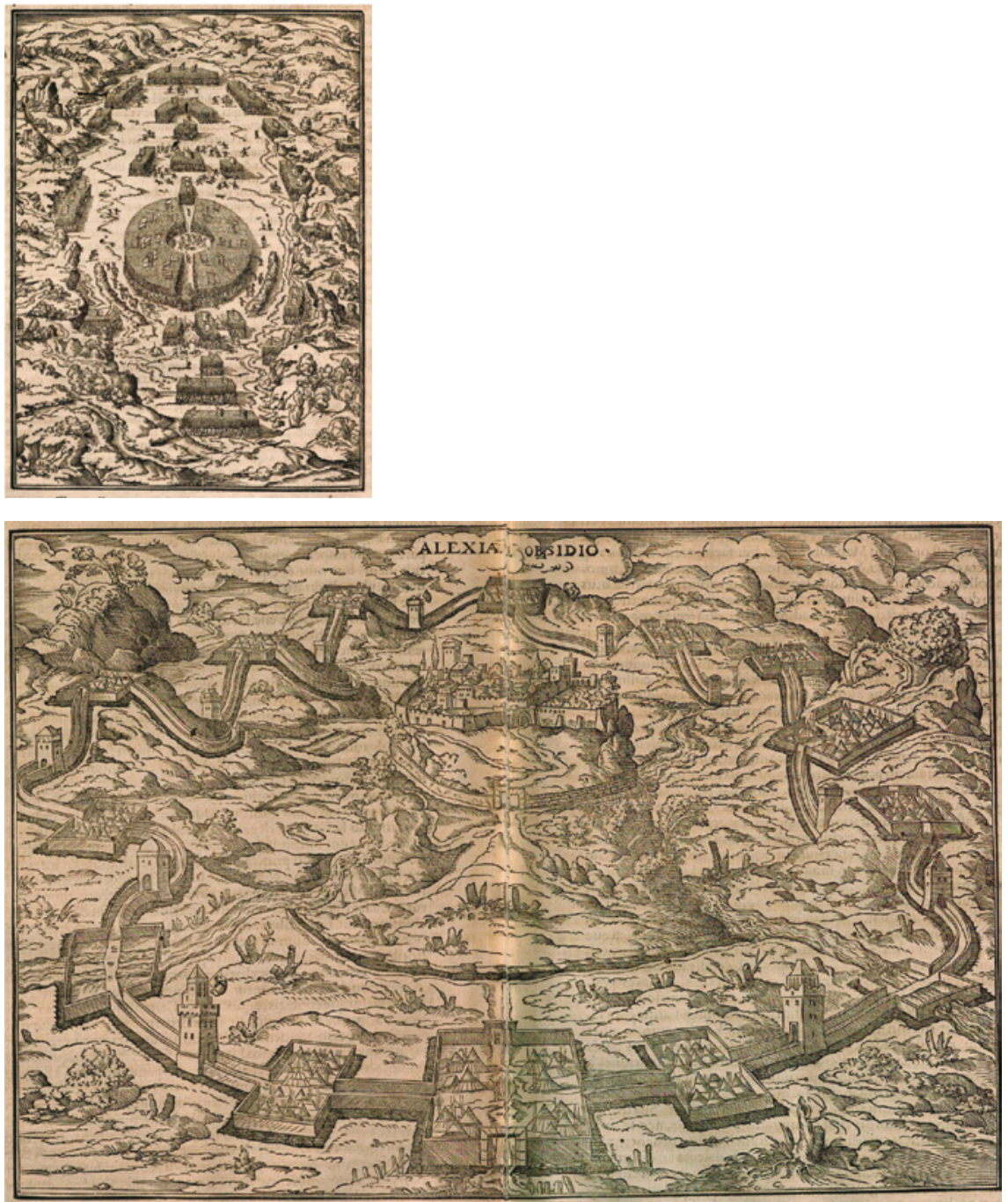

FIGURES 14.23-14.24 Woodcut illustrations from Strada's 1575 edition of Caesar's

Commentaries: pitched battle between the armies of Caesar and Ambiorix (p. 6o) and a double page bird's eye view of Caesar's siege of Alesia, defended by Vercingetorix (p. 100).

Commentarii Caesaris, that is to only one of the supplements of the actual volume. It is clear that Strada did not pirate this edition, since he already disposed of the supplements when he obtained the French privilege for his book long before the French edition was ever published.

It is difficult to understand exactly what happened. Maybe Strada obtained or even commissioned the supplements through one of his contacts-perhaps 

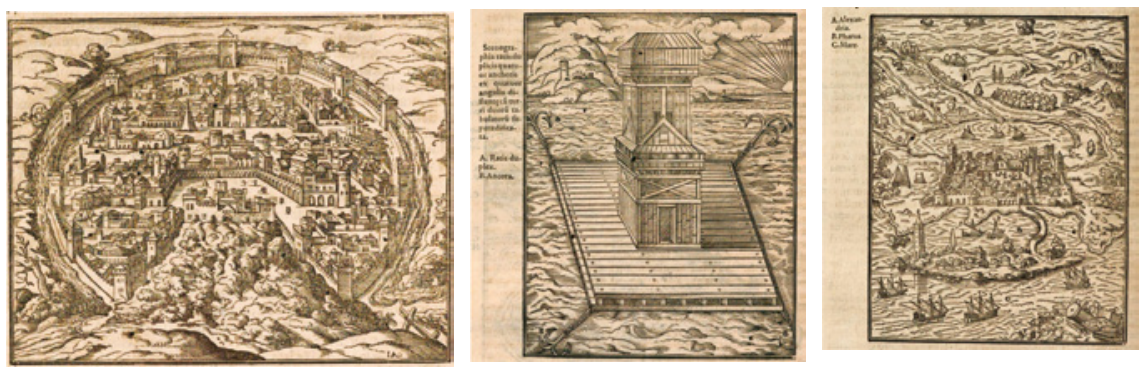

FIGURES 14.25-14.27 Bird's eye view of Vesontio (Besançon; p.14), a raft carrying a tower (p. 134) and a view of Alexandria (p. 200), woodcut illustrations from Strada's 1575 edition of Caesar's Commentaries.

Reichart Strein von Schwarzenau, who had been a student of both Glareanus and Hotman - and later came to some agreement to divide the market with the printer Barthélémy Vincent, whom he may well have known personally since his sojourn in Lyon. ${ }^{50}$ If so, the book was nevertheless no co-production: though both included woodcut illustrations, of which no mention is made in the respective privileges, these are of different subjects. Whereas Vincent added some naturalistic and technical illustrations to the general alphabetical index of the volume, Strada added some thirty reconstructions of Caesar's battles and sieges at the apposite places in the text itself. These had at one time been commissioned, from an unnamed architect, by Ferrante Gonzaga, Signo$r e$ of Guastalla, Viceroy of Sicily and a general of Charles v. Strada probably had acquired them from Ferrante's son, Cesare, with whom he was in contact in the 156os [Figs. 14.23-14.27]. ${ }^{51}$

\subsubsection{The Copyright Privilege of 1574}

As could be expected, Strada's book as published more closely conforms to its description in the Imperial copyright he was accorded by Maximilian II on 30 May 1574 [Figs. 14.21-14.27]. This privilege is an important milestone in the development of Strada's editorial project: apart from the Caesar (nr III.) and

$5^{0}$ Vincent also was the publisher of Jacques Besson's Theatrum instrumentorum et machinarum of 1578, which owns much to the same sources on which Strada's own Desseins artificiaulx [Strada 1617-1618], was based, and the style of its illustrations (though not their subjects) are very similar; though published in two volumes only by Strada's grandson Ottavio 1617-18, a manuscript version of Strada's treatise probably antedates Besson's publication by some two decades; cf. Marchis/ Dolza 2002. 
Serlio's Settimo Libro (nr I.), both of which would actually be printed in 1575, the privilege mentions five other works. ${ }^{52} \mathrm{Nr}$ II. is Serlio's reconstruction of the Roman Castra as described by Polybius and an adaptation 'ridotta in una cittadella murata', and complemented by a treatise on warfare by the French general Guillaume du Bellay. ${ }^{53} \mathrm{Nr}$ IV. is a corpus of ancient inscriptions 'collected from all over the world, in Latin, Etruscan, Greek, Arabic, Chaldean' reproduced and explained in seven volumes. ${ }^{54} \mathrm{Nr} \mathrm{V}$. is a book which masks as an album of ancient Roman equestrian statues, 'both male and female.'55 This might indeed have included images directly derived from the Marcus Aurelius on Capitol Hill and from Roman relief sculpture, but the description rather suggests that it consisted largely of prints after contemporary designs for festival costumes in the antique manner, such as designed by Strada and his colleagues at the Imperial court. That this was indeed the case is confirmed by the recent identification of a volume of festival designs from Strada's workshop in the Kupferstich-Kabinett in Dresden, the title of which is identical to this item. ${ }^{56}$

52 Doc. 1574-04-30. The Serlio and Caesar volumes are described as follows: 'I. II settimo libro d'architectura di Sebastiano Serglio Bolognese, nel qual si tratta di molti accidenti, che possono occorrer al architetto in diversi luoghi et istrane forme de siti e nelli restauramenti o restitutioni di case, e come habbiamo a far per servirci degli altri edifici e simili cose, come nella sequente pagina si lege. Nel fine vi sonno agiunti sei palazzi con le sue piante et fazzate in diversi modi fatte per fabricar in villa per gran prencipi del sudetto authore, italiano et latino'; 'III. Cai Julii Caesaris commentariorum libri viII, quibus adiecimus loca precipua delineata, in quibus ipse Caesar castrametatus est adversus varias gentes, ex antiquissimo codice manuscripto, quos nunc primum in lucem damus cum doctissimis Henrici Glareani annotationibus, tam latino quam italice'.

53 Ibid: 'II. Castrametatione dei Romani prima nel modo, che essi accampavano per tende et padiglioni, dimostrata et dipoi ridotta in una cittadella murata per Sebastiano Serglio Bolognese, designata fuora del sexto libro di Polybio historico, italiana et latina, nel cui fine ne habbiamo gionto l'instrutione sopra Ii fatti della guerra, descritta dal signor Gulielmo de Bellai, signor de Lange, francese e latina'.

54 Ibid:: 'Iv. Antiquarum inscriptionum, quae toto fere orbe Latinae, Hetruscae, Graecae, Arabicae, Caldeae in marmoribus aut aereis monumentis sculptae caelateve fuerint et Hieroglyphicis notis signatae, tomi Septem'.

55 Ibid:: 'v. Equestrium statuarum tam virorum quam mulierum formae elegantissimae una cum vestimentis ipsorum ac artificiosissime pictis et arte Phrygionica ingeniöse elaboratis, quibus olim induebantur, item cataphractorum equorum cum eorum phaleris ornatissimis, quemadmodum olim Romani et Graeci in bellis atque etiam pompis publicis et ludis curulibus circensibusque usi sunt, iuxtaque ipsos satellitum precedentium quoque eiusmodi vestibus indutorum formae; his quoque larvarum atque vestimentorum histrionicorum, quibus antiquitus in tripudiis et saltationibus noctu utebantur, varia genera adiuncta sunt'.

Discussed above, Ch. 4.3.5. 
In his letter to his father of November 1574 Ottavio Strada repeatedly refers to such a book of 'mascare', which he thought would sell well, but the book was never published in the form envisaged, though a number of woodcuts by Jost Amman for its illustrations were in fact executed and printed, some of which at least based on Jacopo's own designs [above, Figs. 4.23-4.25].57

The last two works mentioned in the privilege were dedicated to numismatics: nr vi. presented a series of coins of all Roman, Byzantine and German Emperors and their various family members, and to which Strada added those of the Ravenna Exarchs and the Lombard kings of Italy. It was basically intended as a conventional though relatively complete 'Bildnisvitenbuch', a picture book in which the images of each personage were accompanied by only the briefest potted biographies or 'elogii'.58

$\mathrm{Nr}$ VII., on the other hand, was a much more ambitious work: probably an evolution of the numismatic corpus described in Strada's $155^{6}$ privilege, it provided full biographies of all these same Emperors, their relatives, usurping tyrants, exarchs and so on, each of which was to be followed by a complete survey of the coins struck during their reigns..$^{59}$ These illustrations were based on the numismatic material Strada had collected during his travels, which he had had carefully engraved in copperplate, rather than in woodcuts as in his

57 Cf. above, Ch. 4.3.5.

58 Doc. 1574-04-30: 'VI. Series imperatorum Romanorum ac Graecorum et Germanorum a Caio Julio, Cai filio, Cai ne pote, caesare usque ad Maximilianum II. caesarem pium felicem augustum una cum liberis patrinis atque matrinis ex aureis, argenteis, aereis numismatibus quam fidelissime delineatis; inservimus etiam iuxta tempora exarchos et Longhobardorum reges omnesque cum ipsorum elogiis breviter descripsimus'.

Ibid.: 'VII. Vitae imperatorum Romanorum, item Contantinopolitanorum et Germanorum omnium, qui fuerunt a Caio Julio, Cai filio, Cai nepote, Caesare usque ad Maximilianum II. Imperatorem, Caesarem Pium Felicem Augustum, cum omnibus eorundem uxorum, filiorum et consanguineorum historiis. Attulimus quoque vitas universorum eorum tyrannorum, qui diversis in mundi partibus Romanum imperium vi vel fraudibus sibipsis subiicere conati fuere. Insuper ad illustrationem horum omnium vitas etiam eorum exarcharum posuimus, qui sedes atque habitationes suas Ravennae, urbe nobilissima Italiae, habuerunt. Tomi viII. Posuimus in cuiuslibet imperatoris vitae fine numismata ea, quae de illo passim per hunc orbem terrarum nos videre atque invenire potuerimus quaeque vel in Italia vel in aliis similibus provinciis tum etiam in Graecia ex auro, argento, aere excussae fuere, ita nimirum, ut ea primo quidem summa fidelitate, imitatione et diligentia ad unguem et ad similitudinem verorum antiquorum delineanda, deinde autem in tabulis aereis pulchre excidenda typoque demandanda curaverimus, item in fine harum tabularum cuiuslibet etiam numismatis descriptionem anneximus. Tandem finitis hisce omnibus habes quoque fastos et annales consulatuum cuiuslibet imperatoris, ut nimirum sie, quid quilibet imperator, quolibet anno et tempore patraverit, tanto rectius cognoscere queas, ubi tamen maioris doctrinae et testimoninii gratia similiter et inscriptiones antiquas, quae in marmoribus et tabulis aeneis incisae et sub nominibus eorundem imperatorum appositae fuerunt, diligenter adiunximus etc'. 
1553 Epitome thesauri antiquitatum [above, Figs. 14.6-14.9]. It is likely that at least a part of the engraved images included in Ottavio Strada's posthumously published De Vitis Imperatorum printed in Frankfurt in 1615, which is similar but less ambitious in concept as his father's project, were printed from plates commissioned by Jacopo in the 1560 os and 1570 os [cf. Figs. 14.6-14.9]. Unlike Ottavio's volume, Jacopo's corpus moreover was intended to include detailed descriptions of each coin, as well as the other material sources for the gestae of each prince as documented in the Fasti capitolini and other documented inscriptions.

Strada's 1574 copyright privilege gives some indication of the direction and the scope of his ambition as a publisher. All works listed are related to the history or the arts of classical Antiquity, though some of these, such as the Serlio volumes, are geared towards contemporary use of the antique example or precept. Most of them are exhaustive, of an encyclopaedic character; all of them are directed towards a literate, but not necessarily a purely academic audience. Certainly they were directed at a prosperous audience, since none of them can have been cheap: they are all huge volumes, folios or ample quartos, some of them in many volumes. Perhaps their most important common characteristic is that each and all of them were to be provided with ample illustrations. This would have made them more expensive, but also more attractive to the wealthy clientele envisaged, yet only the Serlio volumes, the Equestrium Statuarum and the Series Imperatorum can be imagined to some extent as Renaissance equivalents of the coffee-table book. Strada's insistence on including such visuals aids rather reflects his conviction of the value of the image-and therefore of drawing and design, the art of making images-as a source of information and expertise, of knowledge. This conviction he had shared with or even contributed to Hans Jakob Fugger and his circle; Fugger's former librarian, Samuel Quiccheberg, codified it in his treatise on the science of collecting, the Inscriptiones vel tituli Theatrum of 1565 , and a year later Strada himself expressed it in his 1566 letter to Adam von Dietrichstein cited earlier: 'for truly, your lordship, by drawing one comes to know an infinite variety of things, and one's judgment becomes more excellent on all subjects. ${ }^{6}$

\subsubsection{Printing in Frankfurt}

Some time before requesting the copyright privilege, in March 1574, Strada told Hans Jakob Fugger that he planned to send his son Ottavio Strada to Venice 'per alcuni miei negotij', offering to have him execute any commissions for Fugger. Possibly Strada's private business was connected with the acquisition of further antiquities and works of art: he offered to have Ottavio collect information

6o Quiccheberg 1565; Doc. 1566-03-01. The theme is treated above, Chs. 11.6 and 13.9. 
for Duke Albrecht about the Vendramin and Mocenigo collections that were on the market. But since at the beginning of this same letter Strada told Fugger that he had decided to try and sell both his house and his studio, with everything in it, this seems unlikely. ${ }^{61}$ It is much more probable that Ottavio was sent to Venice to start negotiations with the Venetian printers and to commission illustrations for the several planned books from some of the famous Venetian woodcutters and engravers. There seems little doubt that Strada originally planned to have his books printed in Venice, for shortly after having obtained the copyright privilege he not only requested and obtained a further, general privilege for all the books and images he had collected and wished to publish in future, but also asked for permission to travel to Venice 'in order to have his books printed', as well as a passport and letters of recommendation to the Doge and the Signoria. ${ }^{62}$ Strada opted for Venice probably both because of the stature of Venetian humanist printing and the quality of its engravers, but his wish to print some of his books in Italian must have been an additional motif. Ottavio's troubles in Frankfurt with the text editing and proofreading of Serlio's Settimo Libro show that printing serious works in Italian was not as yet common in Germany, and far from simple:

It is quite something that in Germany, where there are no Italians, someone is printing Italian [books]; if Wechel had not accepted to print, you wouldn't have found any opportunity here, and certainly would have wasted your time in wanting to print Italian in Germany, where there is no one [to assist in that]: you would not believe how few learned men there are in Frankfurt. ${ }^{63}$

So there must have been serious reasons for Strada to abandon his project to print his books in Venice and to choose Frankfurt instead: perhaps German printers were cheaper, or perhaps he thought he would have less competition for his type of books in Germany; certainly the Frankfurt book fair must have provided a strong attraction. The suddenness of his decision in favour of Frankfurt, however, suggests that it may have had to do with a failure to obtain a safe-conduct from the Signoria that would protect him against the Papal Inquisition. ${ }^{64}$

61 Doc. 1574-02-01.

62 Doc. 1574-00-00.

63 Doc. 1574-12-05 (transcribed in Appendix A).

64 When Strada returned to Venice in 1568 , after his precipitate flight from the Papal Inquisition in Mantua the summer before, he took great trouble to obtain an Imperial safe-conduct, and through Maximilian's intervention, a similar guarantee from Duke Guglielmo 
Whatever may have been the reason, it is clear that when Strada in August prepared to send Ottavio to Frankfurt, it was explicitly to occupy himself with the printing project. ${ }^{65}$ As we have seen, Ottavio's report to his father of the end of the year bears this out: it gives a good impression of the many different negotiations the complexity of his father's ambitions involved him in. The letter, which appears to reflect point by point his father's lost letter, indicates that Ottavio was fully in his father's confidence, had discussed the many aspects of the various projects with him in detail, and had contributed his own ideas and opinions. It appears that, whereas his father supplied the intellectual concept and the idealistic drive for the project, Ottavio contributed a more level-headed, more business-like and realistic approach, and had an open eye for the potential market. Thus he was well aware of competing projects, advising against reprinting the Epitome thesauri antiquitatum in a German edition because that had already been done by others, but also noting that the edition of Caesar's Commentaries that Andrea Palladio was preparing posed no threat, because that would be of a different character than the edition planned by Strada, with different images, and he believed their own book would be more beautiful than Palladio's and could be offered at a lower price. ${ }^{66}$ Apart from books soon to be published-Serlio's Settimo Libro and the Caesar editionand other works mentioned in the copyright privilege, another two projects are discussed, a book on the history of the Popes, which was to be illustrated by coats of arms and was probably intended as a pendant to the Lives of the Emperors mentioned in the copyright privilege. Strada had asked the help of Giovanni Battista Fonteo, an Italian humanist active at the Imperial court, to complete the histories and to obtain drawings of the coats of arms. ${ }^{67}$

Another interesting project mentioned is an illustrated Bible, the images for which were to be designed by one 'Jan Baptista', probably Strada's Mantuan associate Giovanni Battista Scultori, though Ottavio cautioned his father

Gonzaga of Mantua to protect him from interference by the Holy Office. It is not clear whether this was actually given, and Strada appears in fact to have abandoned a planned trip to his hometown [Docs. 1568-01-29; 1568-01-30; and 1568-10-11]. Though Strada did request a passport and Imperial letters of recommendation to Venice in 1574, it is not clear whether he actually travelled there.

65 Strada asked Maximilian for a passport for Ottavio for Frankfort, and that he was (nominally?) appointed a servant of the Emperor; the passport was conceded, the appointment apparently not [Docs. 1574-08-00; 1574-08-09].

66 Doc. 1574-12-05, transcribed in Appendix A.

67 Ibidem; Giovanni Battista Fonteo is chiefly known because he wrote the cartels for Imperial jousts designed by Arcimboldo and some texts explaining Arcimboldo's composite portraits; but he also wrote a history of the Cesi family of Bologna; see Kaufmann 1978(a), p. 276 . 
to limit the commission to simple sketches, which then could be engraved by Jost Amman in Nuremberg, 'because for small images there is no one better than Jost Amen. ${ }^{68}$ Ottavio employed Amman also to carve the woodcut illustrations for the book of 'mascare' already mentioned, images of figures in costumes all'antica designed for court entertainments such as masques and tournaments. ${ }^{69}$

\subsection{Financing the Programme}

\subsubsection{Princely Support}

Ottavio explicitly related the programme of books to print to the annual calendar of the world of the book, the Frankfurt book fair:

And God willing after the present fair we should have the book of festival costumes printed, and the German version of Serlio's book; and while these are in press I will have the Castrametatio translated into Latin, and will try to have the arms of the Popes ready. And we need to try to bring out at least a couple of books at every fair, and we must have patience for at least two fairs before we will gain something from these; after which we will have greater ease to do other things. ${ }^{70}$

This makes clear that Strada's publishing ambitions were not a mere side-line: as well as an attempt to divulge information which Strada thought of importance, it must be considered as an ambitious business enterprise. Possibly he was inspired by the example of the Lyon marchand-libraires, the Venice printing house of Aldus Manutius and the Antwerp printer Christophe Plantin, examples which must have made him think it possible both to publish his books and to make a solid profit on them. However mistaken he may have been in

68 Doc. 1574-12-05, in Appendix A. It would be worthwhile to investigate how this project ties in with the many other illustrated Bibles produced both in France and in Germany around this time, with illustrations by, among others, Bernard Salomon and Jost Amman, who were both employed by Strada himself at various times.

69 On the book of festival designs see above, Ch. 4.3.5.

70 Doc. 1574-12-05, Appendix A: 'Et a Dio piacendo dopo questa Fiera stampando questo libro delle mascare, et il libro del Serlio in dotesco. Et mentre che si stampino questi dui libri farò tradur la Castrametation in Latino, et cercarò di far le arme delli Papi. Et bisognara cercar de meter al manco hogni Fiera un par di libri in luce. Bisogna che noi habiamo pacientia per due Fiere avanti che si caverà qualche cosa; dopo se haverà meglior commodità di far altre cose'. 
this, his conviction was such that from about this time onward a great part of his energy was invested, not only in finishing the works he intended to include in his programme, but also to bring together the funds needed to cover the necessary initial investments.

In this he first of all reckoned on his most important patron, Emperor Maximilian II. The first instance of this is Strada's request presented to Maximilian sometime before 30 June 1573. In this he described his corpus of inscriptions in seven volumes, and the first volume, the letter $\mathrm{A}$, of his polyglot dictionary. ${ }^{71}$ He then explained that he wishes to print these books, but that he lacks the necessary funds, so he asks the Emperor for 'un buon aiuto di costa', a subvention to enable him to bring out his books with dedications to Maximilian and his sons. Strada was realistic enough to realize that the Emperor could or would not cover such expense all by himself, so in one breath he asked for letters recommending his project to other potential sponsors: the councils of the free Imperial cities and the most prominent Princes of the Empire. ${ }^{72}$ To speed up his request, which was supported by Reichart Strein von Schwarzenau, Strada added his own concept of the letter of recommendation, the titles of the books involved carefully copied out. The requested letters were duly made

71 Doc. 1573-06-oo: 'Mi trovo sette gran volumi scritti di lettere maiuscule, parte latine e parte greche, dove sonno tutte le inscriptioni antiche, che in varie parte del mondo si trovano; e perchè sonno molti anni che io le ò messo insieme, imperò con hanimo di publicarle sotto il nome della Sacra Cesarea Maestà Vostra alla stampa a commune utilità di ciascheduno. Son anche al fine della lettera A del mio Dictionario delle xi lingue, le quali sonno queste: Latina, graeca, hebraea, chaldaea, spagnuola, francese, tedescha, bohema, hyllira, cioè chiavona [sic], et italiana. Vi sonno in questo libro d'hogni sorte di medaglie et antiquità in dissegno, si come la Sacra Cesarea Maestà Vostra à visto nel mio studio ultimamente, le quali vanno poste ciascheduna al suo luogho'. It is interesting to note that the eleven languages of the dictionary are not always the same, those of the Slavic territories under Maximilian's rule for this occasion supplanting the Arabic and Persian mentioned elsewhere (cf. below). Doubtless Turkish would have been the eleventh language, omitted apparently by mistake.

72 Doc. 1573-06-oo: 'Sacra Maestà, io voria far stampar questi libri in Francoforte, ma la mia bursa è troppo picolina alla grande spesa che vi andara. Suplisco la Maestà Vostra che non mi voglia abandonare di un buona aiuto di costa, acciò si possino publicare questi libri sotto al felicissimo nome Suo, et delli Serenissimi Suoi figliuoli. Overo, se la Maestà Vostra non mi vol dar aiuto di danari, suplisco quella mi voglia dar aiuto con lettere, scritte di buono inchiostro, alle città libere e franche che qui sonno sotto nominate, cioè una lettera per cadauna città: Ratisbona, Nurimberga, Augusta, Ulma, Francoforte, Spira, Argentina, Wormatia. E perchè l'aiuto di queste sudette città non bastaranno, suplisco Vostra Maestà Cesarea apresso una lettera a cadauno di questi Principi qui sotto nominati, cioè l'Altezza del Principe Ferdinando et il Principe Carlo, et l' Excellenza del Ducha di Baviera, et delli sei Elettori, con questi tre Vescovi apresso: Passa, Wirzpurg, et Pamberg'. [added in margin: Salzburg]. 
out on 30 June. ${ }^{73}$ In September of the same year Strada followed this up by a request for similar letters of recommendation to several Italian princes and city states which again were duly conceded. ${ }^{74}$

It is not clear whether this exercise did bring in any serious money. There was at least some response: thus Ottavio could receive a subvention of 40 Gulden in aid of his father's planned book granted by the Nuremberg City Council. ${ }^{75}$ It appears that Ottavio was sent to travel around to follow up Maximilian's request, and to receive any bounty conceded. The initiative seems to have yielded few concrete results: Strada's only known thank-you letter dates only from September 1575, though this relates to a quite substantial amount of 500 Thaler, granted by the Elector August of Saxony. ${ }^{76}$ But Strada himself may not have known which Princes and Imperial cities had responded favourably to Maximilian's recommendation, because Ottavio appears to have kept back for himself the moneys he was delegated to receive on behalf of his father. That, at least, is the first of his alleged crimes listed in Strada's will of 1584, which excluded Ottavio almost entirely from his father's succession. If true, this would explain why Strada thanked the Elector August for his bounty only in 1575, when he may have heard of his gift through other channels (perhaps Hubert Languet or the Saxon representative at the Imperial court). ${ }^{77}$ But these allegations, to which

73 Doc. 1573-06-oo; Strada also offered to send his own scribe to insert the titles of the publications into the letters, or to provide many copies of a separate enclosure as were required. But in a post-script he also asked the Vice Chancellor of the Holy Roman Empire, Johann Baptist Weber, that the letters should be written with a carefully adjusted pen and in good ink. The recipients were to be all the Electors, the Archdukes Ferdinand and Karl, the Prince-Bishops of Salzburg, Würzburg, Bamberg and Passau and the Duke of Bavaria; and the cities of Augsburg, Ulm, Nuremberg, Regensburg, Frankfurt, Strassburg, Speyer and Worms. In the definitive version [Doc. 1573-06-30] the list of recipients as given in Strada's request was extended to the Prince-Bishop of Freising, the Duke of Jülich, Duke Julius of Braunschweig, Margrave Georg Friedrich of Brandenburg, and Duke Johann Friedrich of Pomerania.

74 Doc. 1573-09-0o and 1573-09-30; recipients were the Dukes of Savoy, Ferrara, Mantua, Florence, Parma and Urbino, and the Senates of the city-states Venice, Lucca, Genoa and Milan.

75 Doc. 1573-11-07; it may well be that Strada's personal connection with Nuremberg's patrician families - suchs as Willibal Imhoff-counted as much as Maximilian's recommendation in obtaining this subvention, which was granted and paid out to Ottavio Strada only 'uf sein vaters weiter schreiben', i.e. after Strada had provided some additional information.

76 Doc 1575-09-28: 'Gnedigster Churfurst, ich hab mit groser danksagung die 5oo dhaler emphangen, die mir Eur C.F.G. gepresentiert hatt, auf Ir Röm. Kay. May. schreiben zu hulf meines Dichsionarium'.

77 Doc. 1584-07-01 (Appendix B); Strada claimed that Ottavio had kept the moneys he received for himself: 'Erstlichen, demnach mier durch genedigiste Bewilligung des Römisch Khaijserlichen Majestäts Maximiliani Secunti ein Anzall commendatorij Briefe, zu Hülff 
I will come back below, must be taken with a grain of salt. It is far more likely that among these patrons there was in fact little concrete ambition to further Strada's projects, the scope of which carried a big risk of failure with it. Strada's later correspondence with his Italian patrons, though dealing with several of his projects, never refers to his 1573 request for funds, much less to any subventions actually received. Surely it is significant that Maximilian II himself appears not to have provided any concrete financial support. ${ }^{78}$

\subsubsection{Attempts to Sell House and Collection}

While visiting Prague sometime in the summer or early autumn of 1573, Strada communicated the disappointing results of his initiative to his patron, Vilém z Rožmberk. Coming back to this in a letter written shortly before Christmas, he announced that he now had decided to sell his collection and his library, as well as his house, in order to be able to finance the printing of his books. Strada first offered it all to Rožmberk, both because of 'der alte Kundschaft' , his longstanding and continuing patronage, and because at an earlier time Rožmberk had expressed interest in the house. Strada offered it to him for eight thousand Thaler 'though it has cost me more than nine thousand'. For the 'Kunstkammer' and the 'Liberey' he referred to the inventory and pricelist he had given Rožmberk on the occasion of an earlier visit to his house; and he was rather sanguine as to his reaction, because he expressed the hope that his patron would accept the offer before the end of January, so that Strada could take the cash with him on his planned trip to Venice in February $1574 .{ }^{79}$

meiner Buechdruckhereij, an die Chur und Fürstten, auch andere Stände des Heiligen Römischen Reichs, verferdiget; dieselben ich durch in Octavium lassen praesentiern, hat er alles Gellt sovil ime verehrt für sich behalten, mier oder der meinen Heller werdt nicht davon folgen lassen; da doch der Churfürstten von Sachsen mier allein fünffhundert Thaller verehrt, daher leichtlich zu schliessen und zu vermuedten, was ime von zwaintzig Briefen zuverehren von andern möge erfolgt sein'. It seems odd that the Elector should have waited for almost two years to respond to Maximilian's recommendation.

78 The accounts of the Hofkammer make no mention of any 'aiuto di costa' Strada may have received for this purpose.

79 Doc. 1573-12-18: 'Weyder so wert sie Euer Gnaden wol haben zu erinern, wie ich bey Euer Gnaden zu Prach bin gebesen, unndt ich Dero angezagt hab von den vir Schreyben, die mir Ir[?] Röm[isch] K[ayserliches] May[estät] geben hat on die Corfirsten mit samt den Reysstetten von wegen meiner Biecher, unndt ich nicht underlassen hab kinnen Euer Gnaden anzuzagen, wie das dieselbige Schreyben wenig Nutz gebracht haben unndt [ich] nichts ausgericht hab und von allen Leytten verlassen bin. So bin ich bezwungen, meine Kunstkamer mit der Liberey, wies Euer Gnaden gesehen haben, unndt mit samt dem Haus, zu verkaufen, unndt mit dem selbigen Gelt meine Piecher druken lassen. So hab ich nit underlassen kinnen Euer Gnaden, als meinem gnedichen Herrn, zum ersten die Sach zu offerieren, und zu wissen thuen, wo Sie ein Lust hetten zu meiner Kunstkamer 
Strada's optimism was misplaced: considered as an investment in real estate his house turned out to be a failure, and he would continue his unsuccessful attempts to convert it into ready money for the rest of his life. Rožmberk appears not to have risen to the bait, for in a letter to Hans Jakob Fugger of 1 March of the same year Strada proposed the house as a suitable residence for Prince Ferdinand of Bayern, Duke Albrecht's second son, who was rumoured to come and spend a few years at the Imperial court; but this offer again yielded no positive response. ${ }^{80}$ In November 1575 Strada approached Elector August of Saxony. After thanking him for the subvention he had been given for the polyglot Dictionary, and presenting him with a set of copies of Titian's portraits of the first twelve Roman Emperors in return, Strada continues with a glowing description of his Kunstkammer and his library. He then presents its key to the Elector, thus symbolically presenting its contents, and begging him to accept it in exchange for a modest annual pension to maintain himself and his children, which would enable him to continue the Dictionary in Saxony. Again, there is no evidence that August seriously considered this proposal. ${ }^{81}$

An explicit refusal of Strada's offer, if any, must have been couched in friendly terms, if Strada a year later seriously expected August might employ him as an architect. That was the reason why early in September 1576, at the Imperial Diet at Regensburg, Strada presented a request to Maximilian, asking him for letters of recommendation and a passport to Saxony. But in the same request he also asked the Emperor to instruct his son Rudolf, King of the Romans, of Hungary and of Bohemia, to suggest to the Bohemian Estates that they present him with Strada's library, to serve as a royal library in Prague castle. He moreover begged Maximilian to ask Vilém z Rožmberk to intercede with the Estates to pay Strada a decent sum for it. In the letter he does not mention his printing ambitions as his motive, but refers to the load of debts he had accumulated both in Vienna and in Frankfurt, the latter of which must have been largely due

mit samt dem Haus, so wolt ichs Euer Gnaden vil lieber verginnen, unndt auch wolfalar geben von Wegen der alten Kundschaft unndt deglige Dienst die mir Euer Gnaden thuen, der kainem Firsten, er sey gleych wer er wel; unndt ichs wol Euer Gnaden verginnen mecht, die weyl Euer Gnaden vormals mirs angebotten hatt, wo ichs verkhaufen wolt Eyer Genaden'.

80 Doc. 1574-03-01: ' ... non posso mancare di avisarLa qualmente io mi son risoluto di voler vender tutto il mio studio, con hogni qualunque cosa che n'è dentro; voglio anche vender la mia casa, et perchè già fu detto qui che Sua Excellenza voleva mandar il Ducha Ferdinando a star qualche anni apresso Sua Maestà, creddo che non potria trovar allogiamento il più commodo della mia casa, perchè in essa vi sonno xii stufe con tutte le altre commodità che si puole immaginare'.

81 Doc 1575-09-28; Strada's connection with the Elector of Saxony discussed in Lietzmann 1997 . 

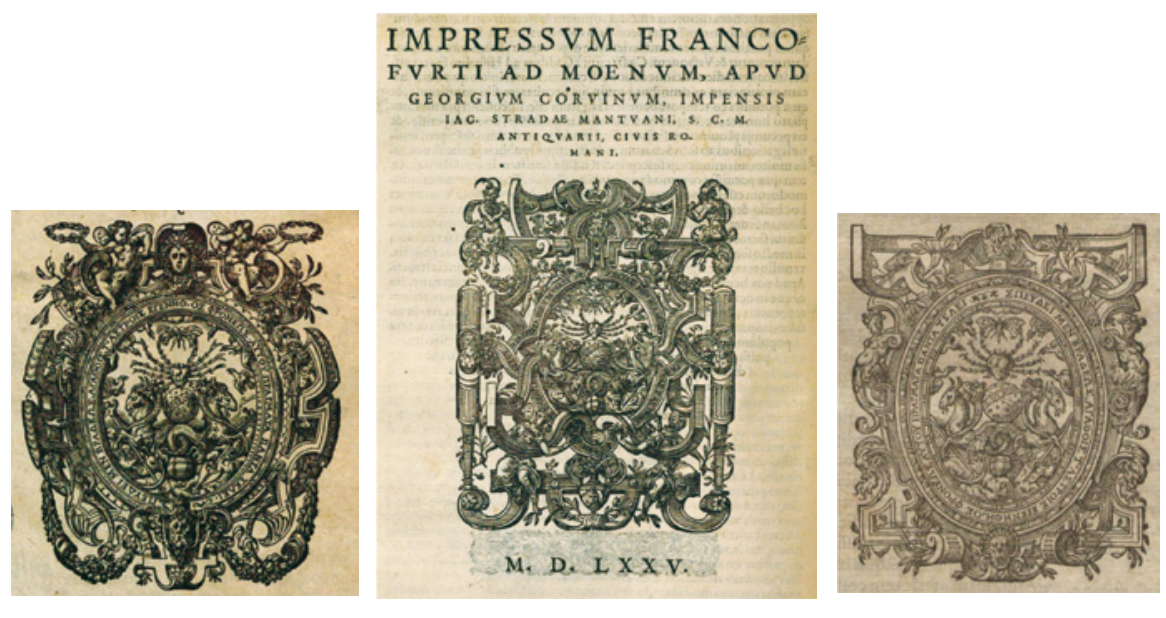

FIGURES 14.28-14.30 Strada's three different printer's marks, on the title page and the colophon of his editions of Caesar's Commentaries, printed by Georg Rab (Corvinus) in Frankfurt in 1575, and on the title page of Serlio's Settimo Libro, printed by Andreas Wechel, Frankfurt 1575 .

to investments in his publishing projects, such as those described in Ottavio's letter. $^{82}$

This creative solution was not very realistic; in any case Maximilian's Privy Council decided not to discuss it, though Strada was granted the requested letters of recommendation to August of Saxony. ${ }^{83}$ Strada must have reckoned with a refusal to his proposal, for in the same request he also proposed an alternative: he asked to be allowed to institute a lottery, in which his house and his collection, which together he valued at a total of seventeen thousand Thaler, would be the prizes. By selling lottery tickets he hoped thus to realize a sufficient sum to be able to pay his debts and to continue printing his books. ${ }^{84} \mathrm{He}$

82 Doc. 1576-o9-oo: 'Suplisco Vostra Maestà Cesarea che mi voglia concedere una lettera alla Maestà del Serenissimo Re di Romani, che Sua Maestà domandi in dono la mia libraria con hogni cosa che vi è dentro, a li Signori Bohemi, et sia messo nel Castello per dellettatione di Sua Maestà. Anche una lettera al Signore di Rosenberg, che ne voglia trattare con essi Signori che mella paghino, et io cenne farro buon mercato, perchè mi bisogna far danari della mia robba, per qualche verso per pagare li mei gran debiti ch'io ò a Francoforte et Vienna, che né in l'uno, né in l'altro posso più tornare se non porto denari'.

83 Doc. 1576-09-03. Strada also obtained recommendations to August from Hubert Languet and Vilém z Rožmberk (Docs. 1567-09-07 and 1576-10-31; cf. Lietzmann 1997, p. 398).

84 Doc. 1576-o9-0o: 'Et in casu che Vostra Maestà Cesarea non mi voglia concedere queste lettere su nominate, La suplisco almeno che mi concedi una licenza di fare un lot, cioè metter alla ventura tutta la mia robba, casa, et il mio studio, con hogni cosa che vi è dentro. Et la casa mia sia fatta buona diecimilia taleri per il manco, perchè mi costa più a me et ora volendola fabricare, molto più costaria; et il studio sette milia, che tutta la summa 
had premeditated this idea, for already in June he had, through his old friend Jacopo Dani, achieved that Grand Duke Francesco of Tuscany addressed a letter to Maximilian II supporting this initiative. ${ }^{85}$ The proposal was in fact not unusual: to make a 'Glückshafen' of (part of) one's possessions, to entrust them to Fortune or 'mettere a la ventura', was a not uncommon form of doing business. ${ }^{86} \mathrm{~A}$ later letter to Dani explains that opposition in Vienna frustrated Strada's plans; nevertheless in 1578 Strada repeated his request directly to the Estates of Lower Austria, who, after having passed it on for consultation to Archduke Ernest, answered again with a firm refusal a year later. ${ }^{87}$

\subsubsection{Ex Musaeo et Impensis Jacobi Stradae}

When Strada realized that his attempts to obtain direct subventions from patrons would not be sufficiently successful to continue printing after he had realized his first two projects, Serlio's Settimo Libro and Caesar's Commentaries,

montaria dicesette milia talleri, et oltre ad hogni spesa; et la lettera della licenza sia scritta di modo che nel regimento né quelli di Vienna, né altri mi possino impedire questo mio negotio'.

85 Doc. 1576-06-16: 'Ora, Signor Secretario, creddo che Vostra Signoria si riccordi et abbia alla memoria il mio Dictionario delle lingue, che già sonno xxv anni ch'io vi lavoro atorno, con molti huomini che scrivino in varie parte le lingue che vi entrano. Signor, per la grande spesa et per esser quattro anni ch'io non posso avere li mei avanzi dalla Corte, tanta mia fattica et spesa rimane in pendente, et hoggi o dimane ch'io mi moia li mei figliuoli non sonno abili a farlo finire. Io per non intralassare tal opera et non potendo esser pagato dalla Corte, me ò volsuto valere del mio, et ò volsuto vender la mia casa, la quale mi costa oltre x milia talleri, et Sua Maestà Cesarea la lauda per la più bella che sia in Vienna, ma non ò trovato compradore. Solum mi rimane una speranza sicura di farne danari con farne un Lot, cioè metterla alla ventura con tutta la mia robba al prezzo che farra stimata. La causa che mi move a chiedere la lettera a Sua Altezza si è perchè saro presto ispedito, et s'io la chiedessi a Sua Maestà saria mandata per via d'un consiglio a un altro, et forse mi si lassaria adietro o per malignità o nigligenza di qualche secretario. Vostra Signoria sa 'l costume della nostra Corte, e tanto più ch'io non sono tedesco, si che Vostra Signoria la intende; et la lettera di Sua Altezza sarra subito mandata al Singor Cancelliere, et ne faro spedito imediato'. Strada added a model for the Grandduke's letter, explaining the procedure: 'Egli dessidera da Vostra Maestà Cesarea una licenza di pottere far un lot, cioè metter alla ventura tutta la sua robba, case, studio, et hogni sua facoltà a quel prezzo che sarra stimato dalli architetti et servidori di Vostra Maestà Cesarea'. A note in Dani's hand in the margin, 'Si manda la lettera in bona forma' indicates that the letter was written.

86 Welch 2008.

87 Doc. 1577-10-04(c), Strada to Jacopo Dani: 'La lettera di Sua Altezza che mi mandò Vostra Signoria non fece frutto niuno, perchè subito quelli del paese non volsero aconsentire a Sua Maestà Cesarea, dicendo non volere aprir tal strada, si che patienza. Si che Vostra Signoria vede la morte del mio padrone à fatto si che tutte le mie fattiche anch'elle son morte; et staranno morte per insino che qualche Principe le farra resussitare et stampare...'; on the later request, see Docs. 1578-03-17 and 1579-04-07. 
both published in 1575, he began to look for other means. Doubtless he had tried to interest professional publishers and printing houses to go shares in the investment needed, but it is not clear whether he was successful in this. The Caesar edition, printed by Sigmund Feyerabend's business partner Georg Rab (Corvinus), mentions the latter's name only in the colophon, which may indicate that he was not financially involved: its title page and its colophon present Strada's two printer's marks and both state that he had borne the printing costs: 'Ex Musaeo et impensis Jacobi Stradae Mantuanae, S[acrae]. C[aesareae]. M[aiestatis]. Antiquarij, et civis Romani' [Fig. 14.28-14.29].

On the other hand the printer of Serlio's Settimo Libro, Andreas Wechel, probably invested in it, since it is his name that is given in the impressum, though again title page and colophon are decorated with two versions of Strada's printer's mark [Fig. 14.30]. ${ }^{88}$

It can be concluded that Strada's projects were not commercially viable and could not be printed without subventions from wealthy patrons. Though there is no evidence that Maximilian contributed, Strada later claimed that he had intended to do so and had actually commanded Strada to discuss his project with the Hofkammer, but that his sudden death in October 1576 interrupted these negotiations. Be that as it may, it is certain that Maximilian's protection and his recommendation were of great value and that his death was a huge setback for Strada's projects. ${ }^{89}$ In consequence Strada attempted to interest other Princes to take his projects under their wing, more often implicitly, but sometimes explicitly, such as when he offered Grand Duke Francesco of Tuscany some of his works to be printed at a press he had heard the Grand Duke intended to set up. Dani's notes indicated that the formal reply informed Strada that there was at the time no press operated on behalf of the Medici Grand Dukes, but that he was free to have his books printed at his own expense by one of the printers active in Florence, such as the Giunti or 'Maestro Giorgio

88 On Corvinus, who had come to Frankfurt recently and worked in partnership with the Frankfurt printers Sigmund Feyerabend and Weygand Han, see Klöss 196o; on Wechel, see Evans 1975 .

89 Doc. 1577-10-04(c), Strada to Jacopo Dani: 'Si che Vostra Signoria vede la morte del mio padrone à fatto si che tutte le mie fattiche anch'elle son morte; et staranno morte per insino che qualche Principe le farra resussitare et stampare'; Doc 1581-01-04, Strada to August, Elector of Saxony: 'La M.C. mio padrone, che in Gloria, Max[imilia]no ne provisse più volte, che quando io volevo cominciar a far stampare, che S.M.C. mi voleva provedere alla spesa di quello facevo di bisogno, et di questo io ne dovvevo trattare con la camera, che di tutto ne haveria provisto al bisogno. Hora, Exc. Sign., quand'io volsi<...>cominciare a mettere ad esecutione questo negotio per stampare; io in stesso andai a Ratisbona a trovare S.M.C. la quale M. mi comandò che dovesse de l'tutto dar informatione alla Camera; et mentre si trattava questo negotio, S.M.C. morse'. 
francese', that is Georges Marescot, who had taken over the printing house of the heirs of Lorenzo Torrentino in ${ }^{564}$. Strada made a similar, though less concrete suggestion in a letter of the same date to Duke Alfonso II of Ferrara. ${ }^{90}$

\subsection{The Index Sive Catalogus}

\subsubsection{The Document}

Some years later, in a letter to Jacopo Dani of November 1581, Strada sent a list of works he intended to have printed in Frankfurt and offered to dedicate one or more of these to the Grand Duke. In the beginning of the same year Strada had made a similar, but more concrete proposal to the Elector August, to whom he had sent a copy of the same list of works. ${ }^{91}$ The list sent to Florence

90 Doc. 1577-10-04(d), Strada to Grand Duke Francesco: 'Serenissimo Signor, ho inteso come Vostra Altezza vole che si rimetti in piedi la Sua belissima stamparia, et dar opera che si stampino libri non più stati visti. A questo io ne posso far offerta delli mei, li quali qui sotto nominaro; che per la morte del mio padrone son rimasto anch'essi morti per insino a tanto che'l Signor Iddio li provede $<\ldots>$ [sums up a number of titles] $<\ldots>$ Molte altre cose mi truovo che saria troppo lungo a volerle tutte nominare. Il mio Padrone ne havea già pigliato la protetione, che si cominciassino a stampare; et a me havea fatto carico ch'io facessi venire lettere et stampatori da Parisi. Ma la morte à guasto hogni cosa, si che se Vostra Serenissima Altezza volesse far questo benefitio al mondo, et lassar immortal nome et gloria di Lei con il fargli stampare, tutto sta in quella'. Dani's note jotted in the margin of Strada's letter to himself (cited in the preceding note): 'Et quanto alli suoi libri, [the Grand Duke] non ha di presente stamperia propria, ma vi sono in Fiorenza quella de' Giunti et di M[aest]ro Giorgio francese a quali li potra far stampare da se'. On Marescot, see Franco Pignatti, 'Marescotti, Giorgio', s.v. in DBI 70, 2007; Doc. 1577-10-04(b), Strada to Alfonso II, Duke of Ferrara: 'Ma la morte del mio Padrone a causato che li mei libri con tutta la speranza a presso è anchor lei morta, patienza; et cossì staranno per fino a tanto che qualche Principe gli farra ressusitare, et finire per lei [?]. Suplisco Vostra Altezza che ci voglia far sopra qualche pensiero, et qui fargli vedere da Signor Suo Ambassador, che si potriano esser più presto di Vostra Altezza che di altro Principe che viva; ma La suplisco bene che questo rimanghi apresso di Lei<...>'

91 Doc. 1581-11-02, Strada to Jacopo Dani: 'Io voglio in Fran[cofor]te far stampare le vite di tutti li Imperatori latini, graechi et germani, in lingua latina, li quali saranno parecchi volumi; et a cadauno Imperatore vi voglio nel fine della sua vita porvi tutte le sue medaglie; et di già se intagliano in rame qui in casa mia. Voria pregar la Signoria Vostra che con qualche occasione Vostra Signoria mostrasse Lei questo inventario di questi libri a Sua Altezza (li quali tutti se anno da stampare), et fargli offerta, se quella havesse accaro che qualche d'uno gli fosse dedicato, ch'io lo faria molto voluntieri, et mi saria summo favore'; Doc. 1581-01-04, Strada to August, Elector of Saxony: 'Mando a V. Alt un catalogo di libri scritti a mano, li quali son tutti in casa mia, et la maggior parte sonno in punto per metter alla stampa, et no[n] è coppia fuori in luocho alcuno $<$... $>$ quellla [= Elector August] puol 
has been preserved, the one sent to Dresden doubtless was a copy of the same list, the heading of which clearly states its character and function:

Index or catalogue of the books that I, Jacopo Strada, in part composed myself at my own initiative, in part had composed and written [by others] at my commission and expense, and finally in part acquired and purchased by other means.

This Index exists in several copies, of which the versions sent to Florence and Dresden are the earliest that can be dated by their context [see Appendix D]. But it was drafted much earlier, perhaps already as early as 1576 , when Strada discussed his projects with Maximilian II, certainly before August 1578, when Strada paraphrased a substantial part of its contents in his proposal to the Antwerp printer Christophe Plantin. It has been preserved in several, almost identical copies. After the first forty-nine items listed in all of these, what appears to be the earliest copy continues with a list of hundred and fifty-one miscellaneous volumes of manuscripts, including over five hundred individual titles. For that reason the Index sive catalogus has been often interpreted as a 'catalogue' of Strada's library. Considering that it is a list of books in his collection, that view is not completely without foundation. But if so, it would only represent a fraction of Strada's library, which, according to himself, counted over three thousand printed books in addition to his manuscripts. It seems more likely that this second part of the Index represents manuscripts that Strada offered for sale to potential patrons.

The first part of the document, listing forty-nine items, certainly was offered to Strada's patrons: apart from the Elector of Saxony and the Grand Duke of Tuscany, the Elector Palatine was probably one of its recipients. ${ }^{92}$ But Strada offered the titles listed in it not for purchase, but explicitly as works which he intended to have printed, soliciting financial support from his patrons in exchange for the dedication of the relevant item. This may seem odd in the case of one or two of the treasures described, such as the huge bird's eye view of Rome - 'a thing, by Hercules! worth contemplating' — which Strada had commissioned from 'that excellent Netherlandish painter' (item 16) or a similar image of Cairo, which Strada had copied from an old painting preserved in the

vedere questo mio Indice (o Catalogo) di sudetti libri, li quali M[ae]s[tr]o Elias Hutter, su nominato, a visti in buona parte, et egli ne potra dare a V. Alt. piena informat [ion] $<<\ldots>$ '. cV. 10117; SLA, Magistratstestamente nr. 104; Firenze, ASF, Carte e spoglie Strozziane, I, f. 308, c. 64-69 (the copy sent to Jacopo Dani in 1581); Rome/Città del Vaticano, Vatican Library, Cod. pal. 1919 (copy probably sent to the Elector Palatine Friedrich III or Ludwig vi). 
Gonzaga palace of San Sebastiano at Mantua (item 17 ) ${ }^{93}$ It is equally odd in a case such as the Koran written in golden script and splendidly illuminated that had reputedly belonged to Mustafa, Suleiman the Magnificent's eldest son who was strangled as a result of his stepmother Roxelana's palace intrigue (item 26). Such splendid objects may well have been included mostly because of Strada's pride in having obtained them, and perhaps partly in the hope that one of his patrons would make a substantial offer for one of them. Yet in view of the high quality he envisaged for some of the other items he certainly did intend to have printed, it cannot be excluded that even for Prince Mustafa's Koran he had some sort of luxury printed reproduction in mind, something akin to a modern facsimile edition: after all he knew 'of no book that for elegance can be compared with this, such is its beauty and excellence, so that it equals precious stones'.

Moreover almost all the other items included in the list were intended to be printed, as is clear from their descriptions, which give information on their contents, but sometimes also on their status of completion, and in how far the illustrations had already been finished and engraved. This latter fact is of importance, because the common characteristic of almost all of the items included in the Index is that Strada intended to illustrate them profusely. In many cases the images were in fact the raison dêtre of the work, as is the case for the various 'tabulae' listed in the Index. Doubtless these were intended to be printed on separate sheets which the buyer could at will have bound in a book, have pasted together on a linen support, as was the custom for geographical maps (a good solution for the bird's eye's views of Rome and Cairo and for the view of the Castrametatio of Suleiman the Magnificent at his siege of Vienna (items 11, 12 and 8), or formed into a rotulus: a good solution for sets of images of the Columns of Trajan, Marcus Aurelius and Theodosius, the frieze of the Camera degli Stucchi in the Palazzo del Te (items 37, 40, 41 and 42), and the various images documenting how the Sultan, his suite and his army set out for his campaigns (items 10 and 11 ).

93 It has been suggested above (Ch. 2.3) that Strada may have known Hermannus Posthumus and perhaps Maarten van Heemskerck in Rome in the 1530s; Posthumus afterwards came to Mantua, and later worked in Landshut, an itinerary close to that of Strada himself. Manuscript material from Strada's collection to some extent relates to the Heemskerck and Posthumus material (the Berlin sketchbooks). Posthumus' well-known painting Tempus edax rerum now in the Liechtenstein collection provides some inkling of what Strada's commission may have looked like. On the Cairo painting, see Brown 1984; Bourne 2001, p. 108. Strada may have been inspired by the earlier huge woodcut image of Cairo engraved by Giovan Domenico Zorzi and published with an accompanying description by Matteo Pagano in Venice in 1549, the whole edited with a full-size facsimile reproduction in Warner 2006. 


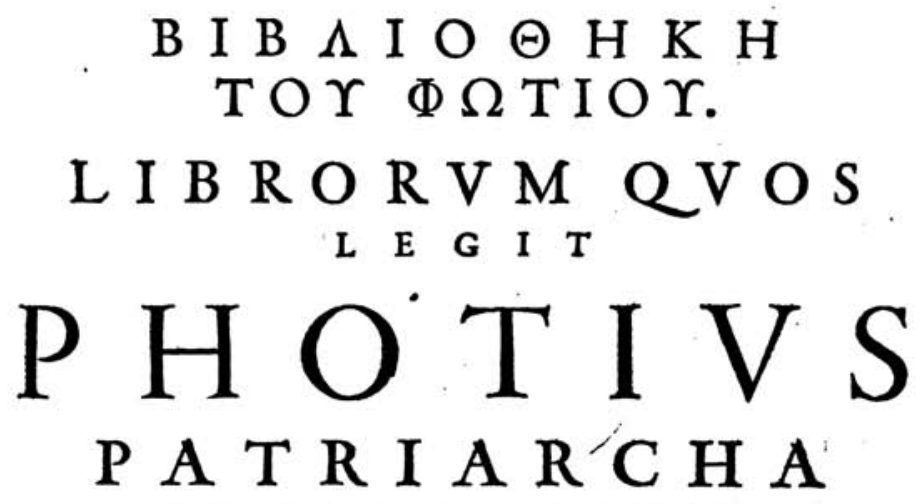

E X CERPTA ET CENSVRAE.

\author{
Quatuor mff.codicibus \\ Ex Gracia, Germania, ftalia, Gallia collatis.
}

DAVID HOESCHELIVS A G VSTANVS, primus edidit. Notis,in quibus multa veterum fragmenta, ante hac inedita, illuftrauit.

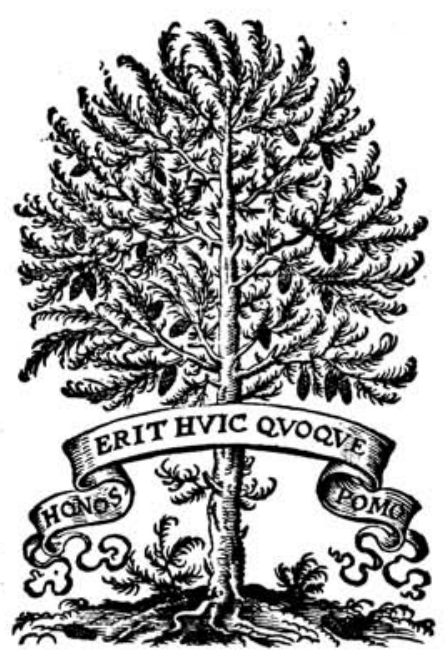

A V G V S T AE.VIN DE L I C OR V M A D I N S I G N B P I N V s.

Cum Priwilegÿs S. C E S. MAI E ST. \& Chriftianiß. Regis Galliarwm Augsburg 1601, edited by David Höschel. This is a collection of resumés and reviews of 278 mostly Greek books, many of which have been lost since. Strada intended to publish an edition of this text. 
The Index sive catalogus is a very important document, not only for its information on the holdings of Strada's Musaeum, as discussed in Chapter 13, but also because it provides the complete and final summary of Strada's publishing project. It was this document he sent to potential sponsors, it was this document he paraphrased in his letter to Plantin, and most significantly, it was this document that he appended unchanged to his will, charging his heirs and his executors to realize this specific programme. It took him about fifteen years since his first publications to establish this final programme, so it was well-considered, and must reflect both his own tastes and convictions, and his perception of what was feasible, considering the patronage available and the demand in the marketplace. The results of his efforts demonstrate that this perception was overly optimistic; yet a brief survey of the programme will be useful in providing a more clear idea of Strada's tastes, convictions and ideals.

The contents of the Index sive catalogus corresponds closely with Strada's interest as we have seen them in discussing his earlier career and his collections: its principal components are antiquarian, artistic and historical materials, to which are added a number of projected publications on similar aspects of the Ottoman Empire. Strada's library was very large and covered all faculties and disciplines, and doubtless he provided his patrons with literature in all these fields. But in the Index popular subjects such as theology, medicine, jurisprudence, even classical literature are conspicuously absent. It is clear that Strada did not intend to set up a sort of general publishing house, but explicitly specialized in the few fields of his own expertise. In the following the document, the text of which is annexed in Appendix D, can only be briefly surveyed.

\subsubsection{The Dictionarium XI Linguarum}

The principal works listed, and with which the Index opens, are huge compilations of antiquarian material: inscriptions, coins and other remains from the ancient world. Though no classical texts are included as such, nevertheless the philological aspect is present in the most ambitious work in the whole list, the Dictionarium XI linguarum, a profusely illustrated polyglot encyclopaedia that has already been discussed above (Ch. 14.5.2). In its description in the Index sive catalogus Strada explicitly points out that its entries are all based on the phrases provided by the 'best received authors' of classical Antiquity or, as he wrote to Grand Duke Francesco I: 'all these languages are presented according to the phrases of [= as found in the works of] Cicero and other learned men'.94 Such interest in language and correct usage was only natural, since it

94 Doc. 1577-10-04(d): ‘Tutte queste lingue si parlano secondo le frases di Cicerone et altri huomini dotti'. 
immediately reflected the practice of the humanist scholars with whom Strada rubbed shoulders at least since his intimacy with Hans Jakob Fugger and his circle, and some of whom he employed in the actual writing of these entries. The continuous labour on this huge project is directly reflected by item $\mathrm{nr} .27$ in the Index sive catalogus: a set of Arabic, Turkish and Persian dictionaries in manuscript. ${ }^{95}$

The encyclopaedic, comprehensive character of the Dictionarium XI linguarum and of several other works mentioned in the Index reflects the ideas of Fugger and his circle, as does the one bibliographical work included. This is a planned edition in two volumes of the Bibliotheca or Myrobiblion of the Byzantine scholar St. Photius, Patriarch of Constantinople (ca 810-893 AD), a compilation of summaries and critical reviews of Greek Classical and Patristic texts that is of the greatest importance, because many of the works treated in it have since been irrevocably lost. Strada's project (item 21) antedates the editio princeps [Fig. 14.31] of this important text by about a quarter of a century. ${ }^{96}$ The complicated history of this edition (Augsburg 1601) and of the manuscripts on which it was based, is exhaustively treated in a five hundred-page study by Luciano Canfora. It was the fruit of a subversive collaboration between David Hoeschel, a Protestant humanist from Augsburg, and Andreas Schott, a highly learned Flemish Jesuit, who a few years later also published the first Latin edition. ${ }^{97}$ Though Canfora does refer to the transcript of the Venetian manuscript in Fugger's possession — possibly provided by Strada—he makes no reference to Strada's project. This was at least partly based on Fugger's transcript, which Strada borrowed shortly before Fugger's library was transferred to Munich. Strada's project may have been a collaboration with his Vienna colleague,

95 Since these are of different sizes, Strada describes the objects as he had acquired them, rather than a hypothetical manuscript readily edited for the printer, and they will not have been among his priorities.

96 Strada's letter to Grand Duke Francesco I of Tuscany shows that he was well aware of the importance of this text: 'Poi mi truovo una Bibliotheca Greca scritta anticha, che sonno dui gran volumi, dove qui vi si trovano infiniti nomi di authori che da noi son mai stati uditi né nominati, et a libro per libro parla molto distinto quello che cadaunno di loro anno scritto' (Doc. 1577-10-04(d)).

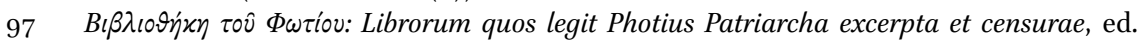
David Hoeschel (Augs-burg: 16o1); Photii Bibliotheca. Sive Lectorum à Photio librorum Recensio, Censura atque Excerpta, Philologorum, Oratorum, Historicorum, Philosophorum, Medicorum, Theologorum / è Graeco Latine reddita, Scholiisque illustrata, ed. Andreas Schott (Augsburg: 16o6); both books were printed at the same press, and dedicated to the same patron, Marcus Welser; cf. Reynolds/Wilson 1991 p. 321; Canfora 2001; Dickey 2007, pp. 103-104; Völkel 2010, pp. 298-299; Ferber 2010, pp. 412-416. 
Johannes Sambucus, whose work on an edition of Photius' Bibliotheca at this same time is discussed by Canfora. ${ }^{98}$

Heading the Index sive catalogus, the Dictionarium XI Linguarum is obviously the work by which Strada set most store, and in the composition of which he had heavily invested. Basically it should be considered as an illustrated encyclopaedia of the ancient world, comparable to similar antiquarian projects such as those planned by the Academia Vitruviana in Rome in the 1540 and 1550s, and Pirro Ligorio's manuscripts. Like those it illustrated the individual entries by relevant texts and images of coins, inscriptions, monuments and so on. In covering eleven languages its scope was even larger than these other projects, which likewise were never completed, let alone published. When Strada described his project in the index, about a quarter of a century after he had begun it, he had just about reached the letter B. The complete letter A took up 'sixteen huge folio volumes containing 2,500 folii, written on both sides in
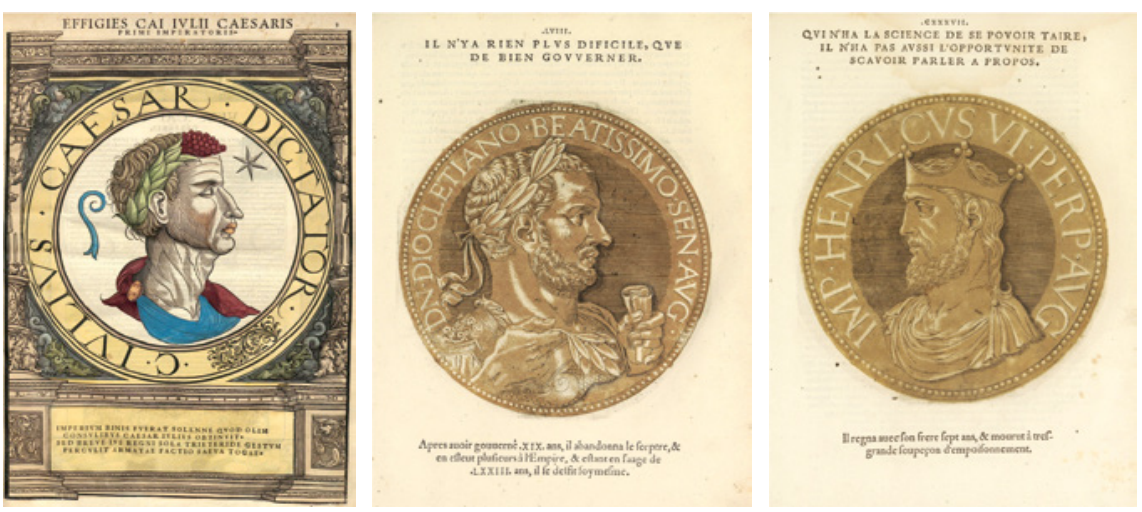

FIGURE 14.32

Julius Caesar, woodcut by Hans Rudolf Manuel Deutsch the Younger (ornamental frame) and Rudolf Wyssenbach (the portraits), from Jacopo Strada, Imperatorum Romanorum omnium orientalium et occidentalium verissimae imagines, Zürich (Andreas Gessner) 1559, a pirated edition of Strada's Epitome thesauri antiquitatum, Lyon 1553.

FIGURES 14.33-14.34 The Emperor Diocletian and the Holy Roman Emperor Henry vi, chiaroscuro woodcuts from Hubertus Goltzius' Les images presque de tous les empereurs depuis C. Julius Caesar jusques a Charles.v. et Ferdinandus son frere, pourtraites au vif, prinses des medailles anciennes $\langle\ldots$.. Antwerp 1557 .

98 Canfora 2001, Ch. XI, 'Zsamboky', pp. 85-90; a note in a catalogue by the Munich librarian Wolfgang Prommer documents Strada having borrowed the transcript from Fugger's library: cf. Hartig 1917, p. 116, n.1. 
a very small letter'. In his letter to Plantin Strada concedes that it would be difficult to have this actually printed, but he suggests that an edition of his Index to the entire Dictionarium might be feasible. This Index is the second item listed in the Index sive catalogus, and by itself took up sixteen folio volumes of 3,506 sheets in all, again written on both sides, in two columns, in a small letter. Referring to a book of which only a minimal part was as yet existent, this Index, on which Strada and his assistants had laboured for eleven years, probably should be considered as his plan for the Dictionarium as a whole, an inventory of the terms which were to be included and of the relevant materials available. ${ }^{99}$

Since the material, if still existent, has not as yet been identified, it is difficult to judge its character and its quality. Perhaps one should consider the Dictionarium XI linguarum as a huge illustrated encyclopaedia, giving full excerpts of source texts and editorial comments, whereas its Index would have been limited to the terms, their translations, and brief source references (both to texts and images). In his letter to Plantin Strada compares it to the concordances of Plantin's polyglot Biblia Regia. Probably it looked like—and could be used as—a 'normal' dictionary. ${ }^{100}$

\subsubsection{Other Antiquarian Works}

Basis for the content of the Dictionarium XI Linguarum was the antiquarian information Strada had brought together in the course of his career, and which he had codified in two corpora which in the Index sive catalogus immediately follow the Dictionarium and its indices. Item 3 consists of seven volumes of inscriptions, carefully reproduced, including the surrounding ornament 'exactly as they are in the marbles, stones and tablets themselves'. Strada precisely

99 According to Strada's letter to Adam von Dietrichstein of March 1566 he had finished this Index already by that time; but there he mentions that it took up eighteen volumes, rather than the sixteen mentioned in the Index sive catalogus. (Doc. 1566-03-01). Perhaps this indicates that he had had prepared a fair copy for the typesetter at some point. On the other hand the letter to the Grand Duke Francesco of October 1577 also mentions eighteen volumes (Doc. 1577-10-04(d)).

100 Doc. 1577-10-04: 'Li Indici del mio Dictionario qualli sonno XVI. volumi, nelli quali contengano tutto quelle che si truova nelli buoni authori Latini Greci et Hebrei et Caldei, con tutto quello che si truova nei marmi antichi di figura et de Inscriptioni et di Medaglie, et di hogni qualunque cosa che si puole mostrare à viva ò in dissegno; questi Indici che li stampasse di lettera minuta in tre colonne giudico saria come son le concordantia della Biblia del Plantino. Questi Indici è cosa maravigliosa à creddere che non li vede; perche tutto quello ch' l'huomo si puote immaginare è qui anottato et cittato il luogo dove si lege ò vero si vede; da tutti gli huomini dotti che l'hanno visto è stato giudicato ch' se mai si stampasse saria il piu util libro che si potesse desiderare'. 
sums up the number of inscription included in each volume: the first six volumes reproduced a total of 5,718 inscription found in Europe, Asia minor (e.g. Turkey and the Eastern seaboard of the Mediterranean) and Egypt, whereas the seventh volume was a miscellaneous volume dedicated to the Urbs, the city of Rome itself.101

Item 4 complements the epigraphic corpus with a numismatic corpus, consisting of eleven volumes describing nine thousand antique coins: this can be identified with Strada's A(ureum) A(rgentum) A(eneum) Numismatwn

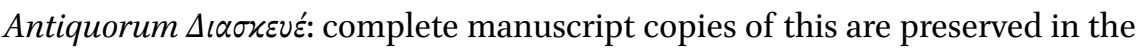
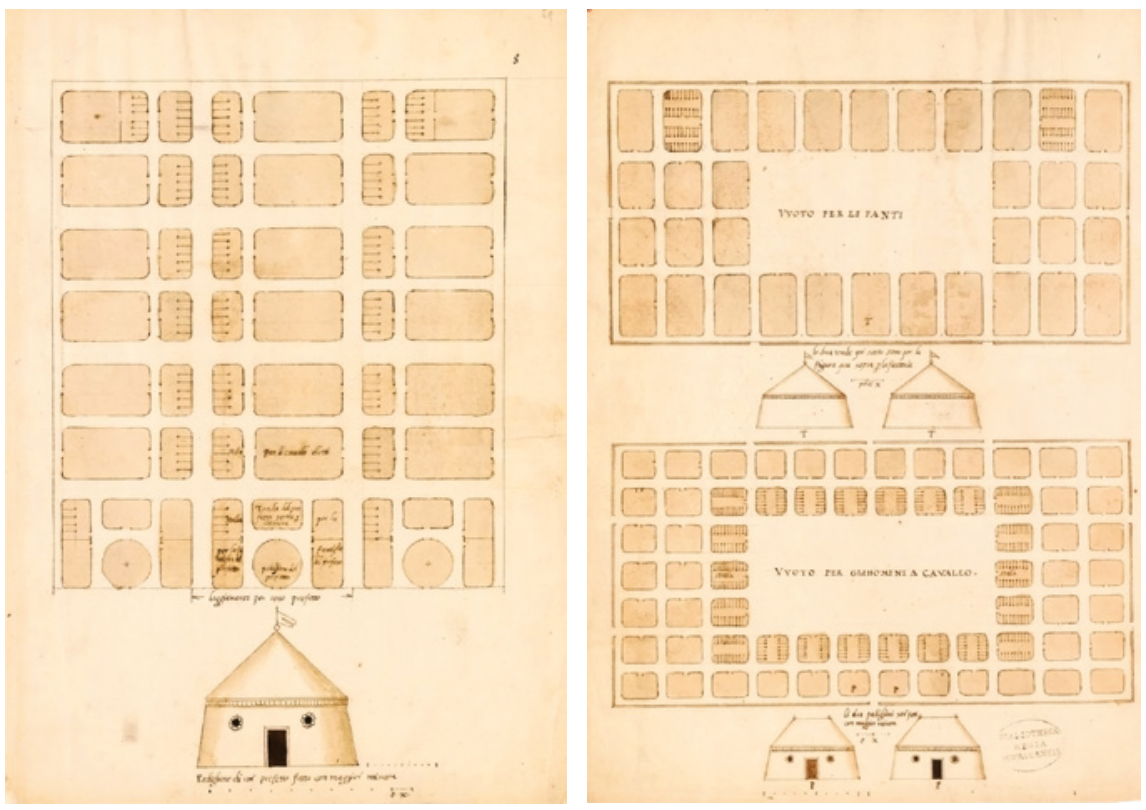

FIGURES $14.35-14.36$

Sebastiano Serlio, Castrametatio after Polybius, drawings in pen and wash showing his reconstructions of elements of the Roman military camp; Munich, Bayerisch Staatsbibliothek.

101 This detailed summary shows that Strada described an existing manuscript which unfortunately must have been lost afterwards; Theodor Mommsen and his colleagues of the Corpus Inscriptionum Latinarum were aware of Strada's description and made an unsuccessful search for the volumes. Only the Spanish inscriptions printed in Strada's 1575 edition of Caesar are included in the CIL, which also gives a succinct account of his antiquarian career (Hübner 1869, pp. IX-X). 
University Libraries of Vienna and Prague. ${ }^{102}$ Though Strada refers to the coins which he possessed either in the original or in the drawings he made of them in the cabinets of other collectors, it appears that this volume was not intended to be illustrated.

Iitem 7 was conceived as the visual component of this textual numismatic corpus: this was a book drawn in Strada's own hand on folio sheets each showing images of twelve coins and their reverses. These were chronologically ordered, beginning at Julius Caesar and ending with the ruling Emperor, Rudolf II. Compared to this, item 5 , which showed just one coin and its reverse preceding a brief life of each Emperor, should be considered as a luxury item directed at a more general public. As to its contents it can be compared to Strada's own Epitome thesauri antiquitatum, as to its appearance Strada probably envisaged something close to the beautifully executed volumes of Hubert Goltzius' Icones Imperatorum Romanorum, with their splendid chiaroscuro woodcuts [Figs. 14.33-14.34], rather than to Andreas Gessner's pirated folio edition of Strada's Epitome [Figs. 14.32 and above, Figs. 14.12-14.13].

Complementing these series of imperial effigies based on their coinage was a book illustrating their portraits from portrait busts preserved in Rome and elsewhere (item 6). This item can be related to the separate sets of drawings recently rediscovered in the Dresden Kupferstich-Kabinett [above, Ch. 13.7.1; Figs. 13.78 and 13.79-13.81]: though not identical, they give a good impression what it would have looked like. ${ }^{103}$ Classical sculpture was further represented in the sets of drawings of the friezes of the columns of Trajan (item 37) and of Marcus Aurelius (item 41) in Rome and of Theodosius in Constantinople (item 40), and possibly in item 36, drawings of 'all sorts of figures, reliefs, and ancient worked and carved sarcophagi and monuments [found] among the Roman, Neapolitan, Florentine, Venetian, Mantuan and other Italian peoples'. But since the phrasing of the latter description suggests the contemporary political situation rather than that of the Roman Empire, the chance is that these drawings represented or at least included medieval and contemporary funerary monuments, rather than ancient ones.

\footnotetext{
102 Vienna, Universitätsbibliothek, Ms. IIII-160898 [old shelfmark III 483]; Prague, University Library, Ms vir A 1. Two volumes of an unfinished version are preserved in Munich, BSBHS, Clm 163 and 164; cf. Jansen 1993(a), pp. 215-217 and 227-232.

103 SKD-KK, inv. nr. Ca 75: Imperatorum Romanorum ac eorum coniugum<...>; SKD-KK, inv. nr. Ca 76 (vol. I), Ca 77 (vol. II) and Ca 75 (vol. III): Series continuata omnium Imperatorum $<. . .>$; full titles given Ch. 13.7.1, notes 81-82; cf. Melzer 2010, pp. 130-138; Jansen / Metze 2018. Strada described his ideas for the illustrations of this item in his letter to Christophe Plantin, cf. below, Ch. 14.8 .
} 

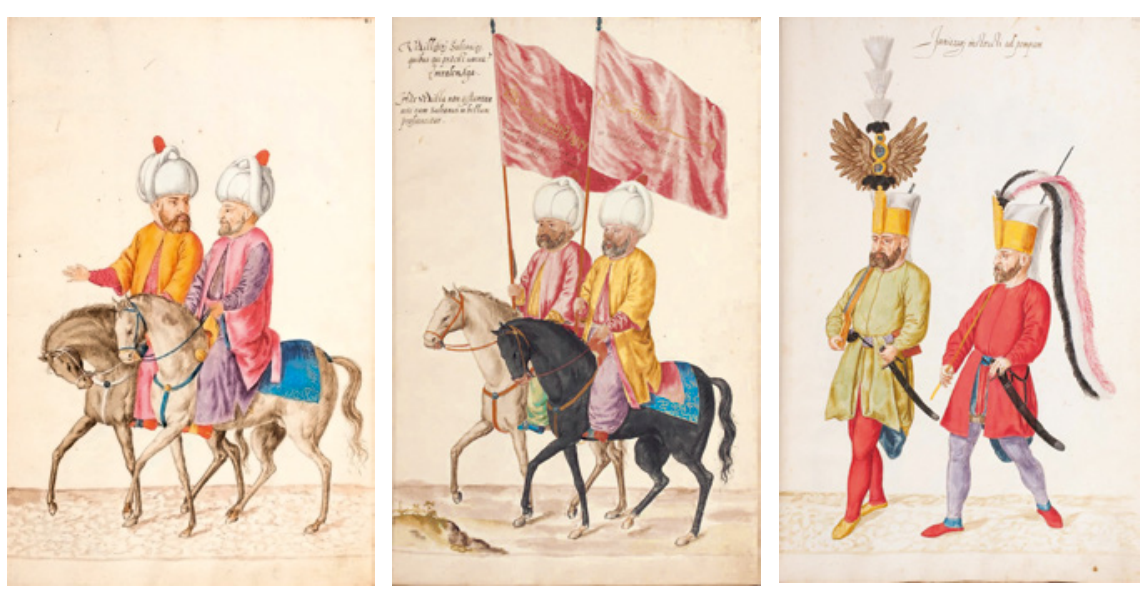

FIGURES $14.37-14.39$

Lambert de Vos, Images from his Kostümbuch, showing costumes and scenes from life in Ottoman Turkey; drawings in pen and ink and watercolours, 1574; Bremen, Staats- und Universitätsbibliothek.

Item 34, on the other hand, 'some books, drawn by hand, of buildings and architecture $<\ldots>$ which I myself have drawn after most ancient buildings, and have reduced as much as was possible to the same scale' probably was dedicated chiefly to (reconstructions of) ancient Roman monuments, though it may have included later buildings - such as Pisa Cathedral [above, Fig. 13.22] or the Florentine Baptistery — that at the time were considered antique or equivalent to the Antique.

Among the antiquarian works there are several with a military theme. The friezes of the three Columns of Trajan, Marcus Aurelius and Theodosius already mentioned are the principal examples, since these show military campaigns conducted by each of these Emperors: that of Trajan in particular is a mine of detailed information about the art of warfare as practised by the Romans. In this respect it is interesting that Strada intended to publish Giulio Romano's double frieze from the Camera degli Stucchi in the Palazzo del Te (item 14) not as a contemporary work of art, but as a complement to these three authentic friezes: he trusted Giulio's archaeological acumen sufficiently to consider it as an authoritative reconstruction of the manner in which Julius Caesar set out on his campaigns.

The same seems true of Sebastiano Serlio's reconstruction of the Castrametatio, the lay-out of the Roman military camp as described by Polybius and later writers. According to Strada, at the request of King Francis I Serlio had designed a huge plan (tabula) or reconstruction of this (item 12), and a companion piece in which Polybius' plan was adapted for the lay-out of a walled garrison 
town, which Francis intended to use for the construction of two fortified places on the borders with Piedmont and Flanders (item 13). These were really huge objects of nine feet square, indicating that both lay-out and individual sections - tents or army barracks - were shown in great detail. Some idea of its appearance can be had from the manuscript of Serlio's so-called 'Ottavo libro' in Munich [Figs. 14.35-14.36]. ${ }^{104}$ For Strada this still was not enough, since he explicitly commissioned Serlio to write a new book, which possibly may have been similar to the Munich manuscript (i.e. a description and illustration of a 'cittadella murata'), but more likely was meant to be a more scholarly reconstruction of Polybius' description (item 33). Strada stated that he had the woodblocks for this publication ready, in the same size-and doubtless commissioned at the same time and from the same artisans - as those used for his 1575 edition of the Settimo Libro. ${ }^{105}$

\subsubsection{The Ottoman Army}

Strada shared an interest in the military strategy and technique of the Ottoman Empire with many of his contemporaries. It seems a conscious parallel that next to the images documenting the battle order of the Roman Emperors as depicted in the Column of Trajan, Strada intended to print similar documentation of the manner in which the Sultan and his armies set out on their campaigns. He possessed two sets of documentation of this, both 'tabulae', the first of which had been reduced to a book format: this had been copied from a set of drawings which Antoine Escalin des Aimars, baron de la Garde, the legendary Capitaine Paulin or Polin, ambassador and admiral of the French king's galleys, had brought back from Constantinople as a gift for his sovereign (item 10).106

104 BSB-Hs, Cod icon. 19o; described by Marianne Reuter, 'Beschreibung der Handschrift Cod. icon. 190 Tresorhandschrift', in: BsB-CodIcon Online (Tue Jul 24 22:24:34 Cest 2012). It was published together with the Munich manuscript of the Sesto Libro and the Vienna manuscript of the Settimo Libro by Francesco Paolo Fiore and Tancredi Carrunchio (Serlio 1994).

105 Strada's manuscripts of these items are lost, as are the woodcuts he had made for item 33. Strada had also commissioned a set of woodcuts for the Sesto Libro, a set of proofs of which has been preserved in Vienna, which was published as an appendix to Rosenfeld's facsimile edition of the Avery manuscript. The Sesto Libro remained unpublished until Rosci's and Rosenfeld's facsimile editions of the two preserved manuscripts (Serlio/Rosci 1966; Serlio/Rosenfeld 1978). It is not mentioned in Strada's preserved correspondence and copyright privileges. Perhaps he abandoned its printing because of the damage to the woodblocks described in Ottavio's letter, perhaps he thought it not sufficiently diverse, and less practical than the Settimo Libro.

106 Antoine Escalin des Aimars, baron de la Garde-Adhémar, Marquis de Brégançon (1498?1578), was a général des galères generally known as 'le Capitaine Poulain' (or Polin or 
The second 'tabula' (item 11) was much more splendid, better drawn and showing more human figures and 'other things' than Escalin's version. It had been brought back to Vienna from Constantinople by Ogier Ghislain de Busbecq, Ferdinand and Maximilian's learned ambassador to the Sultan, who allowed Strada to copy it (as well as presenting him with countless ancient coins). Its style may have been similar to the famous Kostümbuch drawn in Constantinople by Lambert de Vos a few years later for Busbecq's successor, Karel Rijm [Fig. 14.37-14.39].107

Just as these drawings provided an Ottoman, contemporary parallel to those of the friezes of the Roman column monuments, Strada's documentation of the Roman castrametatio was mirrored by no less than three different tabulae documenting the manner in which the Turkish army encamped. The first of these (item 8) was based on a huge map of Suleiman's 1527 siege of Vienna in the Palazzo Ducale at Mantua, which Strada had borrowed from the Duke in order to have it copied in $1571 .^{108}$ The original was painted by an unnamed Flemish artist in gouache on canvas shortly after the event. It depicted the siege in great detail, paying particular attention to the various tents housing the Sultan himself, his Pashas and the captains of his Janissaries as well as to the actual topography of Vienna and its surrounding countryside. The second one (item 9) was not quite as magnificent as the first: it showed Suleiman's castrametatio in his wars against the Persians. This had been painted by 'some Frenchman who in Turkey had abjured the Christian faith', and it had been brought back from Constantinople by Strada's friend and patron, Bishop Antonius Verantius (Antun Vrančić), Busbecq's fellow ambassador. ${ }^{109}$ The third instance (item 39) consisted of two large images, the sheets of which were bound as a book, but its draughtsman and origin are defined no further. Finally item 28, a 'chronicle written in Arabic on [the history and/or the genealogy of] the Ottoman dynasty' is paralleled in item 19, Liber de familia illustrissimae domus Austriacae, on the history and the genealogy of the House of Austria.

Paulin); he was a protégé of the French soldier and writer Guillaume du Bellay, seigneur de Langey (and the subject of a sonnet by the latter's nephew Joachim du Bellay). He was François I's envoy to Suleiman the Magnificent in 1541. See Anselme De Sainte-Ange/Ange De Sainte-Rosalie 1733, pp. 929-930; Bouvier 2007. Strada also possessed a manuscript military treatise by Guillaume du Bellay, which may have reached him through the same agency (mentioned in his 1574 copyright privilege, Doc. 1574-05-30).

107 Bremen, University Library, Ms. Or 9; for a annotated facsimile edition, see Vos/Koch 1991. On Busbecq, see Von Martels 1989.

108 Cf. above, Ch. 9.7; Docs. 1571-03-19; 1571-11-20; 1577-10-04(a).

109 On Antun Vrančić and his connection with Strada, see above, Ch. 11.3. 


\subsubsection{Contemporary Art}

On his travels Strada had collected huge quantities of documentation, by direct purchase as well as by explicit commissions, both of antiquarian material-numismatics, inscriptions, sculptures, the remains of ancient monuments - and of contemporary achievements in the arts. Though the accent in his publishing programme is squarely on the antiquarian material, five items in the Index sive catalogus show that Strada did intend to publish some of the contemporary material as well. Two of these are collections of images of palaces and of monumental tombs respectively, found in Rome and in the principal Italian cities (items 35 and 36). We do not know what they looked like, but their description suggests a high-class type of coffee-table book, which could serve both as a souvenir for travellers and as a source of inspiration for patrons and the artists they employed. Their type is similar to the print series published from the mid-sixteenth century onward by Roman and Venetian printer's firms, such as Antonio Lafréry and Hieronymus Cock, mostly documenting the antiquities of Rome. Strada knew these series very well and they may well have served as his example for these two items. His interest in documenting contemporary monuments nevertheless seems a little out of the ordinary.

Two other items, however, are quite out of the ordinary: these are the complete reproduction of the entire decoration of Raphael's Loggia in Vatican Palace (item 42) and of the architecture and decoration of Giulio Romano's Palazzo del Te and of the apartments he designed in the Palazzo Ducale in Mantua (item 41). The lengthy descriptions in the Index indicate the value that Strada attached to these items, both of which were based on the reproduction drawings he had commissioned himself, and which have been discussed in greater
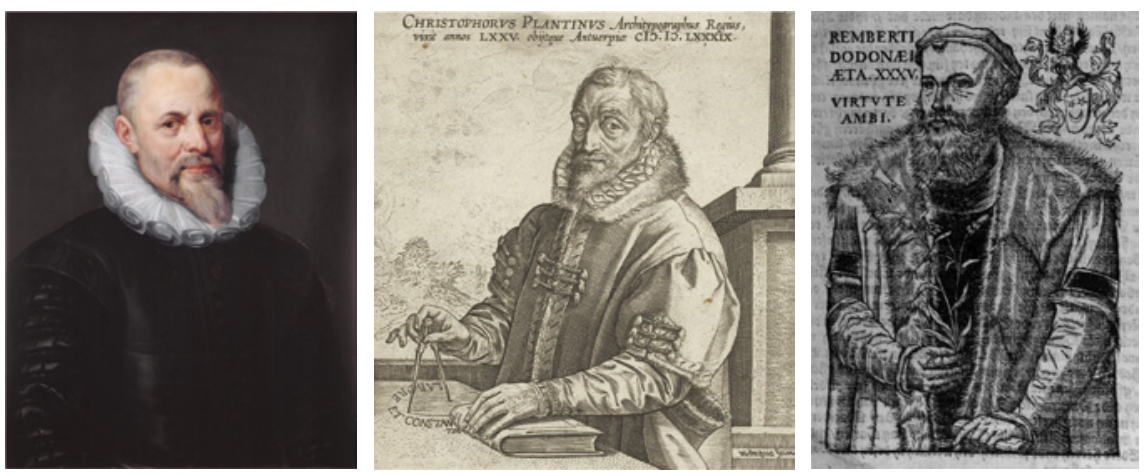

FIGURES 14.40-14.42

Jan I Moretus, here by Rubens, actually wrote the answer by Christophe Plantin (here by Hendrick Goltzius) to the letter Strada had sent him through Rembertus Dodonaeus, here in the portrait included in the first edition of his Cruijdeboeck (1554). 
detail above [Figs. 13.102-13.107].110 The project for the publication of such a detailed survey of a contemporary monument is rather unusual — a parallel is the print series by the Ghisi family of the Sistine Chapel ceiling — and Strada can be considered to be rather in advance of his time: the Loggia in its entirety was first reproduced in print only in the later eighteenth century.111

Much of the material intended to be used in these various volumes doubtless was likewise drawn upon for item 44: a hugely expanded, illustrated edition of Leandro Alberti's Descrittione di tutta Italia, which had first been published in Bologna in 1550. This was a project of long standing, since it had already been included in the copyright privilege Strada had obtained from Charles V. in January 1556 ; I will come back to it below. ${ }^{112}$

\subsubsection{Miscellaneous Materials}

In addition to the antiquarian material, the contemporary art and the Ottoman themes, the Index sive catalogus lists a few books in other fields, mostly rather succinctly described, which suggest that Strada included them for their rarity, their curiosity value, and perhaps for the supposed interest of some of his patrons, rather than out of any specific personal affinity. These include some esoteric works on magic, alchemy and divination:items 22 (Picatrix), 23 (Annulus Salomonis) and 24 (De geomantia liber). Items 29, 30 and 31, concerned with chronology, belonged together and consisted of an Arabic treatise on the fabrication of clocks and calendars, another Arabic calendar and a very carefully executed astrolabe and its tables. Item $3^{2}$ was another astrolabe, which came from Jerusalem, was therefore 'extremely old' and its inscriptions were all in Chaldean. Finally items 25, 26 and 28 were of a theological nature: item 26 was the Koran written in golden script already referred to, item 25 a Bible written in Arabic which Paolo Strada had brought with him from Constantinople, and item 48 a Greek genealogy of the Holy Virgin. Such miscellaneous items must have been included in the list primarily because of their curiosity value, a conclusion which is corroborated by the closing passage of the Index which refers to the many other beautiful and rare things Strada kept in his library and his Musaeum.

\footnotetext{
110 Above, Ch. 13.8.1.

111 In three series of prints engraved by Giovanni Volpato and Giovanni Ottaviani after designs by Giovanni Camporesi, Gaetano Savorelli and Luigio Teseo, published in Rome 1772-1776. On the prints of the Sistine ceiling: Moltedo 1991, pp. 68-79 (Last Judgment and Prophets and Sybils by Giorgio Ghisi) and pp. 80-97 (series of Ignudi, Sybils and Prophets and other figures by Adamo Scultori).

112 Below, Ch. 14.8; Doc. 1556-01-08.
} 


\subsection{Strada's Approach of Christophe Plantin}

Summarizing, one must conclude that, though Strada may have ultimately intended to publish all of the works listed in the Index sive catalogus, some of them were nevertheless closer to his heart than others. Moreover Strada was not completely destitute of a sense of reality, and in his less sanguine moments he realized that not all his projects were feasible. Thus in his letter to Grand Duke Francesco of Tuscany he showed that he knew that the printing even of the letter A only of his Dictionary really was a practical impossibility - though he continued to hope to have at least its indices printed. As we have seen, Strada had hoped the Grand Duke would himself undertake to have this and other items from his programme printed at Florence. ${ }^{113}$ At the Grand Duke's polite refusal, Strada decided to approach a professional publisher. Characteristically he opted for the biggest professional publisher in Europe: the Antwerp 'Archprinter' Christophe Plantin [Fig. 14.41].

Through his connection with the book trade Strada was well aware of Plantin's productions: thus when in 1573 he had requested Maximilian II to recommend his fundraising to print the letter A of his Dictionary, he had explicitly compared it with the concordances of Plantin's famous Polyglot Bible, which was just coming out at that time. ${ }^{114}$ When Rembertus Dodonaeus, the wellknown Flemish botanist, came to Vienna in 1574 to serve as Maximilian's physician [Fig. 14.42], he appears to have been sufficiently impressed by Strada's

113 Doc. 1577-10-04/d: 'Il mio Dictionario delle undeci lingue, ci è latina, grecha, hebrea, turcha, araba, persiana, spagnola, francese, tedescha et italiana. Questa si è fattica et spesa incredibile a chi non lo vede. Tutte queste lingue si parlano secondo le frases di Cicerone et altri huomini dotti; alli suoi lochi è posto le medaglie antiche, li marmi scritti, le statue, edifitii, et altre cose che sariano troppo longa matteria a volergli tutti nominare. La lettera A è scritta et sonno volumi 14; gli indici sonno volumi 18. Questi indici si potriano stampare, che secondo il calculo che sopra ne ò fatto sariano dui gran tomi simili a quelli del Thesaurus Linguae Latinae di Roberto Stefano di Paris; in questi indici vi sonno nominate tutte le cose che sonno al mondo di hogni genere. Ma la lettera A su nominata, questo saria impossibile a stamparla, ma si potria scrivere con dessignarvi le figure, et fargli ben legare in varii volumi, et porgli nella Sua libraria de Medici tanto famosa al mondo'.

114 Doc. 1573-00-oo: 'Questo Dictionario si trova adessa la lettera A al fine, e perchè, egli volendola far stampare, ci va grandissima spesa negl'intagli delle figure, le quali sonno medaglie antiche di hogni genere, et statue, inscriptioni, sepulture et altre cose, le quali sonno tutte ritratte da le vere antiquità, fedelmente et benissimo immitate, egli non si truova il modo del danaro di metterlo alla stampa. Et questa lettera A come sia stampata saranno parecchi tomi, o volumi, et sarra poco manco della Biblia Complutensi che in questo anno il Plantino à stampata in Anversa, la quale la Maestà del Serenissimo Re Catholico a sue spese et liberalità à fatto stampare'. In 1577 Strada proposed a selection from his programme to Francesco I (Docs. 1577-10-04/a and 1577-10-04/b). 
works to suggest him to offer at least some of them to Plantin, and to be willing to recommend them to the printer, a good friend and of course the publisher of his own famed Cruijdeboeck, one of Plantin's first, finest and most perennially popular editions.

At the time Strada did not avail himself of this offer, but once Dodonaeus had returned to Antwerp in March 1578, and Strada's other attempts to realize his ambitions had foundered, he wrote to Dodonaeus reminding him of his promise, and included a list of the books he asked Dodonaeus to present to Plantin. This list is an item by item paraphrase in Italian of the Index sive catalogus, and thus provided Plantin at one go with the entire publishing programme Strada had in mind, in case anything in it might appeal to his correspondent. ${ }^{115}$ But Strada singled out one item in which he thought Plantin might be particularly interested, and with which he himself had been strenuously occupied over the last year. This was an expanded, illustrated Latin edition of Leandro Alberti's Descrittione di tutta Italia, which had been first published in Italian in 1550, two years before its author's death. Though as item $\mathrm{nr} 44$ it comes relatively late in Strada's Index sive catalogus, it was nevertheless a project with which he had been involved for many years, since a Latin edition of the book is already mentioned in the copyright privilege Strada obtained from Charles V in 1556: that is ten years before the first Latin translation, by the humanist lawyer Wilhelm Kyriander, would actually be printed in Cologne. ${ }^{116}$

Strada appears to have continued collecting material to illustrate it ever since, but in 1577 he undertook a concerted effort to complete the appendices he envisaged. He wrote to the Dukes of Mantua and Ferrara, sketching his plans for the new edition in rosy colours and telling them exactly what materials he intended to add to the original version. For each region he intended to add a precise geographical map, as well as views of its principal cities and fortresses. For every city he also intended to add images of the principal monuments, 'that is, both the ancient buildings, and the modern, with their plans and elevations well measured'; then the ancient inscriptions 'drawn exactly as in they are in the marble, with the figures and ornaments that are found around them'. Moreover he wanted to add appendices with the names of the illustrious men of letters of each city and the works they had written; and finally

\footnotetext{
115 Doc. 1578-08-13.

116 On Leandro Alberti, cf. Redigonda 1960. The first edition of the Descrittione di tutta Italia was published in Bologna in 1550 . The Latin translation, Descriptio totius Italiae, was first published in Cologne 1566, and immediately reprinted. It might be worthwhile to investigate how much this translation, by the German scholar and lawyer Wilhelm Kyriander, may have or may not have owed to Strada's initiative. Strada intended to use Kyriander's translation in his own edition (cf. Doc 1584-12-05).
} 
the coats of arms of the Prince of each state, and of all its noble families. He asked both Dukes to help him collect this material, in particular the coats of arms of the local families and the profile views of the various cities of their dominions, "but taking care that the views are taken from a side from which they show well, and that they are drawn upon an open (= double) sheet of folio reale format or a little smaller.'17

Strada also asked both Dukes for further documentary material: he reminded Alfonso d'Este of an earlier promise to provide him with a copy of Giovanni Battista Pigna's History of the Este family of 1570, which he had never received. Strada asked Guglielmo Gonzaga for the loan of any similar information 'on the antiquities of your house' the Duke might have available in manuscript, to which he offered to add materials from his own collection. Moreover he listed

117 Both passages are almost literally the same; I cite the letter to the Duke of Mantua: 'Seremissimo Signor Ducha, sonno parech'anni ch'io pigliai nelle mani la Italia già descritta da Fra Leandro Alberti Bolognese, la quale lessi con hogni cura et diligenza, credendomi trovarvi tutte quelle cose ch'io dessideravo; ma mi trovai inganato. Le cose ch'io volevo che lui havesse messo erano queste: prima erano le cose che apartengono alla cosmographia, cioè che ad hogni regione vi fosse posta la sua mappa avanti alla sua descritione, et poi in quella regione vi fossero anche le figure di tutte le città pertinente ad essa regione, ben ritratte dal naturale. Ancora a cadauna città vi fossero le figure di tutte le cose più principale, come sarebe a dire gli edifitii antichi, et ancor li moderni, con le loro piante et profili ben misurati, con le sue misure scritte alli suoi lochi. Poi le inscriptioni antiche, che nei marmi vi si trovano ritratte a punto come stanno nei detti marmi, con le figure et altri ornamenti che anno d'intorno. Apresso la memoria di tutti gli huomini dotti con li loro nomi, con tutte le opere che loro hanno scritte, stampate e da stampare; ultimo tutte le arme, dico di cadauno Principe per cadauna città, cominciando alla prima della sua casa, et di mano in mano in sino a quella del Principe che hoggi vive; apresso a queste, quelle di tutti li nobili de cadauna città; et cossì havesse finito. Hora questo ordine su detto, che'l Frate a lassato fuori, io lo fo, et di già sonno tanto avanti che di essa prima Italia sudetta è accresciuta più delli doi terzi, et saranno tre gran volumi. A questo negotio son stato favorito et aiutato da molti Principi, con mandarmi dei dissegni che in essa mi bisognano. Dove non posso mancare ancora a Vostra Altezza di suplicarLa che quella si degni di farmi tal favore, cioè che Vostra Altezza sia contenta di farmi rittrare in dissegno le Sue città, cioè Mantova, Casale, Aich, Alba, et altre che à nel Monferato. Et ancora castelli dei più principali: sul Mantovano Vostra Altezza à dei castelli che paiono città, come Viadana, Cannedo, Gazolo et altri ch'io non mi riccordo; ancor questi li dessidraria, ma che sia pigliato la veduta da una qualche parte che si scoprino bene, et siano fatte sopra ad un folio reale aperto, o poco manco in circa. Apresso a esse vorei ancora le arme di esse casate nobile, cominciando prima a quella della città, et poi di mano in mano continouando come sopra ò detto [inserted in margin: dette arme siano collorite et picoline]. Suplisco Vostra Altezza che voglia comandare per la prima commodità che vi ponghi mano; et se in queste nostre parte vi sonno cose ancune che quella dessideri, solamente ne avisi qui al Signor Ambassador Suo che me ne acenni, che io subito gliene provedero; che altro non dessidero che servirLa come Suo buon vasallo et servidore'. 
the documentary drawings of the principal monuments of Mantua he had earlier obtained through Giovanni Battista Bertani, Giovanni Battista Scultori and Ippolito Andreasi, and now begged the Duke to help him obtain similar documentation on the decoration of the Palazzo Ducale and the Gonzaga villa at Marmirolo. As we have seen, the Duke appears to have honoured Strada's request, since Andreasi's drawings of the Palazzo Ducale were in fact executed and have been preserved together with those of the Palazzo del Te Strada had commissioned in $1567 .{ }^{118}$ Strada assured the Duke that there was nothing remarkable in his homeland ('patria') that he would not include in the book, and in particular as to architecture. But notwithstanding such chauvinism, it is hardly likely that he really intended to reproduce all of Andreasi's drawings in his edition of Alberti's Descrittione. For that book the elevations and plans of the principal monuments - similar to those of the Palazzo Pitti [above, Fig. 13.118-13.119] or the Duomo in Florence preserved in the Strahov Codex [above, Fig. 13.23] — would be sufficient, with possibly one or two of the most spectacular interiors (such as the Camera di Psiche or the Camera dei Giganti). On the other hand he did think that such material could be published as separate publications, as is clear from the descriptions of these sets of drawings and of those of Raphael's Vatican Loggia in the Index sive catalogus [items 41 and 42 ].

In his letter to Plantin Strada added some information about the practical aspects of his projected edition of Alberti's Description of Italy. Thus most of the views of the various cities were already engraved in wood or, if the blocks had not yet been cut, the designs had already been drawn directly onto the blocks for the engraver, in a uniform size similar to the small landscapes included in Strada's 1575 edition of Caesar's Commentaries [above, Fig. 14.2314.24]. He suggested that the maps of the individual regions, which should be of a larger size, could best be executed in copper engraving. Most of the coats of arms were already engraved, and the rest could be easily done in Antwerp, where there were far more and better engravers than in Vienna. It seems clear that in most cases Strada had drawn the models onto the woodblocks in person: at least that is what he offered to do for all the illustrations that had not yet been engraved, both for the Descrittione and for the other works he proposes to Plantin. For one other item, the illustrations of portrait busts of Emperors and their consorts, item 6 of the Index sive catalogus, Strada gave a practical suggestion: the portrait heads or busts themselves should be engraved in copper, but the pedestals for all could be printed from one woodblock, in which a space was kept open in which to compose the legends in letterpress; an impression of

118 Above, Ch. 13.8.2. 
what may have been his intention can be had from the similar Dresden manuscripts already mentioned [cf. above, Ch. 13.7.1, Figs. 13.78 and 13.79-13.81].

Apart from such practical insights, Strada's letter to Plantin gives a rare inkling of his approach to business. As his part of the deal he proposed to provide Plantin with a carefully edited manuscript of the Description of Italy and all the illustrations he had collected for it, both those he already had had engraved, and those he had merely drawn onto the woodblocks. But he expected Plantin to have engraved the remainder of the illustrations as well as to print as many copies of the book as he thought feasible, all entirely at his own expense, while Strada nevertheless laid claim to half of the profit once the books would start selling. He envisaged the same conditions for any of the other works in the list in which Plantin might be interested. In view of the doubtless considerable sums Strada had already invested in his various projects, this is not entirely unreasonable. But though not unreasonable, it is neither very realistic, in view of the huge investment Plantin would need to make should he agree to print such an ambitious book as the Description of Italy — for which at least a market can be assumed to have existed-let alone for the Indices to Strada's polyglot Dictionary, for which any potential market would have been restricted to the scholarly world.

So it is not surprising that Plantin's response was lukewarm at most. The draft of his reply was actually written by his son-in-law Jan Moretus [Fig. 14.40], who ran the Antwerp branch of the firm while Plantin himself managed the branch in Leiden, where he had been appointed printer to the newly founded University. ${ }^{119}$ Recognizing that Strada had brought together the manuscripts he proposed at great expense, Moretus first reacted to Strada's business proposition, stating quite clearly that Plantin was not used to pay for manuscripts of new books: his usual procedure was to let the author have one or two dozen copies of the book as printed. As an alternative the book could be printed entirely at the author's expense, in which case of course all copies and any eventual profit were his, rather than the printer's. Plantin's firm had never wanted to print books 'in compagnia', that is in a co-production between two or more investors sharing the eventual profit, which is basically what Strada proposed. Moretus explains that Strada is unreasonable in expecting the printer to bear all the expenses of the engraving of the illustrations and the printing of the book, and then still only allowing him half of the copies produced, 'which even when printed perhaps are not worth as much as the cost of the illustrations he

119 Doc. 1578-10-00: Jan Moretus' draft for the letter, which itself has not been preserved. 
had commissioned for it. ${ }^{\prime 20}$ He thinks Strada has not quite realized that the projects he proposed could only be printed by a very rich and 'curious' printer, 'more interested in having his drawers full of splendid typeface, than his cashbox full of money in order to be able to pay his employees'. Moretus does not mince his words, because he knows that Strada has experience with printing. He repeats that he will not acquire manuscripts for publishing against payment, and thinks that should not be done on principle, for if it is an author's ambition to bring his book to the attention of the public, he does not try to sell it for personal gain, "knowing in advance that [though] his pains will not be paid $<\ldots$.. his book will be a treasure for posterity'.

The general impression is that Moretus did not take Strada's proposal very seriously, though he was prepared to have any illustrations executed or to print any book that Strada wished, if at the latter's expense. And he did like the concept of the Description of Italy and was prepared to enter into negotiations about that, provided Strada would send him the text and all available illustrations - 'for one can form no judgment, or come to an agreement about a thing one has not seen'-and that he would delegate an agent with full powers to clinch a deal.

It is not known whether this letter actually reached Strada and whether he responded to it: there is no record of any further contact between Strada and Plantin. Strada doubtless did not intend to hand over his materials to Plantin merely in exchange for a few copies of the printed books, which would imply that he would almost entirely lose the considerable investments he had made over the years to compose the books listed in his Index sive catalogus, and to bring together the materials necessary to illustrate them in accordance with the high standards he had in mind. On the other hand he would not - probably could not-invest any further in the actual printing of even just a few of these books. With the death of Maximilian II and the consequent loss of Strada's privileged position at the Imperial court, there was moreover little stimulus for other princes or magnates to help Strada's projects by providing financial assistance. So it is not surprising that Strada, besides attempting to interest Plantin in his venture, engaged in the various futile efforts to raise money for his projects which have been described above, such as the lottery of his house and collection.

120 But is should be noted that Strada had not asked for half of the copies printed, but for half of the profit actually realized, that is, after costs, which is something rather different. 


\subsection{The Rupture with Ottavio}

But it was not only Maximilian's death which frustrated Strada's ambitions. Another factor was the rupture, probably about a year later, with his son Ottavio, who, as we have seen, was instrumental both in the actual production of the books, and in the collecting of the subventions Strada obtained from at least some of his patrons. It is not clear when exactly this rupture occurred: it can be assumed that it was preceded by a period of increasing irritation, which doubtless was mutual. Relations were still harmonious when Strada conveyed greetings of both Paolo and Ottavio to Jacopo Dani in June 1576, and informs him of their careers in October 1577. Ottavio is not mentioned, however, in the letter to Plantin-when he would have been the obvious gobetween, having earlier travelled to the Southern Netherlands on behalf of his father's projects - and in Strada's letter to Dani of 1581 no mention is made of him either. ${ }^{121}$

By 1584, when Strada drew up his last will, the rupture was definitive and irreversible: Strada almost entirely disinherited his second son, in favour of his elder son Paolo and his young, legitimized son Tobia. ${ }^{22}$ The reasons for this take up a huge portion of the document: Strada charges Ottavio with no less than sixteen alleged offenses and crimes, accusations which-even if only half of them were true-indeed provide ample justification for Strada's decision. They range from simple embezzlements, through theft and fraud, to personal aggressions which suggest a pathological, almost oedipal hatred of his father: Ottavio's rape and attempted murder of his father's mistress certainly is extremely shocking. ${ }^{123}$ When Archduke Ernest had presented Strada with an excellent palfrey, Ottavio had wilfully ruined the horse and wounded and insulted Strada's faithful servant; and when his father once in Prague had upbraided him for his wayward behaviour, he had became so angry that he began tearing up a book belonging to the Emperor, in which he was prevented only

121 Docs. 1576-06-16: 'Pauolo et Ottavio, mei figliuoli, salutano la Signoria Vostra per centomilia volte'; 1577-10-04(c): 'Et alla Signoria Vostra io con li mei figliuoli salutiamo Vostra Signoria per sempre. Ottavio sta con Sua Maestà Cesarea et Pauolo con l'Arciducha Hernest, si che tutti doi sono ancora servidori della Signoria Vostra, et io insieme'; 1581-11-02: 'Et qui fo fine, salutando la Signoria Vostra con tutto il cuore, alla quali quanto posso io con Pauolo mio figliuolo di cuore vi dessideriamo hogni fellicità et longa vita'. Of course by this time Ottavio probably resided in Prague with Rudolf II, but even then it might have been expected that Strada would have informed his old Florentine friend of his son's career move.

122 Doc.1584-07-01, transcribed in Appendix B.

123 Ibidem, point 12. 
by the intervention of his sister and brother-in-law; Strada even felt that, had Ottavio had had a dagger at hand, he would have been attacked in person. For these reasons Strada even suspected his son of a plot to have him assassinated together with his mistress and his elder son Paolo.

Obviously something had gone very, very wrong between father and son. On the one hand Ottavio may have reacted unkindly to the low-born servant who replaced his late mother in his father's affections. ${ }^{124}$ On his part the elder Strada may not have easily brooked the fact that Ottavio appeared to have taken over his position with Rudolf II, who largely ignored the elder Strada. What at most can be said is that Strada very likely exaggerated Ottavio's crimes, and that his own authoritarian and uncompromising behaviour may have contributed to his son's rebellion. Yet there can be no doubt that Ottavio's behaviour towards his father, if not criminal, at least was reprehensible and possibly inexcusable.

Some of Ottavio's transgressions were in fact criminal in nature, such as when, on two occasions, he forged his father's signature in order to obtain money from his business associates. Even worse, when he pocketed the proceeds of the two books he had had printed in Frankfurt at his father's expense, he not only made out a false document stating that his father had made over these proceeds to him, but also spread the report that his father had died, which caused Strada endless trouble with the local magistrate to have himself acknowledged when arriving in Frankfurt in person. Or such as when Ottavio stole directly from his father's Musaeum: not only hundred ducats' worth of high quality Venetian paper, which he sold at his own profit to a local bookbinder, but also a beautiful clock, the masterpiece of the famous engineer Hans Gasteiger which had been a gift from Duke Albrecht v of Bavaria, and even part of Strada's famous collection of Roman Imperial coins and some of his best drawings, which Ottavio likewise sold for his own benefit. ${ }^{125}$

Some of Ottavio's 'crimes' were directly related to his acting as his father's agent, and may have been his business decisions with which his father did not agree-perhaps even only in hindsight. When he claims that Ottavio had collected the subventions accorded by Elector August of Saxony and had kept these for himself, we cannot be certain that Ottavio did not invest them at least in part in the projects he was managing for his father. ${ }^{126}$ Moreover, when Strada reproached him to have spent money without his father's knowledge

124 Ibidem, points 3 and 5: Ottavio's stole thirteen golden rings with precious stones from his mother's chest after her death; cut off the pearls and the golden buttons and other ornaments from his mother's clothes and hats and took some ready money. He had opened the chest by means of a key he had previously stolen from his father's safety box, of which he had obtained a forged key.

125 Ibidem, points 2 and 9, point 4, points 6, 7 and 8 .

126 Ibidem, point 1. 
and approval on the woodcuts for a series of 'Mummereij Stuckh', costumes designs for masques, tournaments and other court festivities, and for similar woodcuts for an illustrated Bible, which he planned to sell for his own profit, he is less than straightforward, for both these projects were in fact discussed in Ottavio's letter to his father of December 1574, and in terms which clearly demonstrate that Strada at least initially did not disapprove of them. ${ }^{127}$

From this letter to his father it is clear that Ottavio was very much aware of the commercial side of the enterprise, probably much more than Jacopo himself. Ottavio's antagonism may to some extent be the effect of growing irritation at the unrealistic ambitions and ideals of his father, which threatened to absorb a huge part of the patrimony of his family without much prospect of any immediate profit, and of Strada perhaps not sufficiently acknowledging his son's serious efforts and initiatives to make their business prosper.

We shall never know the real causes of the clash between father and sonbut we can easily deduce at least two of its effects on the success of Strada's projects. The first is that Strada now lacked a trusted, competent and energetic assistant and agent to help organize, manage and supervise the production of the books, to negotiate with printers, draughtsmen, engravers and booksellers and to represent him with sponsors and business partners. Strada's faithful elder son, Paolo Strada, who had been ordained a priest, lacked the interest in his father's projects as well as the necessary energy and business acumen, whereas Strada's habitual business partners in Nuremberg and Frankfurt, such as the Nieri, would lack the necessary expertise.

The second effect, probably of equal importance, is that Ottavio's shady dealings - in particular his forging of his father's signature to letters of exchange and his spreading the rumour that his father had died —-must have damaged Strada's credit with all but his closest associates. So Strada's failure to bring out any other books after 1575 was due at least in part to Ottavio's defection.

\subsection{Strada's Testamentary Disposition}

Strada's several attempts to raise money must be considered in the light of his increasing despair of realizing his ambition to realize even only part of his publishing programme. We have already seen how his plan to make a lottery of his

127 Ibidem, point 15; compare this with Ottavio's report to his father, Doc. 1574-12-05 (in Appendix A), passim, containing many references to his expenditure on behalf of the illustarted Bible, the 'libro delle mascare' and a German translation of the Serlio volume. With his will Strada enclosed and referred to the receipt given by Jost Amman for the advance Ottavio had paid him for the woodcuts of these 'mascare'; cf. above, Ch.4.3.5.; O’Dell 1990. 
possessions was frustrated by unwilling authorities in Vienna. He continued to try and find a purchaser for his collections. Thus early in 1581 he negotiated about the sale of a part of his library with Šebestián Freytag z Čepiroh, a former tutor of Rudolf II. Since 1573 the learned Freytag was abbot of the Premonstratensian monastery of Louka (Klosterbruck) near Znojmo in Moravia, where he had instituted a college and established a printing press. He was eager to acquire the books of which Strada had sent him a survey, but it is not known whether they came to an agreement - if so, the abbey acquired only a part of Strada's holdings, because his attempts to sell the remainder would continue almost until his death. ${ }^{128}$

But even if these efforts had concrete results-which we do not knowthese were not sufficient to allow Strada to realize his dreams within his lifetime. So he decided to provide for his project in his will or testament. The first version of this he made up in the spring of 1584 in Brno, where he had been carried after he had fallen seriously ill when employed at nearby Bučovice in Moravia by Jan Šembera Černohorsky z Boskovic. ${ }^{29}$ Since his property was mostly found in Vienna, he first tried to have the testament registered and guaranteed by the government of Lower Austria as well. In the end, however, he opted for a new version made up on the first of July of the same year: an imposing document held together by a splendid string of parti-coloured silk, and provided with the seals of Strada and the three witnesses. ${ }^{130}$

After the usual preliminaries Strada expressed the wish that, should he die in Vienna, he was to be buried in the Franciscan Church 'ad Sanctam Crucem', that is the Minoritenkirche, the church closest to his own house. Then he began listing the legacies to his mistress, his servant, his young bastard daughter Sicilia and his two legitimate daughters and their children, none of whom got very much. His surviving daughter Lavina got only 100 Gulden, not only because she had already been given her dowry, but also 'because she never shows any loyalty or kindness to me': which indicates that Ottavio was not the only

128 Docs. 1581-01-01 and 1581-02-03. It is not known whether a final agreement was reached. Perhaps the Strada volume in the Library of Premonstratensian monastery of Strahov in Prague arrived there from Louka (which was dissolved in the late eighteenth century).

129 Doc. 1584-04-30: 'wie daß ich itzundt ettliche Monadte lang im Landt zu Mähren, bei dem Wolgebornen herren herren Hansem Schembre fon Tschernahor und Bosskowitz, auf Budtschovitz etc. meiner geschäfte halben gewesen, und nach dem [ingevoegd: ich] zu Budtschovitz mit krankheit uberfallen und beladen, habe ich mich von dan in die stadt Brijn führen lassen $<\ldots$..'.

130 Doc. 1584-07-01, fully transcribed in Appendix B. The witnesses were Sebastian Hartman, Strada's 'Schwager' (so either the husband of a sister of his wife or the husband of one of his own sisters); Adam Eberman, a civil servant, accountant at the Kammer (chamber of accounts) of Lower Austria, and Joseph Lamparter, owner of a 'Hoftaverne' in Vienna. 
one of his children who had a bad relationship with their father. ${ }^{131}$ Though Ottavio, next mentioned in the document, likewise was given a small legacy of fifty Rhenish Gulden, Strada explicitly excluded him from any further share in his inheritance, and then began summing up the list of his crimes which has already been referred above. Then he reiterated his intention to disinherit Ottavio entirely, underlined that Ottavio should have no power to challenge Paolo's and Tobia's legacies, and begged the local authorities to ensure that his children be protected against Ottavio's possible pretensions and that his will be executed to the letter.

After this follows the most astonishing clause in this extraordinary document: Strada stipulated that all the manuscripts from his library that were listed in the attached survey - this is a fair copy of the Index sive catalogusshould be handed over to his legitimized son Tobia, 'because my legitimate son Paul has no interest in them'. Tobia-or rather the trustees that were to be appointed for him, for at this time Tobia was at most seven years oldwere to have these printed without delay by Strada's printer at Frankfurt. To finance this, Strada had already instructed and authorized Paolo to execute a deed of gift immediately after his death, donating his entire Musaeum to a predetermined recipient. This gift should include both the library and the Kunstkammer, but of course it excluded the manuscripts listed in the Index sive catalogus: together with the illustrations-drawings, woodblocks and engraved plates-belonging to them, these should be placed under seal immediately after Strada's death. Tantalizingly the intended recipient was not identified, but it must have been a rich and powerful prince- such as the Emperor, the Elector of Saxony or the Duke of Bavaria—if Strada thought the gift he expected in return would be amply sufficient to pay for the printing. ${ }^{132}$

It is then only that Strada finally arrived at actually bestowing his remaining property, his 'houses and gardens, together with all moveable goods, and the cash value of all assets due to him, both in writing and otherwise'. After due

131 Ibidem. It should be noted that Lavina in fact gets the biggest of these preliminary legacies. Strada's housekeeper and mistress, Margaretha Hummerin, merely gets her wages for the seven years she had lived with him and her clothes, and an extra legacy of only ten Gulden. His servant Christoph Sartor from Rosenheim got likewise ten Gulden. His young illegitimate daughter Sicilia was to receive a legacy of hundred Gulden when she came of age, and until that time was to be dressed from the interest of that sum. The two daughters of his late legitimate daughter Anna, who had both already taken religious orders, got twenty-five Gulden each. Strada's testament makes it quite clear that he made a strict distinction between his children born within and out of wedlock (perhaps also in recognition of his legitimate children's rights in respect of their mother's inheritance?)

132 In fact Strada assigns half of these proceeds to Paolo himself, while the other half should be made available to Tobia's trustees to finance the printing. 
settlement of his debts, all this was to be divided unequally between Paolo and Tobia: the legitimate elder son Paolo should get two thirds, the legitimized younger son Tobia one-third. He moreover instituted them as each other's heirs in case of their dying without issue and intestate. Strada also reserved the rents of his real estate, or a part of its proceeds if sold, for Tobia's maintenance and education, stipulating however that in case any considerable surplus might remain, this would be used toward the printing of his books. The value he attached to this is moreover attested by his demand that Paolo would use all the donations received in exchange for the dedications of the works already published towards the printing of the remainder. ${ }^{133}$

All this suggests that his printing project was of greater importance to Strada than the future prosperity of his heirs. This is borne out by another odd stipulation in the will: should Tobia die before the proceeds from the presentation of Strada's Musaeum would have materialized, his trustees should nevertheless use both Tobia's legacy and his share in any forthcoming presents to undertake the printing programme, 'in order that the labour and industry with which I wrote these books will not be in vain because the books remained unprinted'. Though Strada did envisage that the trustees would be paid for their trouble, it seems likely that it would be difficult to find trustees able and willing to take on that task. ${ }^{134}$

\subsection{Conclusion: The Aftermath}

The clauses in Strada's will obliging his heirs to finally print his books indicate the immense value he attached to his publication project, an importance far transcending any possible profit he initially may have expected from it. It is clear that by this time he considered this as his life's work, his contribution to posterity, and he devoted the larger part of the last years of his life to it. It is difficult to judge in how far Strada had any confidence that his heirs would want and be able to execute his rather unrealistic last wishes; certainly he never ceased attempting to realize at least part of his programme within his lifetime. Just a few months after he made his will Strada obtained from Emperor Rudolf II a new copyright privilege for a number of the works mentioned in the Index sive catalogus:

133 Ibidem. Since the last books Strada had published had come out in 1575, this last stipulation must refer to books he was planning to publish at the time he was writing his will.

134 Ibidem; no trustees are appointed in the will, perhaps indicating that Strada as yet had found no one willing to shoulder that responsibility. 
- a series of the Roman Emperors, their consorts and other relatives illustrated by their coins (Index sive catalogus, item 49)

- the seven volumes of inscriptions (item 3 )

- Strada's collection of descriptions of all ancient coins he had studied (item 4), accompanied by another voluminous volume of numismatic drawings of all ancient rulers, including those of Rome (item 5)

- the battle order of the Romans and their castrametatio according to Polybius (item 12);

- Photius' Biblioteca (item 21)

- the expanded Latin edition of Leandro Alberti's Description of Italy (item 44)

- an edition of Wolfgang Lazius twelve books of comments on the history of the Provinces of the Roman Empire (item 46)

- and finally the biography of the Emperor Charles $\mathrm{v}$ illustrated by a huge number of coins and medals documenting his reign (item 18). 135

When Strada again offered his house for sale two years later, he explained that it was inconvenient for him to live in Vienna, because he had a task in hand which took up much of his time, for a prolonged period. It seems reasonable to assume that he referred to a planned absence in Nuremberg or Frankfurt to work on his books, to have their illustrations engraved, and to manage their printing, though it is not known whether he did in fact leave Vienna. ${ }^{136}$

To raise the necessary funds for his projects Strada remained eager to convert at least some of his possessions in ready cash. Thus his contacts in early summer of 1585 with Václav Březan, the archivist, librarian and historiographer of the Rožmberk family, indicates that he made a last effort to sell part of his collection to his old patron. ${ }^{137}$ When this attempt miscarried, he asked the Landmarschall (Lord-lieutenant) of Lower Austria, Hans Wilhelm von Roggendorf, to offer his house and his collections for sale to the members of the local

135 The descriptions do not always match those in the Index exactly. The most interesting item in the privilege is the A.A.A. numismatwn $\triangle I A \Sigma K E N H N$, hoc est Chaldaeorum, Arabum, Lybicorum, Graecorum, Hetruscorum ac Macedoniae, Asiae, Syriae, Aegypti, Syculorum, Latinorum seu Romanroum regum a primordio urbis, dein consulum<... >tam sub caesaribus $<\ldots$. imperatoribus $<\ldots>$ metallicarum iconum explicationum, the title and description of which largely corresponds to Strada's manuscripts volumes of coin descriptions, sets of which are preserved in Vienna and Prague.

${ }_{13} 6$ Strada's request of 3 December 1586 to the Landmarschall of Lower Austria: 'weillen mir aber andere gelegenhait fürfallen, das ich alhie zue wonnen mir ungelegensamb ist, dann ich ain werckh underhandten, darzue ich vill und lange zeit bedarff' (Doc. 1586-03-12). His departure may have been conditional on the sale of the house, which did not materialize, or another financial windfall.

137 For (the concept of) the letter by Březan, see Doc. 1585-06-02. 
nobility who were to attend an impending meeting of the duchy's Estates, but again this appears not to have met with any success. ${ }^{138}$ Perhaps for that reason he contemplated selling his smaller house in the suburb of St Ulrich, the house in which he actually lived: that at least seems the most plausible explanation for his request, a few months before his death, to the Chamber of accounts of Lower Austria, to delegate some of the Emperor's 'Pauleute' in Viennaprobably an architect, a master-mason and one or two relevant craftsmen - to provide an estimate of the value of that house. ${ }^{139}$ It is clear that most or all of Strada's efforts to obtain funding were in vain, because none of the books mentioned in this last copyright privilege or in the Index sive catalogus had been published under his name or imprint by the time he died in the autumn of 1588.140

In view of the complicated testament, which was certain to lead to litigation, Strada's studio was put under seal pending the opening of the will..$^{141}$ The reading of the will took place in the presence of a representative of the Landmarschall only on 28 September 1590: almost two years after Strada's death! The family was represented by Paolo Strada, also representing his half-brother and -sister who were still under age, and by Ottavio. Even before that, Ottavio had already commenced contesting the will, as is evident from his reference in

${ }_{13} 8$ Doc. 1586-03-12, request presented to the Landmarschall in person. Members of the Austrian nobility were the most obvious potential buyers of the house: as a Freihaus its ownership was nominally restricted to noblemen and to ecclesiastical institutions.

139 Doc. 1588-02-18, request to the Niederösterreichische Kammer, which was conceded.

140 Strada died on or around September 6 of 1588, according to a letter from Ottavio Strada to Alfonso II d'Este, Duke of Ferrara, dated from Prague, the 26th of that month: 'Non o anche potuto mancare di avisar V.A.S. come mio padre che era Antiquario di S.M.C. et servidor di V.A. è morto fra 20 giorni, iddio gli dia pace al anima sua'. (Doc 1588-09-26). Contrary to an implication in Straka 1916, p. 21, followed by Lietzmann 1997, p. 394, the letter does not mention the place of Strada's decease and there is no reason to assume that Strada died elsewhere than in Vienna. Lietzmann's hypothesis that Strada would have reconciled himself with Ottavio, moved to Prague and made a new testament is not only unlikely, but expressly contradicted by the fact that the 1584 testament was put into execution, by Ottavio's litigation with his brother Paolo, and by his references to objects kept in his father's studio in Vienna to which he had no access (cf. below). Ottavio announced his father's death in a similar letter to Belisario Vinta, secretary of Grand Duke Ferdinando I of Tuscany, Prague 6 December 1588: 'Questa è sola per salutar la S.V. molto ill.re et offerirgli li mei servicij, con avisarla come sonno alcune settimane che morì il mio padre, che stato Antiquario di questa Augustissima Casa, già 38 anni, el quel è stato affectionatissimo servidor di quella, et grand amico' (ASF, Medici del Principato 810, f. 129).

141 Ottavio Strada to Belisario Vinta, secretary of Grand Duke Ferdinando I of Tuscany, Prague 10 April 1590, writing about some books of drawings of his father's: '...et molte volte S.M.C. mi fa domandare de questi libri, dove sempre trovo scusa che sonno in Vienna nel studio serratij...' (ASF, Medici del Principato 814, f. 343). 
a letter of June 1590 to 'la mia lite che tengo qui a Vienna contra mio fratello', which had caused him to come to Vienna. ${ }^{142}$

In view of Ottavio's trusted relationship with Emperor Rudolf II, of his daughter Anna Maria's liaison with Rudolf, and doubtless also because of the eccentricity of Strada's testament, it is not surprising that the litigation was resolved in an agreement between Ottavio and his siblings which granted him a much more considerable share than his father had allotted to him. ${ }^{143}$ This share even included manuscripts included in the Index sive catalogus, since shortly after his return to Prague Ottavio offered two of these, the beautiful Bible in Arabic, and the stupendous Koran written in golden script, to Grand Duke Ferdinando I of Tuscany, supplying some additional information on their provenance. Likewise the Series of Roman Emperors and Empresses offered to Ferdinando may well have been the original manuscript of item 49 of the Index sive catalogus. ${ }^{144}$ To Duke Alfonso II of Ferrara Ottavio offered a manuscript of the Genealogy of the House of Austria, which he claimed had been finished by his father only two months before his death. ${ }^{145}$ In January Ottavio presented

142 Ottavio Strada to Ferdinando I, Grand Duke of Tuscany, Vienna 17 June 1590 (ASF, Medici del Principato 817 , f. 72 ).

143 The copy of the testament preserved in öNB-Hs, Cod. 8079) carries a note 'die Vergleichung der Bruedern und Schwestern vide in S<eguito?>'. Unfortunately that document has not been preserved.

144 Ottavio Strada to Belisario Vinta, secretary of Grand Duke Ferdinando I of Tuscany, Prague 20 October 1590: 'A presso gli do aviso come ho portato meco da Vienna in qua una Bibia Araba in folio scritto a mano et un Alcorano medesimamente scritto d'lettere d'oro in Arabo, che dui simil libri mai siano venuti di simil qualita in questi parti $<. . .>$ Mio padre bona memoria sempre ha ricercato di haver nel suo studio qualche cosa non comuna, et con gran faticha et spesa a messo insieme simil cose. La Bibia a costato in Constantinopoli 50 ducati; per signale il Exc. Carlo Rim, ambassiador di S.M.C. compro tal libro a nome di mio padre. Del Alcorano non so il pretio; Sua Altezza segli piacevano me dia quello che vuole, saro contento'. (ASF, Medici del Principato 822, f. 885). Idem, Prague 6 December 1588 (ASF, Medici del Principato 810, fol. 129:): 'Il mio padre ha lassiato un bellissimo studio, con belissimi libri scritti de Antiquita et Medaglie, et fra la altri ha descritto una Continuata Series de Imperadori, della loro vita et gesti, cominciando da Julio Ces[are] insino al Imperador presente, et posti le loro medaglie a quelli che si poteva trovare, per avanti da niuno mai stato tal faticha, et essendo la ultima opera da lui fatta, et ancora da niuna vista'.

145 Ottavio to the Duke of Ferrara, Doc. 1588-o9-26: 'Ha fatto fra le altre opere sue, un arbore della Geonologia [sic] del origine della Casa de Austria, et ridotto in un libro della medesima grandezza come quello che mandai a V.A.S. et ha posti le arme loro in tempo in tempo come solevano portare, con li ritratti loro, et in chi sonni stati maritati, cusí anche delle donne, opera finita da lui dui mesi avanti che morse, et da niuna ancora visto, s' V.A.S. desiderara di vederla, comandi qui al S.or Florio, che io gli consignaro, et V.A. me usara piacendoli l'opera, quella gratia che gli parera $<\ldots>$ '. 
Elector Christian I of Saxony with three albums containing drawings of busts of 'the Roman and Greek (= Byzantine) Emperors up to Constantine XV, who lost Constantinople. ${ }^{146} \mathrm{He}$ claimed that he had taken them from his late father's Kunstkammer in Vienna, and that they 'were my father's last work, that he has made with his own hand', but since Ottavio at that time did not have access to his father's cabinet, he must have brought these drawings in his possession much earlier; they are still preserved in the Kupferstichkabinett in Dresden in the original red satin bindings. ${ }^{147}$

Also Paolo Strada disposed of some of the material he had inherited in a similar way, offering two volumes of his own continuation of the six books of numismatic drawings his father had earlier provided to Maximilian II to the Imperial librarian Hugo Blotius in 1592, together with the large map of the 1529 Siege of Vienna by the Turks, item nr 8 in the Index sive catalogus. In 1594 he offered some architectural models and a list of books from his father's library to Landgrave Moritz of Hessen-Kassel. ${ }^{148}$

All this strongly suggests that Strada's wish to have his books printed posthumously was tacitly or explicitly ignored by his heirs. For this one can hardly blame them, since Strada's disposition cannot have been realistic and would have been impossible to carry out in any case. Certainly none of the books listed in the Index sive catalogus were printed in that form, and no other books were published indicating their provenance 'ex Musaeo Jacobi de Stradae'.

Nevertheless this does not mean that his material may not have found channels by which it still could be of use, and some of it may actually have been published in other books; since much of it was not actually composed by Strada himself, its provenance would not necessarily have been indicated. It would, for instance, not be surprising if some of Strada's lexicographical materials had ended up with the Hebraist Elias Hutter, who shared Strada's linguistic interests, had visited him in Vienna and had recommended his labours to his own patron, Elector August of Saxony. Thus Hutter's Dictionarium harmonicum biblicum, ebraeum, graecum, latinum, germanicum, printed in Nuremberg in 1598, may well owe something to Strada's earlier labours [Fig. 14.43-14.44], as may Hutter's scholarly polyglot Bible editions [Fig. 14.45].

In a similar manner it is unlikely that the woodblocks commissioned by Strada to illustrate his various books would never have been used for other prints. Thus some of the scenes in Sigmund Feyerabend's many illustrated

\footnotetext{
146 HStAD 10024, Loc. 8543/1, fol. 159r; cf. Melzer 2010, p. 135; Jansen/Metze (forthcoming).

147 SKD-KK, Ca $75^{-77}$.

148 Hugo Blotius to Wolfgang Rumpff, Vienna, 18 March 1592, ÖNB-Hs, Series Nova 363, ff. 159-16o; Paolo Strada to Moritz Landgrave of Hessen-Kassel, Vienna 23 December 1594, Marburg, Hessisches Staatsarchiv, Bestand 4n, nr. 265.
} 

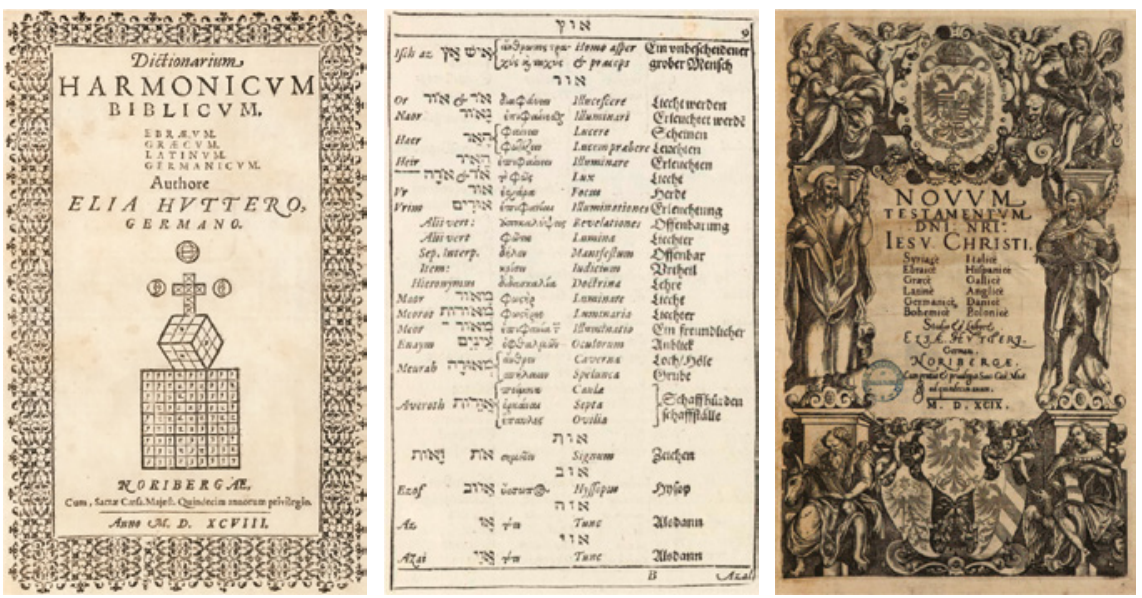

FIGURES $14.43-14.44$

Elias Hutter, Dictionarium harmonicum biblicum, Nuremberg 1598, title page and p. 9 .

FIGURE 14.45

Elias Hutter's polyglot edition of the New Testament, in Hebrew, Greek, Latin, Syrian, Italian, Spanish, French, German, Danish, Czech and Polish, printed in Nuremberg in 1599, title page.

Bible editions may derive from those Strada planned to have cut by Jost Amman after Giovanni Battista Scultori's designs; and some of Amman's illustrations for the unfinished book of Mummereyen, festival costumes, were in fact printed and sold as separate sheets or series [above, Figs. 4.23-4.25]. Finally Strada's own descendants, his son Ottavio and his grandson, Ottavio Strada the Younger, brought out several publications based on Jacopo's work or on the materials he had collected.

Ironically, it was Ottavio who in his De Vitis Imperatorum et Caesarum Romanorum and in his Genealogia et series Austriae Ducum, Archiducum, Regum et Imperatorum realized at least part of two of the works listed in Strada's Index sive catalogus (items 7 and 19). The first of these, a series of lives of the Roman emperors accompanied by images of their coinage, was posthumously printed in 1615 in Frankfurt at the expense of the publisher Laurentius Francus [Fig. 14.47-14.48], and in 1618 in a German translation by Ottavio's own son Ottavio Strada von Rosberg the Younger [Fig. 14.46]. Both versions were reprinted by Eberhard Kiefer in Frankfurt in 1629, together with the second work, a Latin genealogy of the Habsburg dynasty, which itself many years later was reprinted in Leiden in 1664. It can be assumed that both works given to Ottavio were largely based on his father's manuscripts; yet since Ottavio probably extensively collaborated on these in his youth, he cannot be blamed for wishing to garner some laurels by them. 

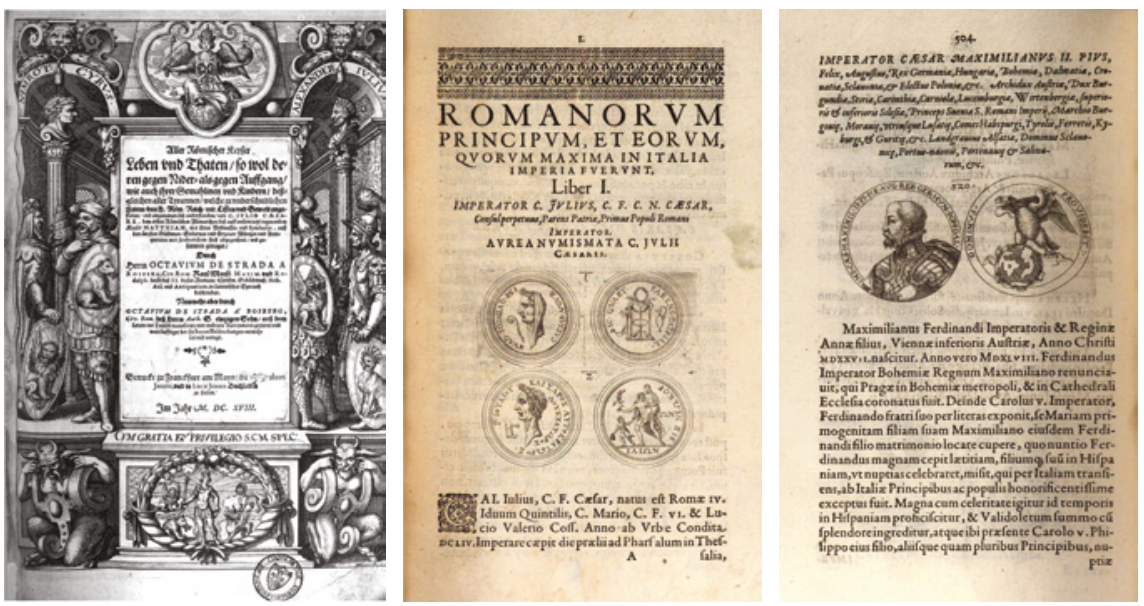

FIGURE 14.46

Ottavio Strada, Aller römischer Kayser Leben und Thaten, Frankfurt a.M. 1618 , title page.

FIGURES 14.47-14.48 Ottavio Strada, De Vitis Imperatorum et Caesarum Romanorum,

Frankfurt a.M. 1615, opening page of the chapter on Julius Caesar and the entry on Emperor Maximilian II.

Even more ironically, the only volume that was published under Strada's own name after his death concerned a subject in which he himself apparently was not particularly interested. This was a set of technical drawings for wind-, waterand treadmills, fountains and pumps and other inventions largely derived from the technical tradition stemming from Francesco di Giorgio Martini. Though an autograph manuscript of this in Strada's hand exists [Fig. 14.49], this material — which he doubtless obtained at least in part with Serlio's collection-figures in none of the written sources, and was certainly never included in Strada's publishing programme (though Ottavio the Elder provided manuscript sets to various of his own patrons). ${ }^{149}$ Ottavio the Younger published it in a Latin, a German and a French edition [Figs. 14.50-14.51], probably both because of his own personal interest, and as a means to draw the attention of potential patrons to his professional competence as a hydraulic engineer.

Entering into a partnership with the largely Dutch company charged by Henri IV already in 1499 with the draining of the marshes in various regions of France, this competence allowed him to re-establish the fortune of his family, after his forced departure from Bohemia after the Battle of the White Mountain: as Marquis de Strada d'Arosberg his descendants became the biggest

149 On this treatise, see the facsimile edition of one of the copies by Ottavio the Elder, now in the Museo delle Scienze in Florence: Marchis/Dolza 2002. 


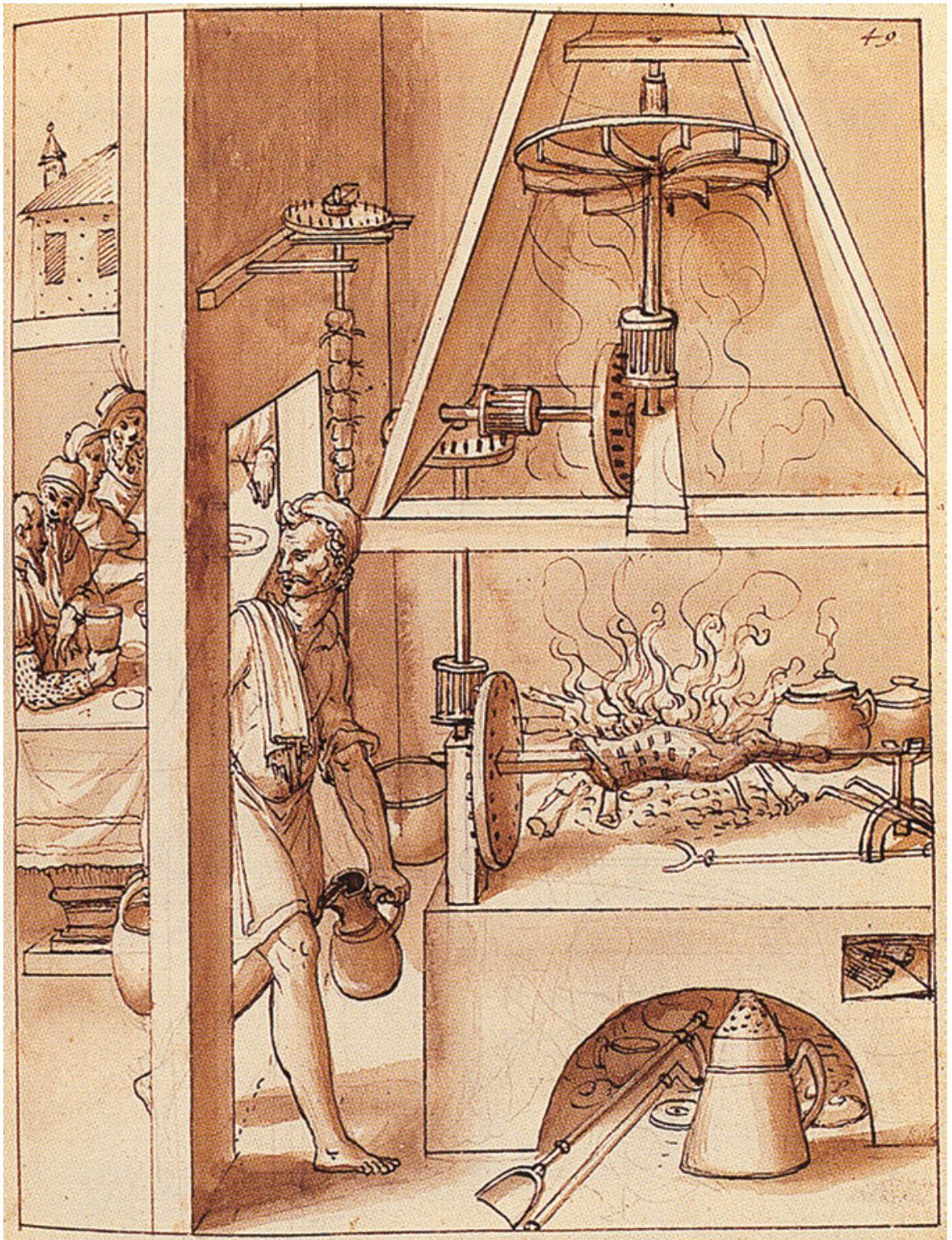

FIGURE 14.49

Jacopo Strada, design for a contraption automatically turning a spit, drawing in pen, ink and wash in his ms Variae ac faciles molendinae construendi inventiones (Codex Clavreuil), present location unknown. 

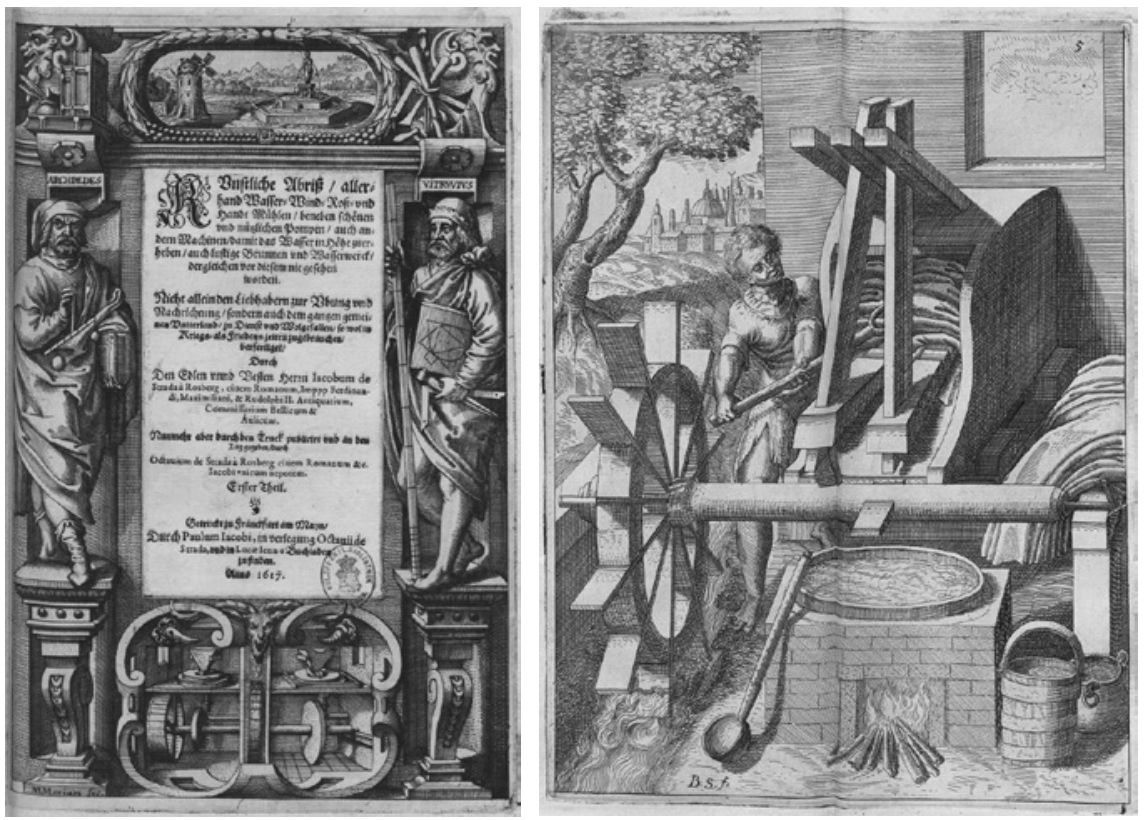

FIGURES $14.50-14.51$

Jacopo Strada, Künstliche Abriß / allerhand Wasser-, Wind-, Roß, und Handt mühlen, Frankfurt a.M. 1617, titlepage and design for a water-driven fulling mill.

landowners in Auvergne [Fig. 14.52].150 The extraordinary design of a tower of the small castle he had built at Sarliève, near Cournon in Auvergne, a former lake which had been drained by his efforts, shows that he at least had profited by the study of whatever materials from his grandfather's Musaeum he still may have possessed [Figs. 14.53-14.54].

150 Pascuito 1978, pp. 73-81; 'Strada d'Arosberg' is a manifest misreading of 'Strada da Rosberg'. A recent genealogy (Chabot D'Allier 1990) sketches the ramifications of the Strada family, which include the still surviving male line, as well as a President of the French Republic, Valéry Giscard d'Estaing. On the compagnie that drained the French marshes, see Comte De Dienne (himself a Strada descendant), Histoire du dessèchement des lacs et marais en France avant 1789 (Dienne 1891), passim and esp. pp. 382-389; and the articles by Thomas daCosta Kaufman and Dirk Jansen in Marchis/Dolza 2002. I am indebted to $\mathrm{M}$. and Mme Yves Chabot de l'Allier for a very pleasant and informative conversation on Strada's descendants. 

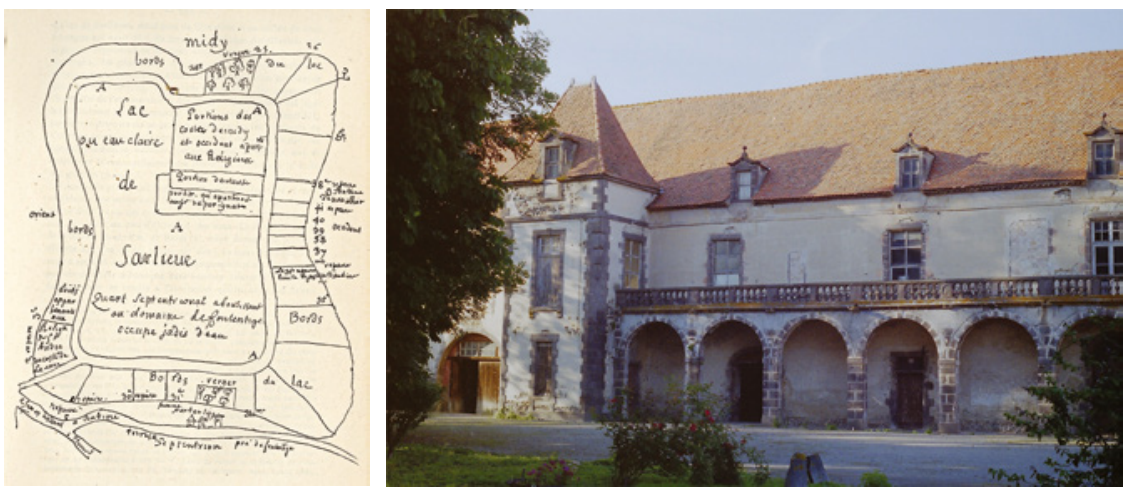

FIGURE 14.52

Sketch of the Lac de Sarliève as drained under supervision of Ottavio Strada the Younger, made in connection with a lawsuit in the late seventeenth century.

FIGURES 14.53-14.54 The small château built at the domaine of Sarliève, built for (and designed by?) Ottavio Strada the Younger, ca 1640-1650.

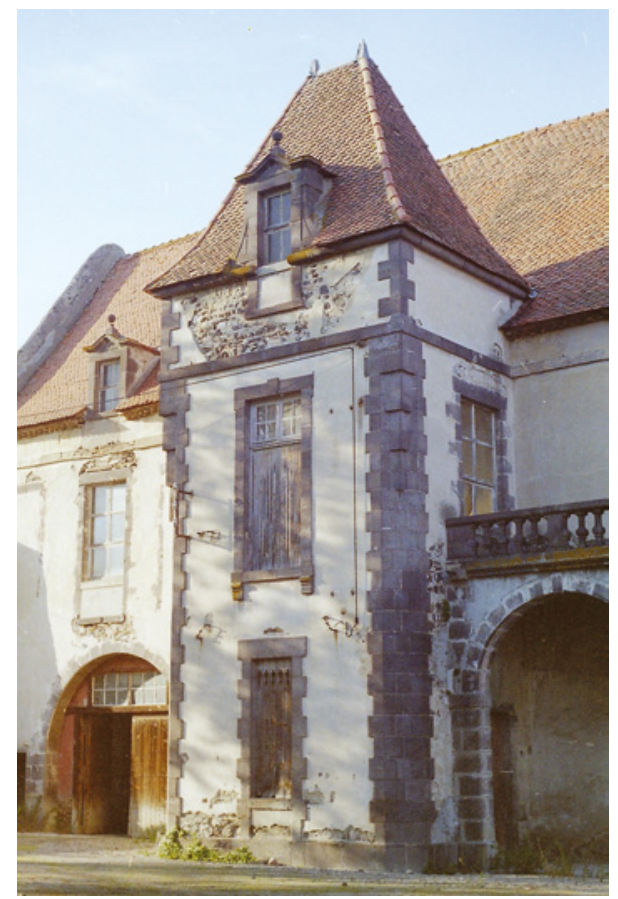

